UNIVERSIDADE DE SÃO PAULO

INSTITUTO DE GEOCIENNCIAS

\title{
DEFINIÇÃO DE CARACTERÍSTICAS DO MEIO FÍSICO PARA IMPLANTAÇÃO DE ATERROS SANITÁRIOS NA PORÇÃO SUL DO MUNICÍPIO DE PARANAGUÁ
}

Emerson Carneiro Camargo

Orientador: Prof. Dr. Uriel Duarte

TESE DE DOUTORAMENTO

Programa de Pós-Graduação em Recursos Minerais e Hidrogeologia 


\section{UNIVERSIDADE DE SÃO PAULO \\ INSTITUTO DE GEOCIENCIAS}

\section{DEFINIÇÃO DE CARACTERÍSTICAS DO MEIO FÍSICO PARA IMPLANTAÇÃO DE ATERROS SANITÁRIOS NA PORÇÃO SUL DO MUNICÍPIO DE PARANAGUÁ}

Emerson Carneiro Camargo

Orientador: Prof. Dr. Uriel Duarte

TESE DE DOUTORAMENTO

COMISSÃO JULGADORA

nome

Presidente :

Examinadores:
Uriel Duarte

Alberto Pacheco

Luis Enrique SAnchez

Mônica Lopes Gonçalves

André V.L.Bittencourt ass.

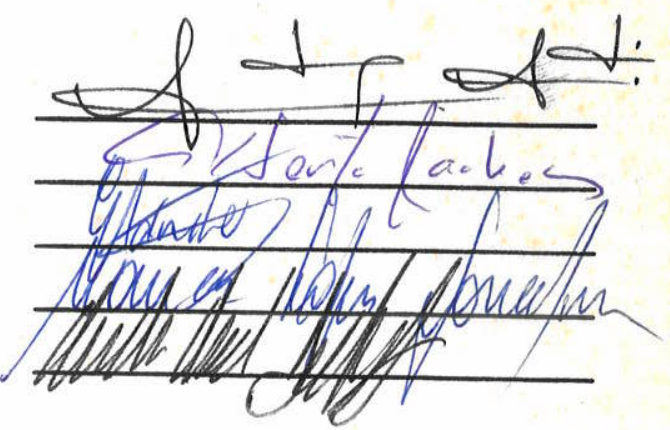




\section{UNIVERSIDADE DE SÃO PAULO \\ INSTITUTO DE GEOCIENCIAS}

\section{DEFINIÇÃO DE CARACTERÍSTICAS DO MEIO FÍSICO PARA IMPLANTAÇÃO DE ATERROS SANITÁRIOS NA PORÇÃO SUL DO MUNICÍPIO DE PARANAGUÁ}

Emerson Carneiro Camargo

Orientador: Prof. Dr. Uriel Duarte

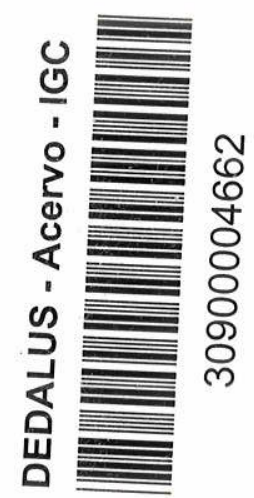

TESE DE DOUTORAMENTO

Programa de Pós-Graduação em Recursos Minerais e Hidrogeologia

T2163

São Paulo 1995 
A Uricena Guimarães Carneiro in memorian 


\section{AGRADECIMENTOS}

Os mais sinceros agradecimentos ao Prof. Dr. Uriel Duarte pelo incentivo, orientação segura e objetiva.

Ao Prof. Dr. Alberto pacheco (I.G.-USP) cujos conselhos ajudaram a estabelecer os objetivos deste trabalho.

Ao Prof. Dr. Helio Olympio da Rocha (Depto de solos - UFPR) pelas discussões sobre os solos, acompanhamento no campo e permissão de uso do laboratório de Eotopedologia e Interpretação de Imagens do Depto de Solos do Setor de Ciências Agrárias da UFPR.

Ao Prof. Dr. Valmiqui Costa Lima (Depto de Solos - UFPR) pelas discussões que esclareceram pontos importantes sobre os solos da região estudada.

Ao Prof. Paulo Cesar Krelling (Depto de Geociencias - UFPR) pelo acompanhamento no campo e auxilio nas fotografias.

Ao Prof. Luis Cláudio de Paula Souza (Universidade Estadual de Ponta Grossa) pelo acompanhamento no campo e ajuda na coleta de amostras de solos.

A Luis Bertotti (pós-graduando em Agronomia - S.C.A.-UEPR) pela colaboração na digitação dos mapas.

Ao Setor de Ciências Agrárias - UFPR pelas análises granulométricas e de p.H. dos solos realizadas no laboratório de solos.

Ao Departamento de Estradas e Rodagem - PR pelas análises dos solos executadas na Divisão de Pesquisa e Desenvolvimento.

Ao desenhista do Depto de Geologia Oto Laurentino Rosa, pelos esmerados desenhos que acompanham este trabalho. 
A bibliotecária Eliane Maria stroparo pelo auxilio com as referencias bibliográficas, e por permitir livre acesso aos períodicos da Biblioteca do setor de Tecnologia da U.F.PR.

A todas as demais pessoas que incentivaram e ajudaram na realização deste trabalho. 


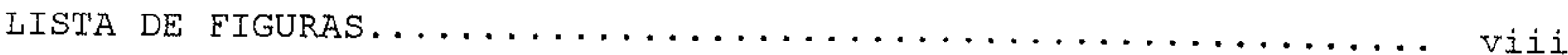

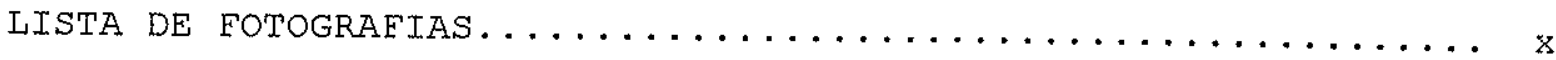

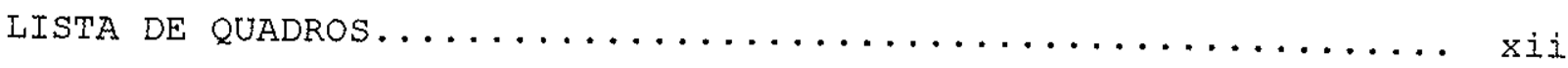

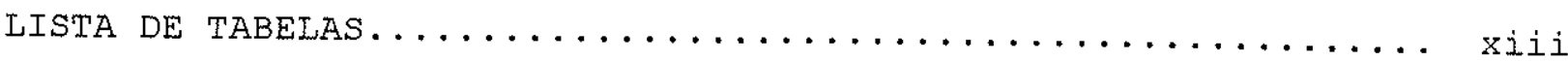

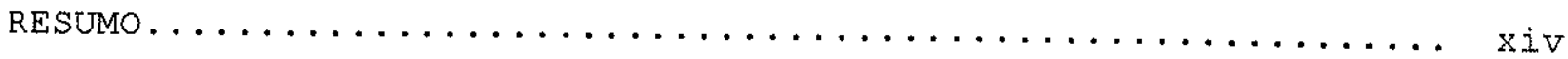

ABSTRACT $\ldots \ldots \ldots \ldots \ldots \ldots \ldots \ldots \ldots \ldots \ldots \ldots \ldots \ldots \ldots \ldots \ldots \ldots \ldots \ldots$

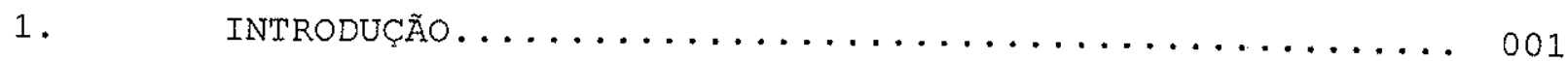

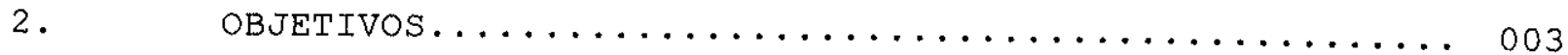

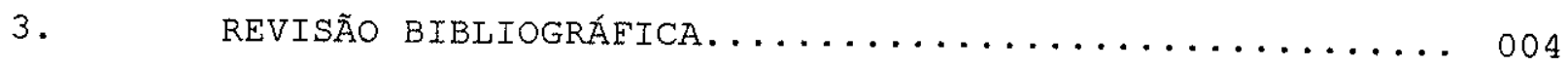

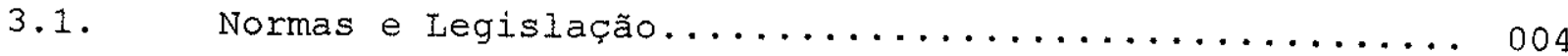

3.2. Caracterização do Meio físico................ 006

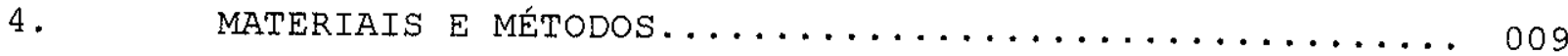

4.1. Materiais.......................... 009

4.1.1. Localização Limites e Acessos................... 009

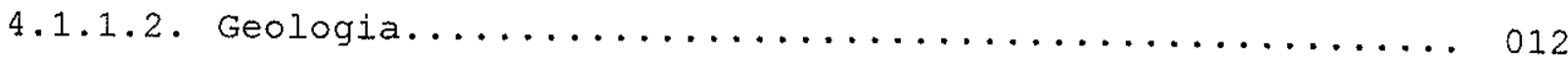

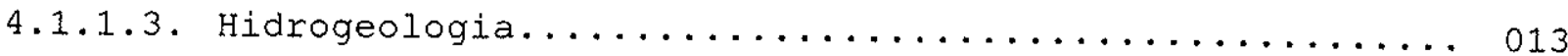

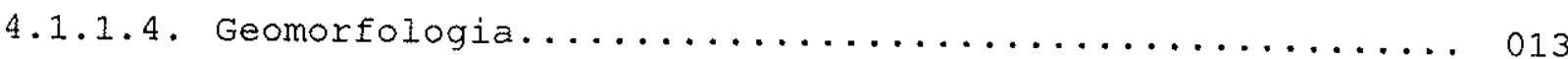

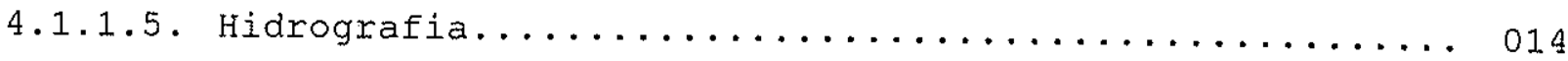

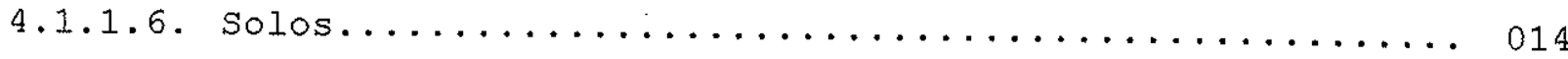

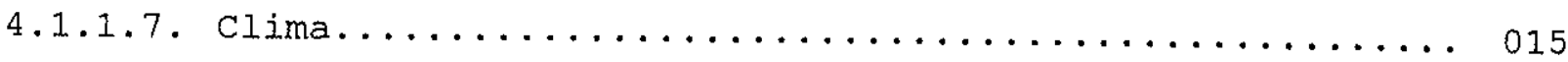

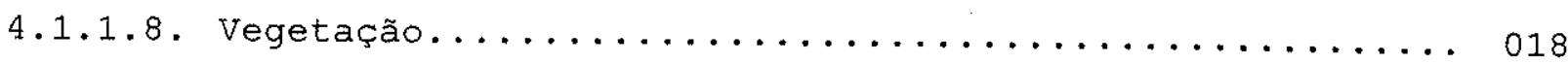

4.2. Métodos........................... 020

4.2.1. Métodos de Campo....................... 020

4.2.1.1. Mapeamento Geológico.................... 020

4.2 .1 .2 . Mapeamento Geomorfológico................... 020

4.2.1.3. Levantamento do Nível Potenciométrico........... 021

4.2 .1 .4 . Levantamento Geofísico.................. 021

4.2.1.5. Descrição de Perfis e Coleta de Amostras de Solo..... 022

4.2.2. Métodos de Laboratório.................... 023 
4.2 .2 .1$. Análise Granulométrica dos solos............... 023

4.2.2.2. Análise da Plasticidade dos solos............... 023

4.2.2.3. Análise da Permeabilidade dos solos............. 024

4.2 .2 .4 . Análise do p.H. dos solos.................. 028

4.2.3. Classificação dos solos.................. 028

4.2.4. Cartografia........................ 030

4.2.4.1. Mapa Potenciométrico.................. 030

4.2.4.2. Mapa de Vulnerabilidade dos Aqüíferos............ 030

4.2.4.3. Mapa de Classes de Declividade................ 031

4.2.4.4. Mapa de Caracterização das Áreas para a Implantação de

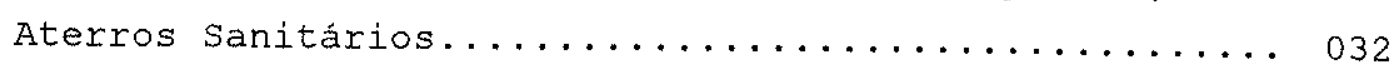

4.2.4.5. Digitalização dos Mapas.................. 032

4.2.5. Método de Avaliação da situação Atual da Disposição dos Resíduos sólidos Urbanos em Paranaguá.......... 033

4.2.6. Método de Avaliação das Áreas Adequadas para a Implantação de Aterros Sanitários................. 034

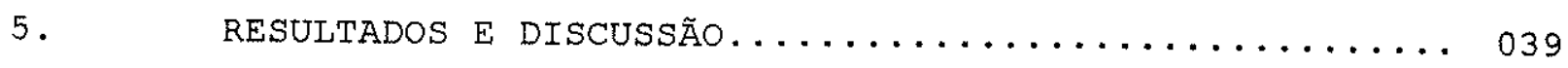

5.1. Análise da Situação Atual da Disposição dos Resíduos Sólidos em Paranaguá.................... 039

5.1.1. Levantamento da Qualidade, Quantidade e Classificação dos Resíduos sólidos Produzidos................ 040

5.1.2. Os Depósitos de Resíduos sólidos do Município de Paranaguá............................. 044

5.1.2.1. O Depósito de Lixo da Ilha de Valadares............ 047

5.1 .2 .2 . O Depósito de Lixo de Alexandra-Matinhos........... 051

5.1 .2 .3$. o Depósito de Iixo de Embocuí................ 058

5.1 .2 .4 . O Depósito de Lixo de Shangrilá................ 064

5.2. Avaliação da Área em estudo para a Locação de Aterros

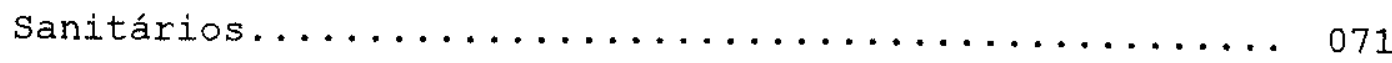

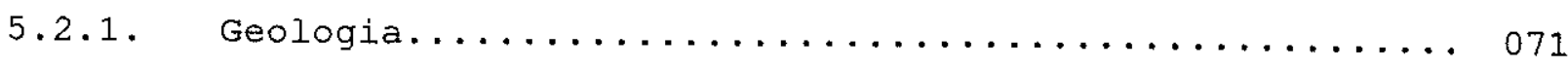

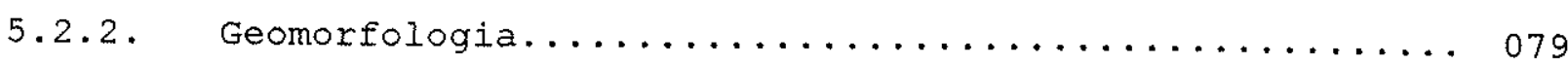

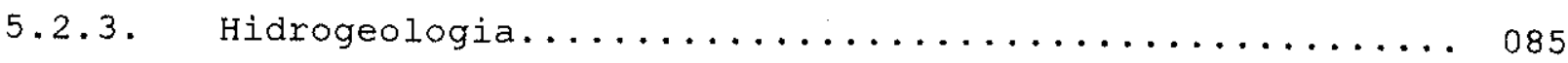

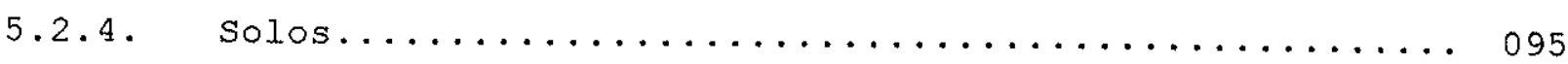

5.3. Caracterização das áreas para a implantação de aterros Sanitários............................ 103 


\section{ANEXOS}

ANEXO 1 - Mapa geológico da porção sul do município de Paranaguá - Escala - 1:50.000..........
ANEXO 2 - Mapa de superficies geomórficas da porção sul do município de Paranaguá Escala - 1:50.000.

ANEXO 3 - Mapa de classes de declive da porção sul do município de Paranaguá - Escala - 1:50.000..

ANEXO 4 - Mapa potenciométrico da porção sul do município de Paranaguá - Escala - 1:50.000....

ANEXO 5 - Mapa de vulnerabilidade da porção sul do município de Paranaguá - Escala - 1:50.000..

ANEXo 6 - Mapa de solos da porção sul do município de Paranaguá - Escala - 1:50.000..........

ANEXO 7 - Mapa de caracterização das áreas para implan tação de aterros sanitários da porção sul do município de Paranaguá - Escala - 1:50.000.. 


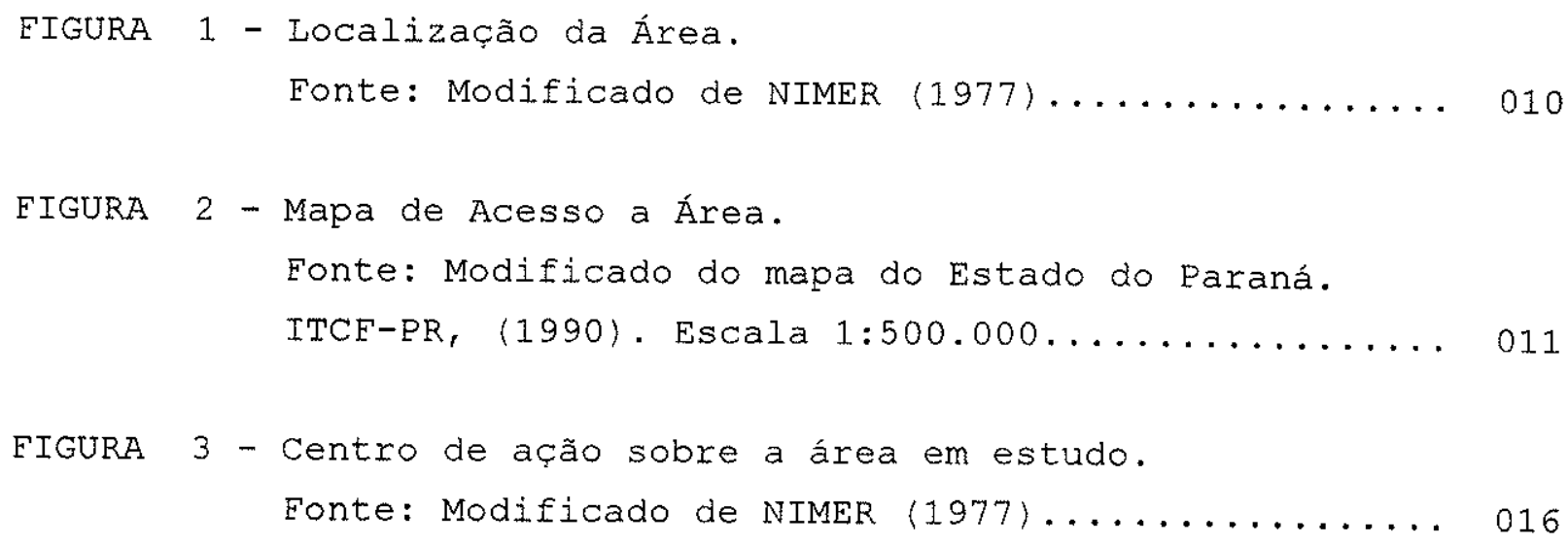


pág.

FIGURA 11 - Mapa de localização do depósito de lixo de Shangrilá........................... 065

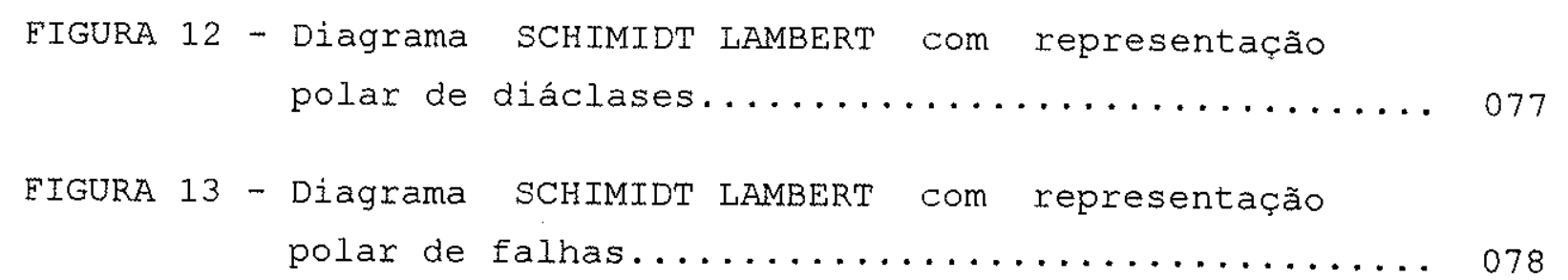


EOTOGRAFIA 1 - Flagrante de um morador jogando lixo no depósito da ilha de valadares............. 049

FOTOGRAFIA 2 - Ocorrência de afloramentos de áqua junto com - lixo na ilha de valadares.............. 050

FOTOGRAFIA 3 - Concentração de água no depósito hospitalar, após chuvas excessivas............... 054

FOTOGRAFIA 4 - Flagrante de descarregamento do lixo hospitalar no depósito de lixo de Alexandra-Matinhos..... 056

FOTOGRAFIA 5 - Foto mostrando seringas descartáveis, agulhas e outros materiais u sados em hospitais, que causam risco de contaminação no depósito de lixo de Alexandra-Matinhos............. 057

FOTOGRAFIA 6 - Loteamento situado nos arredores e em cima do depósito de Iixo de Embocuí........... 060

EOTOGRAEIA 7 - Exposição do chorume proveniente da parte mais antiga do depósito de lixo de Embocuí....... 062

FOTOGRAFIA 8 - Ação dos catadores e dos urubus no depósito de lixo de Embocuí..................... 063

FOTOGRAFIA 9 - Trecho de difícil tráfego na estrada secundária de acesso ao depósito de lixo de Shangrilá.... 066

FOTOGRAFIA 10 - Exposição do lençol freático no depósito de Shangrilá..................... 067 
pág.

$\begin{aligned} \text { FOTOGRAFIA } 1.1 \text { - } & \text { Foto mostrando um catador fazendo reciclagem } \\ & \text { do lixo, separando papelão, latas e vidros no } \\ & \text { depósito de lixo de Shangrilá.............. } 070\end{aligned}$ 
LISTA DE QUADROS

pág.

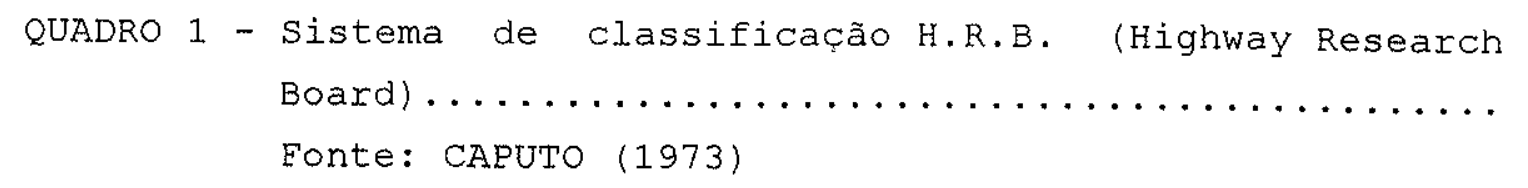

QUADRO 2 - Perfis geo-elétricos obtidos através de sondagem por eletro-resistividade................. 093

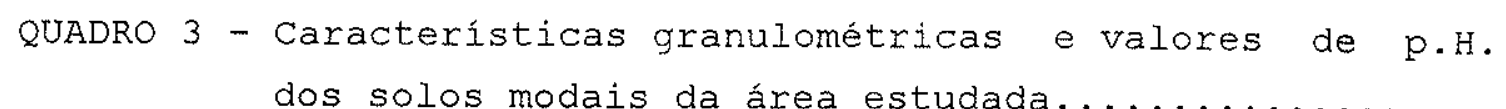

096

QUADRO 4 - Características físicas relacionadas a classificação H.R.B. (Highway Research Board) e indices de permeabilidade dos solos amostrados............ 097 
pág.

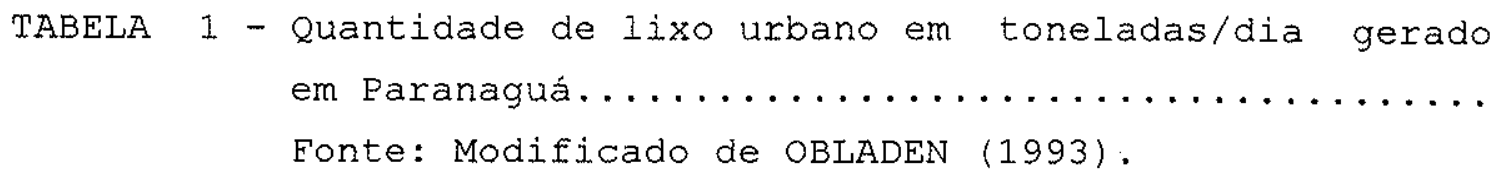

TABELA 2 - Dados utilizados para o traçado das isolinhas da superfície potenciométrica, aferidos em poços tipo

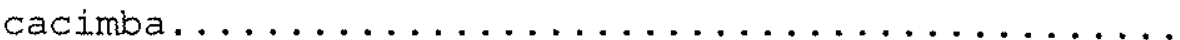

TABELA 3 - Dados utilizados para o traçado das isolinhas da superficie potenciométrica, aferidos em poços

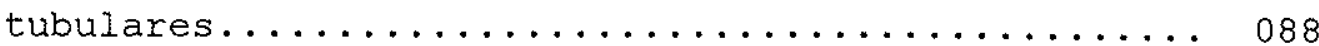

Fonte: Modificado de GIUSTI (1994).

TABELA 4 - Dados utilizados para o traçado das isolinhas da superficie potenciométrica, obtidos por sondagem

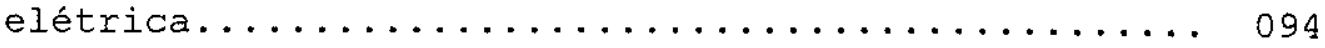


RESUMO

Este trabalho objetivou, através da caracterização do meio físico, determinar áreas favoráveis à implantação de aterros sanitários na porção sul do município de Paranguá - PR.

Para caracterizar o meio físico, foram executados levantamentos da geologia, geomorfologia, hidrogeologia e dos solos do local. Para os estudos hidrogeológicos foram elaborados um mapa potenciométrico e um mapa de vulnerabilidade dos aquíferos, e para auxiliar a determinação das superficies geomórficas, foi confeccionado um mapa de classes de declive.

Esses mapas, juntamente com o mapa geológico, das superficies geomórficas e dos solos, em escala 1:50.000, foram interpretados e discutidos, resultando em um mapa de caracterização das áreas para implantação de aterros sanitários.

Neste mapa estão representadas as áreas favoráveis, áreas favoráveis com restrições e áreas desfavoráveis à implantação de aterros sanitários.

As áreas favoráveis à implantação de aterros sanitários, são representadas por solos argilosos e impermeáveis, onde a profundidade do nível potenciométrico é superior a 2,0 metros de profundidade, o aqüífero é confinado ou semi-confinado e de baixa vulnerabilidade. As áreas favoráveis com restrições, são configuradas nos locais onde a profundidade do nível potenciométrico é inferior a 2,0 metros de profundidade, ocorrem agrupamentos de rios e ou poços, existem diáclases e ou falhas e dispõem-se assentamentos urbanos.

As áreas desfavoráveis à implantação de aterros sanitários, são representadas por solos siltosos, areia argilosa, pedregulho e areia argilosa e areia siltosa. A razão da desfavorabilidade deve-se aos teores de argila inferiores a 308 e índices de plasticidade inferiores a 15 unidades, em todos os solos, e permeabilidade elevada nos solos areia siltosa. Nesses locais os aqüiferos são semiconfinados e livres, com vulnerabilidade baixa e média no aqüifero semi-confinado e, alta no aqüífero livre.

- trabalho apresenta, ainda, uma análise da situação atual da disposição dos resíduos sólidos em Paranaguá, e comenta as principais normas, leis e resoluções utilizadas para a implantação de aterros sanitários. 
ABSTRACT

This work has the aim of defining the requirements for sanitary landfills in Southern Paranaguá, RR, based on the physical characterization of the area.

Potenciometric maps, aquifers vulnerability maps and geomorphic surfaces maps have been made and analyzed in combination with geological and pedological maps, all in 1:50 000 scale. The joined study of the data resulted in a sanitary Landfill Characterization Map, where suitable places, suitable places with restrictions and non-suitable places for sanitary dumpings are defined.

The so-called suitable areas are composed by impermeable clay soils, where the potenciometric depth level is up to $2,0 \mathrm{~m}$ and the aquifer is confined or semi-confined type, with low vulnerability. In the same way, the suitable areas with restrictions are related to places where the potenciometric level is located at a depth of $2,0 \mathrm{~m}$ at maximum, rivers and/or wells are grouped together, joints and/or faults are cutting the area and urban occupation is characterized. The non-suitable areas are defined by places where the soils present in its composition less than $30 \%$ of clay, plasticity index is below 15 unities and permeability is high. These soils are related to semi-confined and free aquifers with respectively, lowmedium vulnerability, and high vulnerability.

The work presents, in addition, an overview on the solid residues disposal situation in Paranaguá, $P R$ at presente, and discusses the main rules and regulations used in sanitary landfills implementation. 
A sociedade moderna, em função de atividades diversas, produz uma grande e variada quantidade de resíduos. A destinação final destes, pode ser $\circ$ meio aquoso e a superficie do solo, produzindo agressões ao meio ambiente.

Essas agressões se configuram na poluição de rios, mares, lagos, águas subterrâneas e solos.

No passado, prevaleceu a idéia errônea de que a disposição dos resíduos urbanos, distantes das comunidades não acarretariam problemas às mesmas. Porém, essa prática aliada à falta de planejamento e metodologia adequada propiciou o aparecimento de áreas de risco potencial ao meio ambiente.

Esse risco agravou-se com o crescimento desordenado dos centros urbanos, pois na maioria das vezes, os depósitos de lixo foram sub-estimados em relação a sua vida útil e quando englobados pelas cidades, tornaram-se áreas de agressão ambiental.

HEITZMANN JR. (1994), atenta para a forma inadequada na deposição dos resíduos sólidos, tendo em vista a falta de informação sobre o assunto no Brasil, e propõe formas de recuperação de três áreas com depósitos de resíduos sólidos, situados na Bacia do Rio Piracicaba no Estado de São Paulo.

Em pesquisas realizadas em locais com depósitos de resíduos em Nova Jersey, Illinois e Oregon nos Estados Unidos da América do Norte, LEMONT et al (1993) citado por WATTS et al. (1994), enfatizaram o risco de poluição nestes locais.

Na região Metropolitana de Recife, COSTA e SANTOS (1994) em um estudo hidrogeológico preliminar das águas subterrâneas no entorno da área do lixão de Muribeca, determinaram a contaminação da água subterrânea pelo chorume do lixão.

Somados a esses impactos ambientais, a localização dos depósitos de lixo em áreas urbanas provoca a proliferação de vetores de doenças, odores desagradáveis, impacto estético e problemas sociais relacionados com os catadores de lixo que comercializam residuos passíveis de reaproveitamento.

Em Paranaguá, principal centro urbano do litoral paranaense, esses fatos são evidenciados em vários locais de acúmulo de lixo, 
pois até recentemente uma parte do lixo urbano foi lancado em manguezais, que foram aterrados e urbanizados.

Essa prática causou graves conseqüências à população desses locais, bem como ao meio ambiente, destruindo os manguezais que são essenciais ao equilíbrio ecológico local.

Atualmente, o lixo urbano de Paranaguá é destinado para quatro depósitos situados em locais onde não foram efetuados estudos de caracterização do meio físico, configurando, portanto, áreas de risco ambiental.

Na tentativa de solucionar a problemática do lixo nos municípios litorâneos a superintendência dos Recursos Hídricos e Meio Ambiente, realizou em 1986 uma reunião com os prefeitos desses municípios, procurando expor um plano de implantação de centrais de triagem e compostagem de lixo, com capacidade para receber os resíduos gerados de forma integrada.

Tendo em vista as dificuldades financeiras dos municípios e a falta de vontade política na época, tal projeto foi abandonado.

Assim, denota-se a grande necessidade de estudos geológicos e hidrogeológicos de forma integrada com as informações geomorfológicas e pedológicas, para caracterizar o meio físico, de maneira a permitir a execução de normas municipais que regularizem a locação dos depósitos de resíduos sólidos no município de Paranaguá. 
2 .

OBJETIVOS

Estudos específicos dos aspectos geológicos, hidrogeológicos, pedológicos e geomorfológicos do município de Paranaguá, são poucos e dispersos. Com relação a informações sobre o meio físico para a locação de aterros sanitários, os estudos são praticamente inexistentes.

Portanto, o objetivo deste trabalho em caracterizar o meio físico para a implantação de aterros sanitários nesse município é importante, não só para o seu melhor conhecimento físico integrado, bem como, para estabelecer critérios que possam ser usados em outros municípios litorâneos com problemas semelhantes.

Como resultado final, elaborar-se-á mapa de classes de declividade, mapa geomorfológico, mapa geológico, mapa potenciométrico, mapa de vulnerabilidade de aqüíferos e mapa de distribuição dos tipos de solos em escala 1:50.000. Esses mapas analisados de forma integrada resultarão em uma carta em escala 1:50.000 que indique a distribuição de áreas adequadas para instalação de aterros sanitários. 
3.

REVISÃO BIBLIOGRÁFICA

Tendo em vista o objetivo do trabalho, a revisão bibliográfica foi dividida em dois ítens.

No primeiro item, foram relacionadas as principais normas nacionais usualmente utilizadas na locação de aterros sanitários e a legislação federal e estadual pertinente ao assunto.

No segundo item são apresentados os trabalhos referentes a caracterização do meio físico, relacionados com a locação de áreas para implantação de aterros sanitários e sobre aterros já implantados.

3.1. Normas e Legislação

A Companhia de Tecnologia e Saneamento Ambiental - CETESB, em CETESB (1983) e CETESB (1985), propõe normas com as caracteristicas dos solos, a profundidade do lençol freático, distanciamento dos rios, as declividades e as características dos acessos recomendáveis para os locais de implantação de aterros sanitários de residuos sólidos urbanos e industriais.

Com relação aos critérios para apresentação de projetos para aterros sanitários, a Associação Brasileira de Normas Técnicas A.B.N.T., através das Normas Brasileiras Registradas - N.B.R., estabelece as condições mínimas exigíveis para apresentação de projetos de aterros sanitários de residuos industriais perigosos na N.B.R.-8418 (A.B.N.T., 1984) e para aterros sanitários de resíduos sólidos urbanos na N.B.R.-8419 (A.B.N.T., 1984). Na N.B.R.-8849 (A.B.N.T., 1985) são fixadas as condições para a apresentação de projetos de aterros controlados de resíduos sólidos urbanos e na N.B.R.-10157 (A.B.N.T., 1987) são estabelecidas as condições para projeto e operação de aterros de resíduos perigosos.

A legislação federal na Portaria no 53 de 01/03/79, fixa normas para os projetos específicos de tratamento e disposição final de resíduos sólidos, bem como a fiscalização para a implantação dos mesmos.

- Conselho Nacional do Meio Ambiente - CONAMA, na sua Resolução 01 (CONAMA, 1986) resolve em seu Artigo 20 que o licenciamento de atividade modificadoras do meio ambiente, como 
aterros sanitários, processamento e destino final de residuos tóxicos ou perigosos, dependerá de elaboração de estudo de impacto ambiental e respectivo relatório de impacto ambiental, a serem submetidos à apreciação do órgão estadual competente e da SEMA em caráter supletivo.

- Artigo $2^{0}$ da Resolução 06 (CONAMA, 1991) estabelece que os órgãos estaduais de meio ambiente fixarão normas para tratamento especial como condição para licenciar a coleta, o transporte, o acondicionamento e a disposição final dos resíduos sólidos que não sejam incinerados, provenientes dos estabelecimentos de saúde, portos e aeroportos.

A Resolução 08 (CONAMA, 1991) em seu Artigo 19 proibe a entrada no pais de materiais residuais destinados à disposição final e incineração no Brasil.

Na Resolução 05 (CONAMA, 1993), fixa em seu Artigo 2ㅇ a aplicação desta Resolução para os resíduos sólidos gerados nos portos, aeroportos, terminais ferroviários e rodoviários e estabelecimentos prestadores de serviços de saúde, estabelecendo também, no Artigo $4^{\circ}$ que cabe aos estabelecimentos referidos no Artigo 2으 - gerenciamento de seus resíduos, desde a geração até a disposição final, de forma a atender aos requisitos ambientais e de saúde pública. Nessa Resolução, em seu Anexo 1, os resíduos sólidos gerados nos estabelecimentos a que se refere o Artigo 2\%, são classificados em:

Grupo A: residuos que apresentam risco potencial à saúde pública e ao meio ambiente devido à presença de agentes biológicos.

Grupo B: resíduos que apresentam risco potencial à saúde pública e ao meio ambiente devido às suas caracteristicas químicas.

Grupo C: rejeitos radioativos.

Grupo D: resíduos comuns que não se enquadram nos grupos descritos anteriormente.

A legislação estadual paranaense propõe imposição de normas técnicas para as unidades de tratamento e descarga de esgoto sanitário, águas servidas e deposição de lixo e detritos, 
principalmente no que respeita aos conjuntos hoteleiros e residenciais devendo ser de exclusiva responsabilidade do empresário a construção desses equipamentos. Esta imposição está expressa no Artigo 2ㄴ letra f da Lei n 7389 de $12 / 11 / 80$ que considera locais de interesse turístico e engloba o município de Paranaguá.

ROHDE (1989), estabelece um método para a seleção de áreas destinadas à estruturação de aterros sanitários, a partir da caracterização do meio físico, dos parâmetros do sistema urbano e da produção de residuos, bem como, faz uma análise crítica da N.B.R.8419 (A.B.N.T., 1984) e N.B.R. -8849 (A.B.N.T., 1985).

No Estado de São Paulo, a Secretaria do Meio Ambiente - SMA (1991) publicou um Manual de critérios de exigências de estudos de impacto ambiental e o roteiro para elaboração de relatórios de impacto do meio ambiente, aplicados para aterros de residuos sólidos domiciliares e industriais.

HAHNER (1994), propõe um estudo que prevê a participação de todos os órgãos, empresas, associações - públicas e privadas - que direta ou indiretamente tem responsabilidades ou interfaces com os problemas de geração, coleta, transporte, tratamento e disposição final de residuos sólidos, visando a implementação de um plano diretor de resíduos sólidos da Região Metropolitana de são Paulo. Entre as principais dificuldades a serem equacionados, são citadas a identificação de áreas para a implantação dos sistemas de destinação final de lixo, tendo em vista a elevada urbanização e as restrições ambientais.

\subsection{Caracterização do Meio Físico}

ELLERT et al (1986), indicam a aplicabilidade de métodos geofísicos, tais como a eletrorresistividade, principalmente em seu procedimento de caminhamento elétrico e o eletro-magnético indutivo, como procedimentos indiretos, para fins de locação da extensão e de certa forma, da intensidade de poluição do sub-solo, por parte de agentes advindos de aterros sanitários e deposição de vinhoto.

PARISOT et al (1985), executaram um monitoramento das águas subterrâneas a jusante do aterro sanitário de Taubaté com a instalaçào de 36 poços de observação. No ambiente hidrológico 
estudado, a condutividade, o sódio, o cloreto e o nitrogênio amoniacal constituíram indicadores da poluição pelo lixo.

GRENHOUSE et al (1987) reportam o progresso da evolução dos equipamentos geofisicos para medir condutividade dos terrenos e, exemplificam com os levantamentos geofísicos efetuados no aterro municipal de Taubaté e aterro municipal de Novo Mundo, concluindo que essa evolução é extremamente benéfica para a exploração da água subterrânea.

MENDES (1987), utilizando-se de método eletromagnético indutivo e de eletrorresistividade, estabeleceu critérios para auxiliar na recuperação de áreas poluídas e ou contaminadas, alertando os responsáveis pelo controle das condições de meioambiente para o problema da poluição das águas subterrâneas.

Valendo-se da aplicação do método eletromagnético, ELLERT e ROSA FILHO (1988), detectaram fluxo de poluentes partindo do lixão da Lamenha Pequena em Curitiba e a existência de falhamento no substrato rochoso.

ELLERT et al (1990), utilizaram vários métodos geofísicos de prospecção na região do lixão de São Carlos - SP, com a finalidade de se determinar a presença e extensão de qualquer nuvem poluente, advinda da deposição de lixo urbano em uma antiga boçoroca. Concluiram esses autores que os métodos geofísicos se revelaram de grande aplicabilidade no caso específico de são carlos, para atingir a finalidade do trabalho.

GONÇALVES et al (1992), fizeram a determinação da direção de fluxo de água do lençol freático que percola o aterro sanitário de São Carlos, através da construção de piezômetros e medidas diretas dos níveis d'água em cada um deles, com a obtenção da superfície potenciométrica.

Apresentando considerações sobre as etapas de análise de viabilidade, projeto, implantação e operação de aterros sanitários, com especial ênfase aos aspectos relacionados às águas subterrâneas, SCHALCH et al. (1992), fizeram um relato dos estudos para implantação de aterro sanitário na cidade de Bauru - SP, onde foram consideradas medidas complementares às recomendações e sugestões dos órgãos responsáveis pela análise do EIA/RIMA - Estudo de impacto Ambiental/Relatóxio de Impacto do Meio Ambiente. 
LEMONT et al (1993), citado por WATTS et al. (1994), delinearam o modo de tratamento do risco ecológico na investigação em depósitos de residuos perigosos. Enfatizaram elementos indicadores de contaminação, taxas elevadas de elementos químicos e as características de risco. Esses modos de tratamento foram aplicados em depósitos de resíduos perigosos situados em Nova Jersey, Illinois e Oregon.

SCUDINO (1992), com o intuito de avaliar a possibilidade de poluição dos aqüíferos em área de embasamento cristalino com espesso manto de intemperismo, tendo em vista a implantação de um aterro sanitário para disposição de resíduos sólidos, estudou o fluxo e a qualidade das águas de infiltração. Esses estudos objetivaram a elaboração de um plano de monitoramento da qualidade dessas águas, no eventual risco de poluição.

COSTA e SANTOS (1994), realizaram um estudo hidrogeológico preliminar a fim de detectar possiveis niveis de poluição das águas subterrâneas no entorno da área do lixão de Muribeca, situado na Região Metropolitana de Recife, revelando uma contaminação restrita na área aluvionar porosa situada nas proximidades do lixão.

Com a finalidade em elaborar mapas orientativos para delimitação de áreas favoráveis e desfavoráveis a instalação de aterros sanitários, MENTE et al (1994), cotejaram o quadro geológico e hidrogeológico das áreas estudadas e suas respectivas interações. Para tal, definiram a vulnerabilidade natural dos aquíferos, utilizando os dados disponíveis e os limites de resolução da escala, e levaram em consideração a importância do aqưífero para o abastecimento de água na Região Metropolitana de Recife. FUZZARO (1994), caracteriza os tipos de aterros sanitários e lembra algumas regras básicas para a localização dos mesmos.

VAN IMPE (1995), conclue que a cobertura ou a impermeabilização de aterros com solo pode provocar contaminação do meio ambiente quando os solos são instáveis, sendo que, 0 uso de material sintético para tal fim, permite melhor dimensionamento da interação entre os resíduos depositados e esse tipo de impermeabilização. 
4. MATERIAIS E MÉTODOS

4.1. Materiais

4.1.1. Localização Limites e Acessos

- local em estudo abrange a porção sul do município de Paranaquá, entre os paralelos $25^{\circ} 30^{\prime}$ e $25^{\circ} 45^{\prime}$ de latitude sul e os meridianos $48^{\circ} 15^{\prime}$ e $48^{\circ} 44^{\prime}$ de longitude oeste, configurando uma area de $637,00 \mathrm{~km}^{2}$ (Figura 1).

O municipio de Paranaguá, situado no litoral paranaense, compreende uma área terrestre de $665,41 \mathrm{~km}^{2}$ e limita-se ao norte com os municípios de Antonina e Guaraqueçaba, ao sul com os municípios de Matinhos e Guaratuba, a oeste com o município de Morretes e a leste com o Oceano Atlântico.

A principal estrada de acesso com a sede municipal é a BR277 (Curitiba-Paranaguá), sendo ainda o município cortado pela PR-508 (Alexandra-Matinhos), PR-407 (BR-277 - Praia de Leste) e a PR-412 (Pontal do sul - Caiobá) (Figura 2). Existem ainda inúmeras trilhas e estradas vicinais, bem como a Eerrovia que liga o município a Curitiba e outras cidades do litoral.

A comunicação com a ilha da cotinga e Ilha do Mel, que fazem parte do município de paranaguá é feita através de barcos, sendo que em épocas de veraneio tornam-se linhas maritimas regulares.

A ligação com a ilha de valadares é feita através de passarela, que localiza-se na região do Mercado Municipal de Paranaguá. 


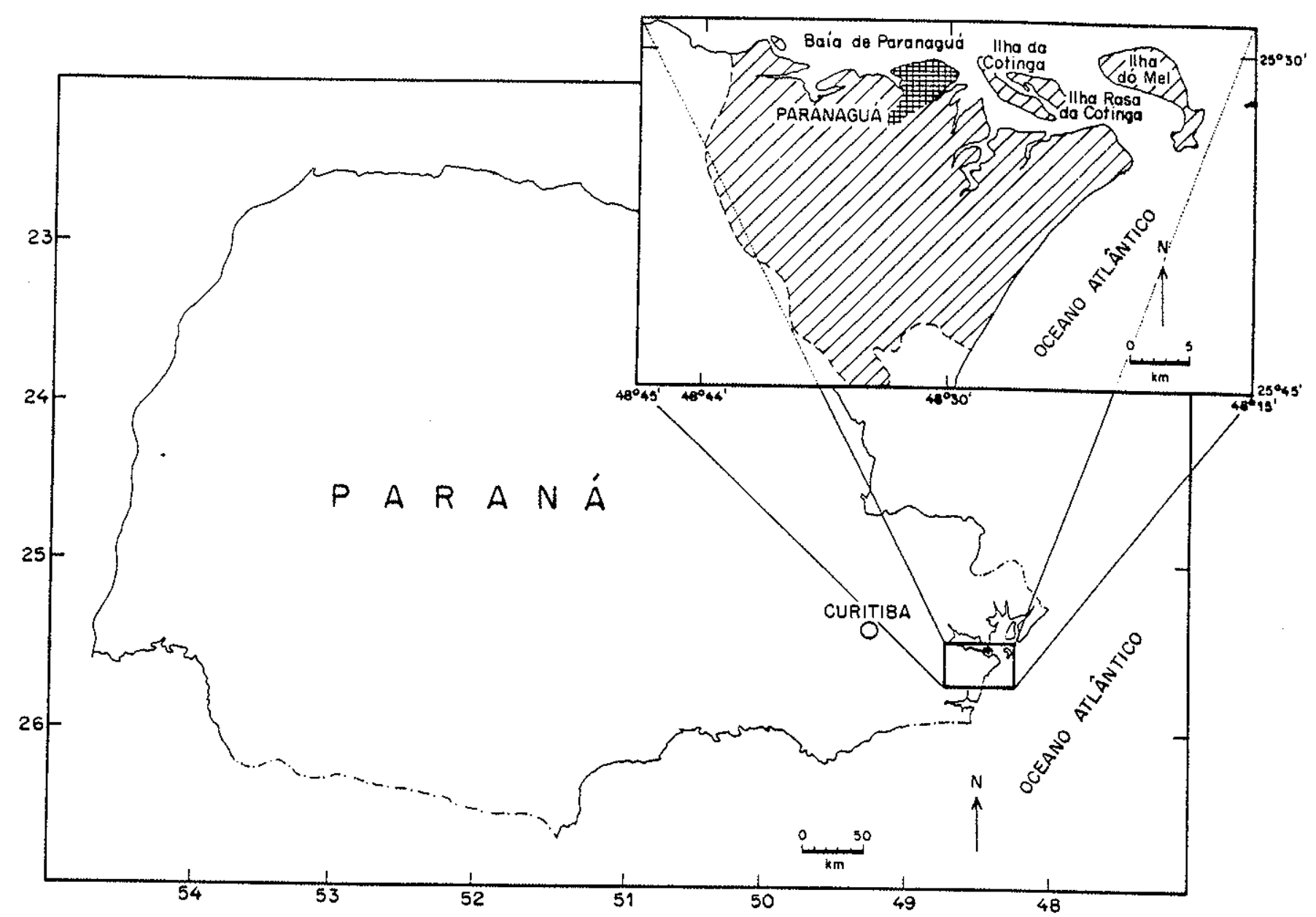

EIGURA 1 - Localização da Área.

Eonte: Modificado de NIMER (1977). 


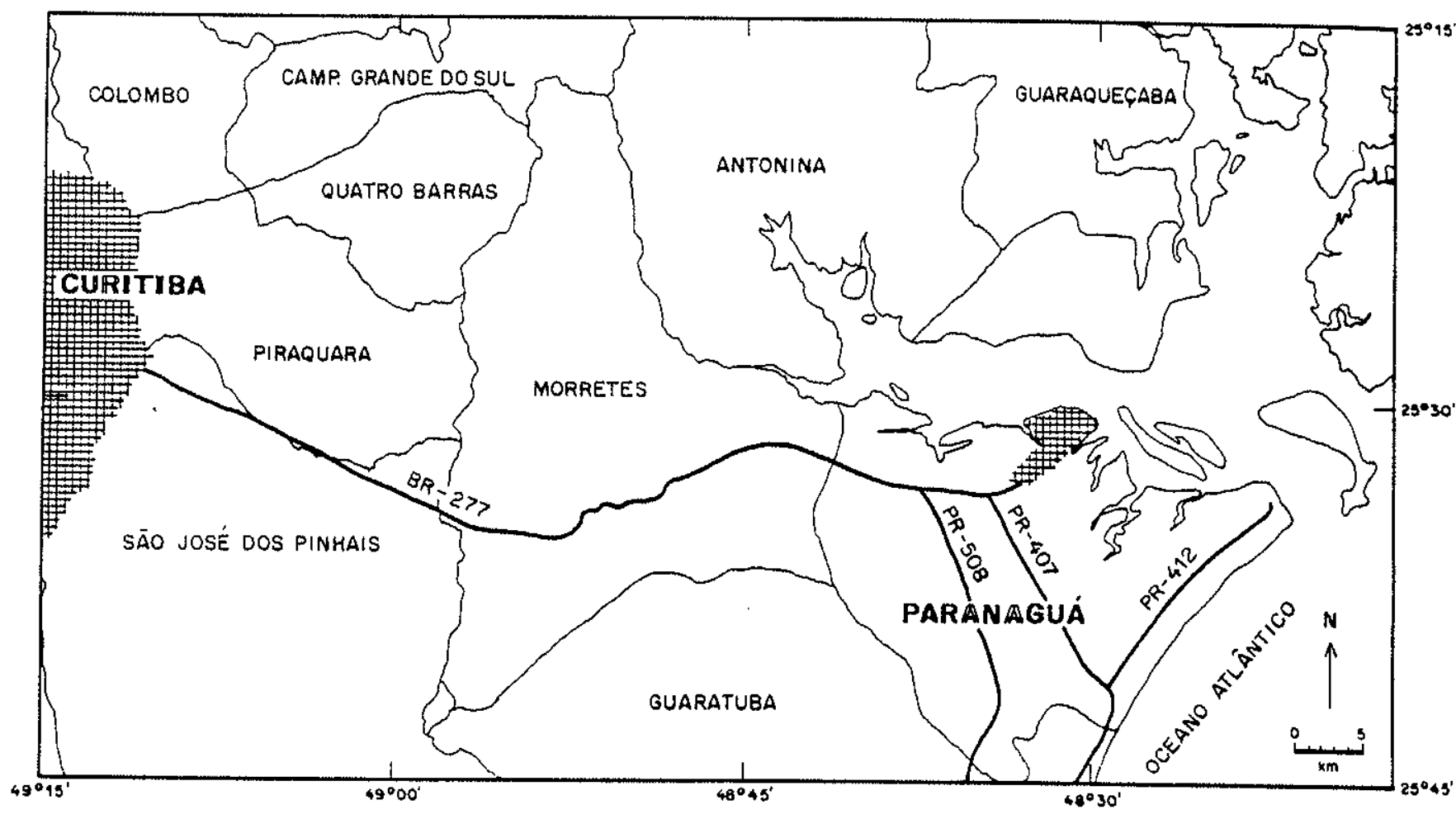

FIGURA 2 - Mapa de Acesso a Área.

Fonte: Modificado do mapa do Estado do Paraná. ITCE-PR, (1990). Escala 1:500.000. 


\subsubsection{Geologia}

- contexto geológico da área é composto por migmatitos gnaisses e granitos do pré-Cambriano, diques de diabásio do Mesozóico e conglomerados, arenitos, argilitos e sedimentos arenosos e arenoargilosos do Pleistoceno e, sedimentos arenosos, areno-silticoargilosos, depósitos de tálus, coluviões e aluviões do Holoceno. (RIVEREAU et al, 1969).

No Mapa Geológico do Estado do Paraná (MINERopAr, 1989), o município de Paranaguá se localiza na região costeira do escudo, na qual são distinguidas as seguintes unidades litoestratigráficas:

a) Complexo gnáissico migmatítico costeiro do Proterozóico inferior, composto principalmente por granitos gnaissicos e de anatexia e migmatitos;

b) Intrusivas básicas do mesozóico, principalmente diabásios e dioritos, que ocorrem na forma de diques;

c) Eormação Alexandra formada por sedimentos arenoargilosos estratificados, na base, e conglomerados, arcósios, argilitos e arenitos no topo, de idade pleistocênica;

d) Sedimentos recentes constituidos por depósitos arenosíltico-argilosos de origem marinha e continental, os depósitos de mangues, os colúvios e elúvios.

Os lineamentos estruturais, segundo FuCK et al (1969), na região de Paranaguá-Guaratuba atingem orientações $\mathrm{N} 20^{\circ} \mathrm{E}, \mathrm{N} 30^{\circ} \mathrm{E}$ até $\mathrm{N}-$ S. Esses alinhamentos adquirem orientações $N 60^{\circ} \mathrm{E}$ ao norte da Baia de Paranaguá e $\mathrm{N} 40^{\circ} \mathrm{E}$ próximos a costa.

Regionalmente, destaca-se $\circ$ arco de Ponta Grossa cujo eixo orientado para NW mergulha para o interior da Bacia do Paraná. Durante o magmatismo cretáceo, sua grande elevação causou intenso fraturamento distensivo e falhamentos, vias de acesso do magma à superficie, atestada pelo enxame de diques de diabásio e algumas intrusões alcalinas (ALMEIDA, 1981).

ASMUS e FERRARI (1978), discutindo o tectonismo cenozóico, demonstram a expressão desse evento em falhas com rejeitos normais e verticais, ao longo de linhas de fraqueza pré-cambrianas, que 
resultaram em escarpas de linha de falha, semeihantes às da serra do Mar.

Recentemente, RICCOMINI et al (1989) se referem a falhamentos de idades pleistocênicas-holocênicas que constituem os sistemas de falhas da serra do Mar.

\subsubsection{Hidrogeologia}

Com relação a hidrogeologia, são poucas as informações existentes sobre o município de Paranaguá.

ELLERT e GIUSTI (1984), executaram sondagem elétrica vertical na região do Porto de Paranaguá e determinaram com base em valores de resistividade, uma profundidade máxima de 2,0 metros para - lençol freático. Verificaram também, uma camada de areia saturada de água doce com espessura de 18,0 metros e que a partir de 20,0 metros de profundidade ocorria a presença de água salgada.

Em sondagem elétrica executada em uma região situada a sW do Porto de Paranaguá, GIUSTI (1989) concluiu que a profundidade do nível freático encontra-se entre 0,60 metros e 3,0 metros. Determinou uma camada arenosa saturada com água doce com espessura 6, 0 metros e a presença de água salgada a partir de 11,0 metros de profundidade. observou, também, que a profundidade média dos poços na região é de 25,0 metros e suas vazões mais freqüentes são de 3,0 a $5,0 \mathrm{~m}^{3} / \mathrm{h}$.

JOSÉ et alli (1994), através da execução de geofísica por eletroresistividade, em indústrias localizadas na Baia de Paranaguá, concluíram que a tendência fundamental de contaminação é na área interna das indústrias seguindo-se em direção a orla marítima, sendo que as captações nessa área de influência são vulneráveis a poluição.

4.1.1.4. Geomorfologia

A área em apreço localiza-se, segundo MAACK (1968), no litoral que foi dividido por esse autor em duas sub-regiones geográficas naturais, a sub-região montanhosa litorânea e a planicie litorânea.

A sub-região montanhosa litorânea é constituída por cadeias de montanhas que se elevam na planicie costeira e, representam ramificações da serra do Mar. Essas elevações em geral ultrapassam os 1000 metros. 
A sub-região planície litorânea, foi definida como formada principalmente por sedimentos marinhos do Quaternário resultantes do avanço da costa sobre o mar e de linhas rochosas abruptas de idades pré-cambrianas que constituem ilhas.

Essas sub-regiões foram denominadas de orla de serra e orla marinha por LOUREIRO EERNANDES (1947), correspondendo a sub-região montanhosa litorânea e planície litorânea, respectivamente.

BIGARELLA et al (1978), incluiu na serra do Mar a sub-região montanhosa de MAACK (1968), gerando duas concepçoes para a região geográfica serra do Mar que é o limite oeste da região litorânea.

No município de Paranaguá, a sub-região montanhosa litorânea está representada em uma pequena porção a sudoeste sendo que, a subregião planície litorânea abrange a área restante do município.

\subsubsection{Hidrografia}

A drenagem oriental do Estado do Paraná abrange uma região fisiográfica de dois tipos de compartimentos distintos, isto é, aqueles da serra do Mar e da baixada litorânea (BIGARELLA et al 1978).

A bacia hidrográfica de Paranaguá, que abrange extensa área da baixada litorânea, é composta na região estudada pelo rio das Pombas ao sul, rios Embocuí e Emboguaçu ao Norte e pelo rio Jacareí no extremo Oeste.

Na parte central, ocorrem o rio Guaraguaçu, rio dos Correias, rio Itiberê, rio dos Almeidas e rio Cachoeira.

$\mathrm{Na}$ porção sudeste, os principais rios correm paralelos ou sub-paralelos a costa e, destacam-se o rio Balneário, rio perequê e rio Penedo.

4.1.1.6. Solos

Os solos do litoral paranaense, segundo a Empresa Brasileira de Pesquisa Agropecuária - EMBRAPA, em EMBRAPA (1977) abrangem Podzólicos Vermelho-Amarelos, Latosolos Vermelho-Amarelos, Cambisolos, Solos Litólicos, solos Indiscriminados de mangues e solos Hidromórficos Gleyzados Indiscriminados.

LARACH (1984), classifica os solos da baixada litoranea como solos podzólicos, aluvião e áreas como solos de mangue. 
Segundo a classificação adotada pelo Serviço Nacional Levantamento e Conservação de Solos da EMBRAPA, citado por BIGARELLA et al (1978) os solos de Paranaguá são classificados em: Latosolo Vermelho-Amarelo; Podzólico Vermelho-Amarelo; Associação de Podzólico Vermelho-Amarelo mais solos Hidromórficos Gleyzados Indiscriminados; Podzol; Solos Indiscriminados de mangue.

4.1.1.7. Clima

- litoral paranaense está sob influencia direta do anticiclone móvel polar, do anticiclone do Atlântico e da depressão do Chaco. (Figura 3)

- anticiclone móvel polar produz as massas polares Atlântica - Pacifica, devido a divisão em dois ramos da massa polar, quando esta encontra a cordilheira dos Andes.

Mesmo sendo a massa polar Atlântica a que mais participa na circulação regional, a massa polar Pacifica, encontrando oposição na massa tropical Pacifica, desvia-se, estabelecendo um fluxo para sw e $\mathrm{NE}$ que, conseguindo transpor a cordilheira, vai reforçar a massa polar Altântica (BERNARDES et al (1978).

- anticiclone Atlântico constitue a massa tropical maritima atlântica que durante todo ano produz ventos que progridem em direção ao interior do Estado do Paraná.

A depressão do chaco, zona depressionária para onde convergem os ventos da massa polar e massa tropical atlântica, situase nos limites Brasil-Bolívia, gerando instabilidade e chuvas no território paranaense.

Segundo NIMER (1977), além desses centros participam no quadro da circulação atmosférica da região sul, as altas tropicais que se encontram representadas pela letra A na figura 3.

De acordo com a classificação de Koeppen, BIGARELLA et al (1978) enquadra o clima de Paranaguá como do tipo:

- Cfa: subtropical úmido mesotérmico, com verão quente. o mês mais frio apresenta temperatura média Inferior a $18^{\circ}$, porém superior a $-3^{\circ}$, e o mais quente temperatura média superior a $22^{\circ}$. Está sujeito a 


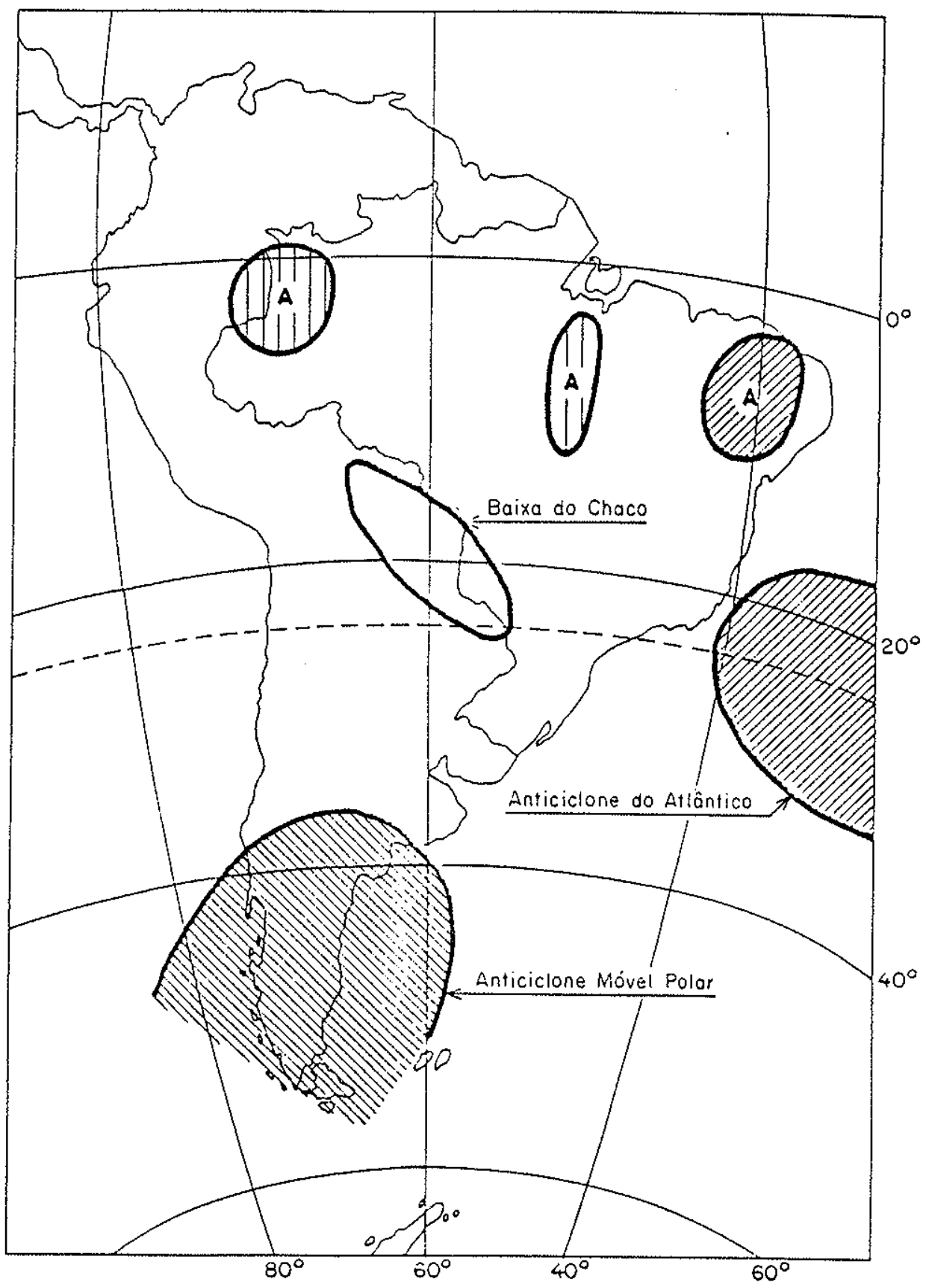

EIGURA 3 - Centros de ação sobre a área em estudo. Eonte: Modificado de NIMER (1977) 
geadas pouco freqüentes, a precipitações regulares todos os meses e não apresenta seca definida.

Analisando dados pluviométricos da serra do Mar, em particular do posto do Véu da Noiva, BIGARELLA et al (1978), afirmou que havia maior ocorrência de precipitações na serra do Mar que na Planície Litorânea.

Contudo, segundo O INSTITUTO PARANAENSE DE DESENVOLVIMENTO SOCIAL - IPARDES, em IPARDES (1990), o posto do Véu da Noiva apresenta uma anomalia pluviométrica que é explicada pela localização dessa estação. Este posto situa-se em um vaje que contitui um corredor de massas de ar provindas do Oceano Atlântico. Essas massas de ar ocasionam turbulência e condensação, geralmente, seguidas de precipitação.

Assim, tendo em vista os dados de 26 postos pluviométricos distribuidos em diferentes altitudes, o IPARDES (1990), concluiu que as precipitações são maiores na planície litorânea.

Em Paranaguá, os índices pluviométricos, segundo o IPARDES (1990) atingem $2378 \mathrm{~mm} /$ ano com 185 dias de chuva por ano. Esses dados foram registrados pelas estações de Paranaguá e Guaraguaçu.

Com relação ao tipo das chuvas, no litoral paranaense, são dos tipos ciclônico, orográfico e de convecção (IPARDES, 1990). Em Paranaguá, predomina o tipo de convecção, sendo que no verão as precipitações são maiores, podendo atingir em 24 horas máximas de aproximadamente $400 \mathrm{~mm}$.

Essas características possibilitam excedentes hídricos em Paranaguá, não havendo deficiência. Através da classificação de Thorntwaite, segundo o Instituto Agronômico do Paraná - IAPAR, em IAPAR (1978), no litoral paranaense os índices hídricos são do tipo úmido, variando entre $60-100 \mathrm{~mm}$ por mês.

Apesar dos excedentes hídricos serem superiores a $500 \mathrm{~mm}$ ano, podem ocorrer períodos de deficiência hídrica.

Segundo o IPARDES (1990), estudos sobre balanços hídricos de periodos consecutivos de dez dias, demonstraram ocorrência de déficit hídrico em periodos de até dois meses de duração.

Os ventos em Paranaguá, segundo MAACK (1968), predominam do setor sul $(22,88)$, ficando em segundo plano os ventos continentais do 
Sudoeste, Oeste e Noroeste $(33,2 z)$ e por último os ventos do setor Leste e Sudeste $(20,338)$ (Figura 4$)$.

Os dados fornecidos pela estação meteorológica de pontal do Sul, referentes ao período de setembro de 1982 a dezembro de 1986 (PORTOBRÁS, 1988) revelam uma predominância dos ventos com direção Leste $(8,58)$ e Sul $(9,38)$, com velocidades médias anuais de $5 \mathrm{~km} / \mathrm{h}$.

\subsubsection{Vegetação}

Conforme MAACK (1968), as matas do litoral apresentam intercalações de faixas pantanosas, lagoas abertas e gramineas, sendo que, aumentando a altitude ocorrem a floresta pluvial Tropical e subtropical do litoral da Serra do Mar. Na orla maritima, esse autor, coloca as comunidades vegetais que ocorrem sobre sedimentos arenosos, em habitat salino e ambientes de escassa pluviosidade.

A maior parte da planície litorânea e da serra do Mar é abrangida pela floresta ombrófila densa (IPARDES, 1990). Essa mata, pode ser dividida segundo critérios de altitude, em: floresta ombrófila densa das planicies quaternárias, entre 40-50 metros; floresta ombrófila densa sub-montana, entre 50-700 metros; a floresta ombrófila densa montana de 700-1400 metros; e acima de 1400 metros a floresta ombrófila densa alto montana.

A região de paranaguá de acordo com a classificação do projeto RADAM-BRASIL, segundo O IPARDES (1990), abrange parte da floresta ombrófila densa e as áreas de formações pioneiras.

As áreas de formação pioneiras, constituem os ambientes revestidos por vegetação de primeira ocupação, que se instala sobre áreas pedologicamente instáveis, devido às constantes deposições sedimentares ao longo do litoral, nas margens dos cursos d'água e ao redor de pantanos, lagunas e lagoas (IPARDES, 1990). 


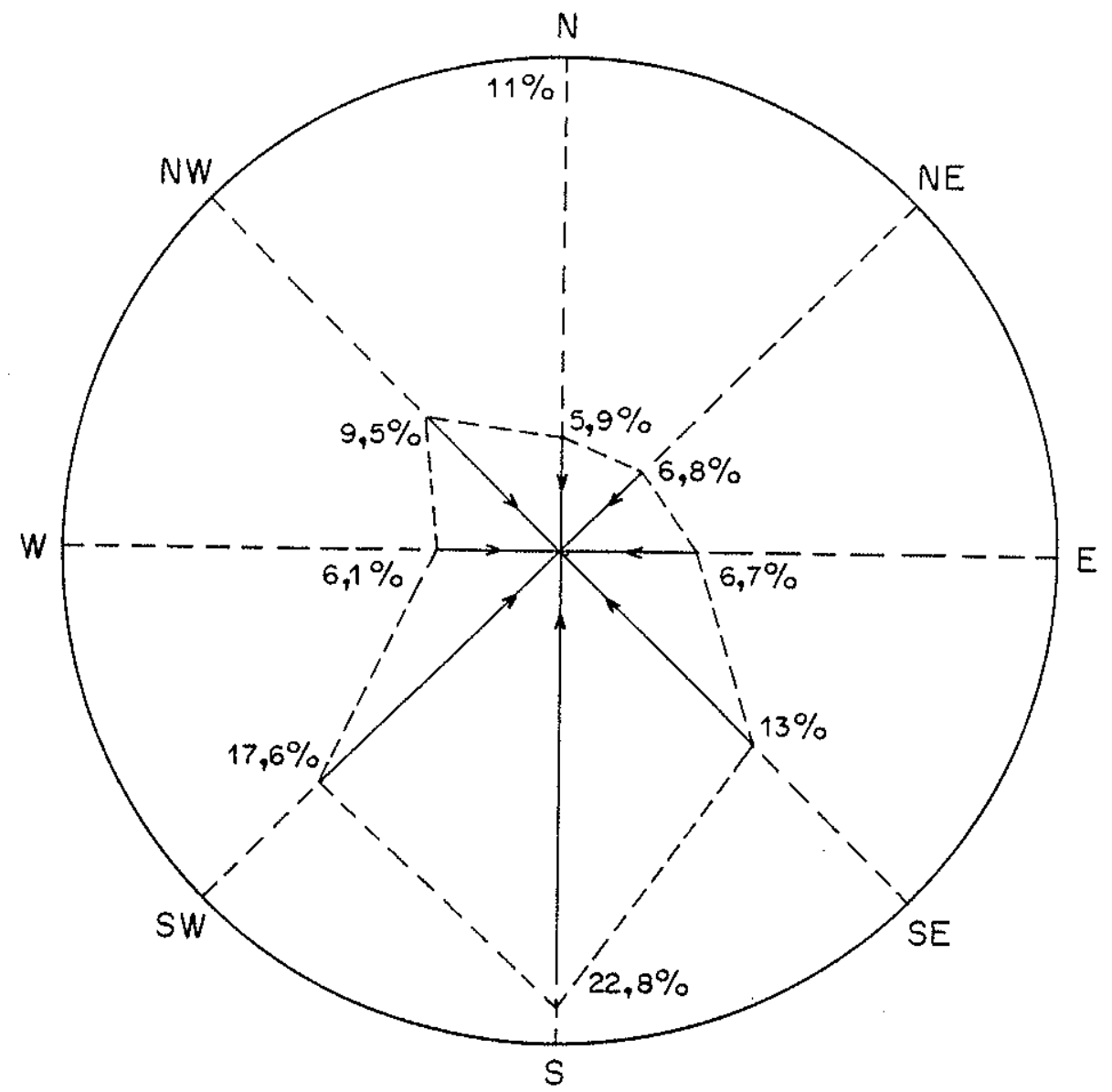

EIGURA 4 - Direção e frequência dos ventos em Paranaguá. Fonte: MAACK (1968). 
4.2. Métodos

4.2.1. Métodos de Campo

Esta fase do trabalho dividiu-se em cinco etapas: mapeamento geológico, mapeamento geomorfológico, levantamento do nivel potenciométrico, levantamentos geofísicos e descrição de perfis e coleta de amostras de solo.

\subsubsection{Mapeamento Geológico}

Tendo como base a folha geológica da Ilha do Mel e a folha geológica de Paranaquá, escala 1:70.000 (RIVEREAU et al 1968, 1969), que abrangem a área estudada, bem como, 0 mapa dos sedimentos cenozóicos do litoral do Estado do Paraná, folha Paranaguá, escala 1:50.000 (Angulo, 1992), e ainda uma fotointerpretação em escala 1:70.000, procedeu-se aos trabalhos de campo.

No campo foram verificadas as delimitações das litologias, sendo efetuadas algumas modificações em relação aos mapas existentes e, determinadas as diáclases e falhas levantadas com a fotointerpretação.

Após a delimitação das litologias, reconhecidas no campo e a locação das diáclases e falhas levantadas, foi elaborado um novo mapa geológico em escala 1:50.000, que posteriormente foi digitalizado usando-se o software Sistema Geográfico de Informações - S.G.I., do Sistema de Tratamento de Imagens - SITIM do Instituto Nacional de Pésquisa Espacial - I.N.P.E.

\subsubsection{Mapeamento Geomorfológico}

Conhecida a geologia do local, observaram-se as características fisiográficas da Região Montanhosa Litorânea e da Planície Litorânea, tendo em vista a divisão da área em unidades geomorfológicas.

Para essa divisão tomou-se como base os trabalhos de BIGARELLA et al (1965) e ROCHA et al (1992).

Configuradas as unidades geomorfológicas da área, foi elaborado em mapa geomorfológico em escala 1:50.000 que foi digitalizado usando-se o software S.G.I. - Sistema Geográfico de Informações do Sistema de Tratamento de Imagens do I.N.P.E. 
4.2.1.3. Levantamento do Nível Potenciométrico

Após o cadastramento de 41 poços tubulares e 13 poços tipo cacimba, foram medidas as profundidades de água nos poços tipo cacimba e anotada a profundidade do nível estático da água, a partir dos documentos de perfuração, dos poços tubulares.

Para medir a profundidade de água dos poços tipo cacimba, a partir da boca do poço, foi usada uma trena ou em alguns casos, nos poços mais profundos, uma corda com um peso em sua extremidade. Com a trena, visualizando-se o interior do poço com uma lanterna, a medida foi feita diretamente. Quando utilizada a corda, esta foi arremessada no interior do poço, de forma a ficar esticada até encontrar o nível de água, sendo posteriormente retirada e medido o comprimento aferido até o nível de água do poço.

\subsubsection{Levantamento Geofísico}

Neste trabalho, utilizou-se a sondagem elétrica, como ferramenta para determinar a profundidade do lençol freático, tendo como finalidade $\circ$ levantamento do nível potenciométrico e de possiveis estruturas geológicas.

- uso de sondagens geofísicas para determinação da profundidade do lençol freático, tem sido empregada por vários autores Como ELLERT e ROSA FILHO (1988), PACHECO et al (1991), e recentemente por JOSÉ et al (1994) na região de Paranaguá.

Através da execução de 06 sondagens elétricas foi medida a resistividade elétrica de diferentes profundidades sob um mesmo ponto.

As medidas de campo foram executadas através de um arranjo de quatro eletrodos alinhados em superfície. Para cada posição dos eletrodos foram feitas medidas injetando no solo uma corrente elétrica de intensidade I, ligada a um miliamperimetro. A passagem desta corrente pelo solo provoca o aparecimento de uma diferença de potencial AV, entre os eletrodos que é lida em um milivoltimetro.

Assim a resistividade elétrica aparente dos materiais investigados foi calculada pela fórmula:

$$
\rho a=\Delta V / \operatorname{IxK}(o h m \times m)
$$

Onde $\mathrm{K}$ é o fator geométrico, que depende da posição dos eletrodos. 
Os dados obtidos foram lançados em um gráfico bilogaritimo, tendo no eixo das abciças o espaçamento entre os elementos e no eixo das ordenadas os valores correspodentes de resistividade elétrica.

Através do gráfico obtido se estabeleceu uma estrátigrafia geo-elétrica do solo e se detectou a profundidade do lençol freático. Essas profundidades permitiram determinar o nivel potenciométrico local.

\subsubsection{Descrição de Perfis e Coleta de Amostras de Solo}

A metodologia de coleta de amostras de solo foi baseada na proposição deste trabalho, ou seja, caracterizar os solos em função de sua granulometria, plasticidade e permeabilidade, permitindo sua classificação geotécnica.

Em cada ponto de amostragem, quando não situado em barrancos, foi aberto uma trincheira com $60 \mathrm{~cm} \times 100 \mathrm{~cm}$ de largura por $120 \mathrm{~cm}$ de profundidade. Isto possibilitou uma melhor observação das características dos solos.

$\mathrm{Na}$ coleta de material considerou-se também, a metodologia empregada por OLIVEIRA (1972), para diagnosticar as características superficiais e subsuperficiais dos solos.

Assim, a coleta de Material foi efetuada nas profundidades de $0-20 \mathrm{~cm}, 60-80 \mathrm{~cm}$ e $100-120 \mathrm{~cm}$ que foram denominadas, respectivamente, camadas $a, b$ e c.

Para as análises granulométricas e de limite de plásticidade, as amostras de solo foram coletadas com pá ao longo de uma das faces de cada trincheira.

As amostras indeformadas, para a análise de permeabilidade, foram coletadas em cilindros de aço com $12,0 \mathrm{~cm}$ de altura e 10,0 cm de diâmetro. Esses cilindros foram cravados verticalmente, cortandose a parede de cada trincheira até as profundidades das camadas amostradas. Após a penetração total do cilindro, cortou-se a amostra por baixo do molde com uma faca, sendo a mesma retirada do local.

Em seguida foram vedados os extremos do cilindro, com discos de madeira, fixados com fita adesiva. Após esse procedimento os cilindros foram colocados em sacos plásticos com a numeração do ponto amostrado. 
Para a descrição dos perfis dos solos em cada ponto de amostragem, foi verificado possíveis variações de granulometria, de resistência a seco e plasticidade, segundo o descrito para a identificação dos solos no campo por BERTRAM (1969).

4.2.2. Métodos de Laboratório

As análises granulométricas e de p.H. dos solos foram efetuadas no Laboratório de solos do setor de Ciências Agrárias da U.F.PR. e as análises para a classificação dos solos, de plasticidade e permeabilidade foram executadas no laboratório do departamento de Estradas e Rodagem do Paraná.

\subsubsection{Análise Granulométrica dos solos}

Essa análise foi efetuada utilizando-se 50 gramas de solo, após as amostras terem sido secas ao ar, destorroadas e passadas em peneira de $2 \mathrm{~mm}$ de malha. A dispersão das amostras foi executada com solução de hidróxido de sódio 0,1 Normal, segundo procedimento adotado por VETTORI (1969). A argila foi determinada pelo hidrômetro, a areia por peneiramento e pesagem e o silte por diferença.

Para a classificação dos solos, pelo sistema de Classificação Higway Research Board - H.R.B., executou-se o seguinte procedimento, ao determinar-se suas granulometrias:

a) Destorramento de $1,0 \mathrm{Kg}$ de amostra de solo, seca em estufa;

b) Peneiramento em peneira de malha $n \div 10$;

c) Retira-se 100 gramas do material passado na peneira $n^{0} 10$, que é dispersado em um agitador;

d) lavagem do material dispersado sob água corrente em uma peneira de malha $n^{\circ} 200$;

e) Secagem em estufa do material retirado na peneira nㅇ 200;

f) Peneiramento do material seco em peneiras n의 40, 100 e 200, sucessivamente.

4.2.2.2. Análise da Plasticidade dos Solos

ATTERBERG (1911), definiu o indice de plasticidade (I.P.) de

um solo como a diferença entre seus limites de liquidez (L.L.) e limites de plasticidade (I.P.). 
- Iimite de liquidez das amostras de solo foi determinado em laboratório por meio do aparelho de Casagrande com a fração do solo que passa na peneira $n^{\circ} 40$, segundo a N.B.R. -6459 (A.B.N.T., 1984).

- limite de plasticidade foi obtido, rolando-se pequenas quantidades de solo sobre uma placa de vidro até que o diâmetro do rolinho seja de $3 \mathrm{~mm}$ e começam a aparecer fissuras no solo. Determina-se o teor de umidade do rolinho neste instante, que representa o limite de plasticidade do solo, segundo o prescrito na N.B.R. -7180 (A.B.N.T., 1984).

\subsubsection{Análise da Permeabilidade dos Solos}

A permeabilidade pode ser definida como a propriedade dos solos que possibilita a passagem de fluidos através de seus espaços vazios.

Essa propriedade é expressa pela Lei de Darcy:

$$
\mathrm{V}=\mathrm{K} \cdot \mathrm{A} \cdot \mathrm{i}
$$

Onde $V$ é a velocidade de fluxo, $K$ é $O$ coeficiente de permeabilidade, $A$ é a área da secção transversal através da qual se produz o fluxo de água e $i$ o gradiente hidráulico.

- coeficiente da permeabilidade, segundo DAS (1983), é afetado por vários fatores, entre os quais:
a) Tamanho e forma das particulas.
b) Quantidades de poros.
c) Grau de saturação.
d) Composição das partículas do solo.
e) Estrutura do solo.
f) Viscosidade do permeante.
g) Densidade e concentração do permeante.

A determinação do coeficiente de permeabilidade pode ser efetuada em laboratório e no campo.

Neste trabalho optou-se pelo uso dos ensaios de laboratório, que serão efetuados em permeâmetros de carga constante e de carga variável. 
Para os solos de permeabilidade alta, como as areias, utiliza-se o permeâmetro de carga constante (Figura 5).

Para os solos de granulometria fina, que são atravessados por quantidades de água muito pequenas, o método de medição da permeabilidade foi executado com permeâmetro de carga variável (Figura 6).

- coeficiente de permeabilidade segundo CAPUTO (1973), nos ensaios realizados com permeâmetro de carga constante é dado pela expressão:

$$
K=\frac{V \cdot L}{\text { A. h. t }}
$$

Onde $V$, representa o volume de água percolado no intervalo de tempo t., em $\mathrm{cm}^{3}$, L. é a altura do corpo de prova em $\mathrm{cm}$., sendo $\mathrm{A}$. a área do corpo de prova em $\mathrm{cm}^{2}$, enquanto h. é a altura da carga de água constante do permeâmetro em $\mathrm{cm}$. , o t. é o tempo decorrido do início ao fim do ensaio medido em segundos.

A fórmula para o cálculo da permeabilidade, em ensaio de carga variável, segundo CAPUTO (1973), pode ser escrita como:

$$
\mathrm{K}=2,3 \frac{\mathrm{La}}{\mathrm{At}} \log 10 \frac{\mathrm{h} 1}{\mathrm{~h} 2}
$$

Onde L representa a altura do corpo de prova em $\mathrm{cm}$ e A. sua área em $\mathrm{cm}^{3}$, enquanto a. é a área interna do tubo de carga variável em $\mathrm{cm}^{2}$, ot. é o intervalo de tempo entre $h$. que é a carga hidráulica no instante $t=0$ e h1. que é a carga hidráulica depois do intervalo de tempo t., medido em segundos.

A temperatura da água usada no processo deve estar a $20^{\circ}$, a fim de uniformatizar os resultados dos ensaios e permitir a comparação entre os mesmos (CAPUTO, 1973). 


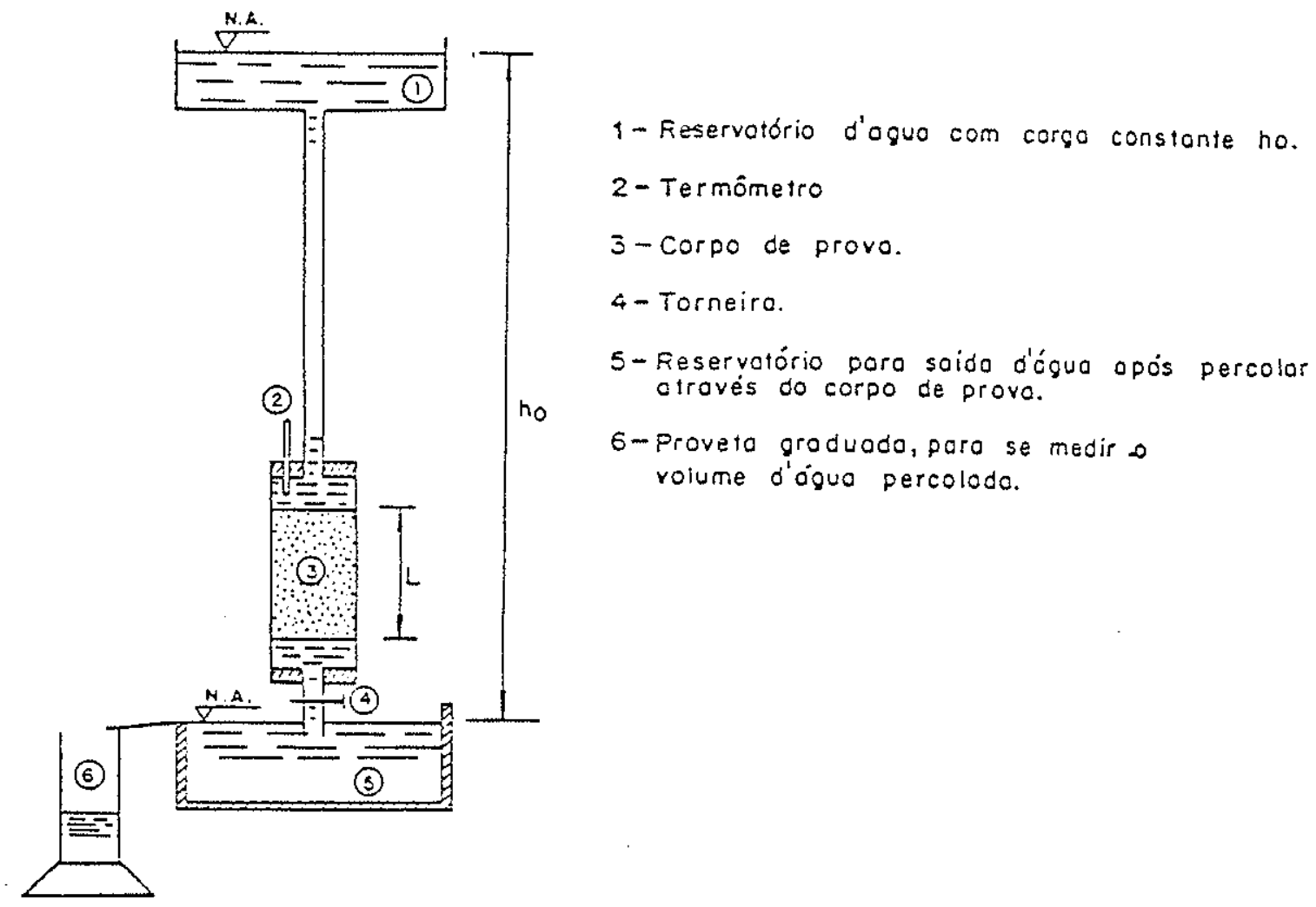

EIGURA 5 - Esquema de um permeametro de carga constante. Fonte: Modificado de caputo (1973). 


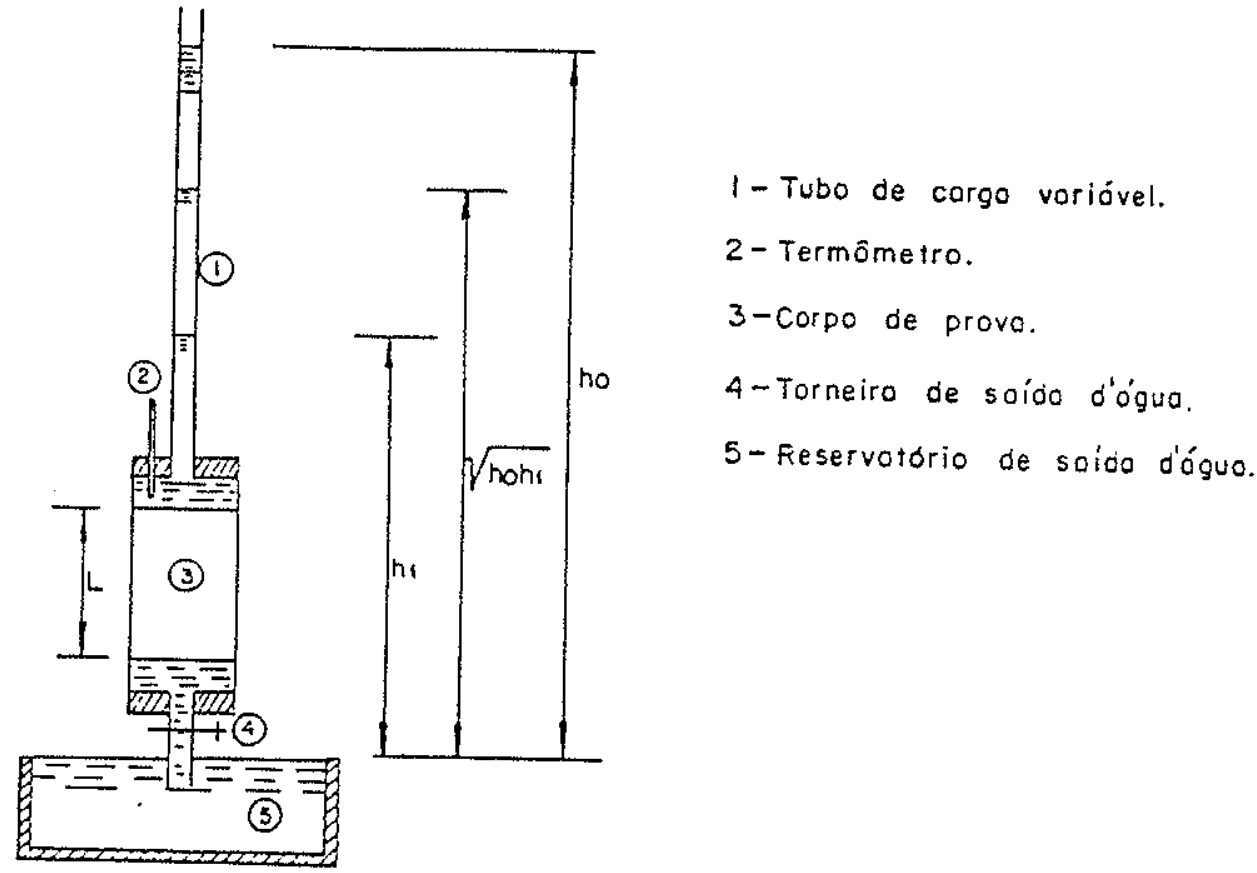

EIGURA 6 - Esquema de um permeâmetro de carga variável. Fonte: Modificado de CAPUTO (1973). 
Para se proceder aos ensaios, as amostras indeformadas contidas no corpo de prova, foram inicialmente rasuradas em suas bordas, colocadas no permeâmetro e saturadas com água em carga constante. Após a realização de várias repetições do ensaio, quando o peso da água a percolar a amostra tornou-se constante, determinou-se - coeficiente de permeabilidade.

4.2.2.4. Análise do p.H. dos Solos

- p.H. foi determinado potenciometricamente, na relação solo:água de $1: 2,5$, usando-se eletrodo de vidro, seguindo procedimento indicado por VETTORI (1969).

4.2.3. Classificação dos Solos

Tendo em vista a preocupação em relação a granulometria e plasticidade dos solos, na locação de áreas para instalação de aterros sanitários, a classificação dos solos foi elaborada de acordo com Classificação H.R.B. (HIGHWAY RESEARCH BOARD).

A Classificação H.R.B. foi proposta com o objetivo de ser usada na área de estradas, e os materiais são classificados em grupos e subgrupos em função da sua granulometria e plasticidade (CAPUTO, 1973).

Os grupos A-1, A-2 e A-3 englobam os solos granulares e os grupos A-4, A-5, A-6 e A-7 configuram os solos silto-argilosos. Esses grupos se subdividem em subgrupos como mostra o quadro 1.

Após feita a classificação dos solos, suas áreas de ocorrência foram delimitadas em um mapa escala 1:50.000, que posteriormente foi digitalizado no sistema Geográfico de Informações - S.G.I. do Sistema de Tratamento de Imagens do I.N.P.E. 


\begin{tabular}{|c|c|c|c|c|c|c|c|c|c|c|c|}
\hline \multirow{3}{*}{$\frac{\begin{array}{c}\text { Clossificocöo } \\
\text { Geral }\end{array}}{\text { Grupos }}$} & \multicolumn{7}{|c|}{ Solos Granulares $\left(P_{200}<35 \%\right)$} & \multicolumn{4}{|c|}{$\begin{array}{l}\text { Solos Silto-Argilosos } \\
\qquad\left(\mathrm{P}_{200}>35 \%\right)\end{array}$} \\
\hline & \multicolumn{2}{|c|}{$A \cdot 1$} & \multirow[t]{2}{*}{$A-3$} & \multicolumn{4}{|c|}{$A-2$} & \multirow[t]{2}{*}{$A \cdot 4$} & \multirow[t]{2}{*}{$A-5$} & \multirow[t]{2}{*}{ A-6 } & \multirow{2}{*}{$\frac{A-7}{A-7-5}$} \\
\hline & $A-1-0$ & $A-1-b$ & & $A-2-4$ & $A-2-5$ & $A-2-6$ & $A-2-7$ & & & & \\
\hline $\begin{array}{l}P_{10} \\
P_{40} \\
P_{2 \infty}\end{array}$ & $\begin{array}{l}<50 \\
<30 \\
<15 \\
\end{array}$ & $\begin{array}{l}- \\
<50 \\
<25\end{array}$ & $\begin{array}{l}> \\
>50 \\
<10 \\
\end{array}$ & $\frac{-}{<35}$ & $\overline{5}$ & $\overrightarrow{<35}$ & $\overline{<35}$ & $\overline{-}$ & - & ${ }^{-}$ & - \\
\hline LL & $<6$ & $\overline{<6}$ & $\overline{N P}$ & $\begin{array}{l}<40 \\
<10\end{array}$ & $\begin{array}{l}>40 \\
<10\end{array}$ & $\begin{array}{l}<40 \\
>10\end{array}$ & $\begin{array}{l}>40 \\
>10\end{array}$ & $\begin{array}{l}<40 \\
<10\end{array}$ & $\begin{array}{l}>40 \\
<10\end{array}$ & $\begin{array}{l}<40 \\
>10\end{array}$ & $\begin{array}{l}>40 \\
>10\end{array}$ \\
\hline $\begin{array}{l}\text { indice de } \\
\text { Grupo (IG) }\end{array}$ & 0 & 0 & 0 & 0 & 0 & $<4$ & $<4$ & $<8$ & $<12$ & $<16$ & $<20$ \\
\hline $\begin{array}{l}\text { Tipos de } \\
\text { material }\end{array}$ & $\begin{array}{r}\text { Frogi } \\
\text { de } p \\
\text { pedre } \\
e 0\end{array}$ & $\begin{array}{l}\text { nentos } \\
\text { edro, } \\
\text { equlho } \\
\text { ireio }\end{array}$ & $\begin{array}{l}\text { Areia } \\
\text { fino }\end{array}$ & & $\begin{array}{l}\text { iregulho } \\
\text { losos ou }\end{array}$ & $\begin{array}{l}\text { s e ore } \\
\text { orgilos }\end{array}$ & & $\begin{array}{l}\text { Solo } \\
\text { silto }\end{array}$ & $\begin{array}{l}\text { os } \\
\text { sos }\end{array}$ & $\begin{array}{l}\text { Sol } \\
\text { orgi }\end{array}$ & $\begin{array}{l}\text { os } \\
\text { losos }\end{array}$ \\
\hline $\begin{array}{l}\text { Classificaçōo } \\
\text { como subleito }\end{array}$ & \multicolumn{5}{|c|}{ Excelente a Bom } & \multicolumn{6}{|c|}{ Regular a mou } \\
\hline
\end{tabular}

NOTAS: $(1)-P_{10}, P_{40}$ e $P_{200}$ indicam, respectivamente os porcentagens que possom nas peneiros $n \circ 10(2 \mathrm{~mm}), 40(0,42 \mathrm{~mm})$ e $200(0,074 \mathrm{~mm})$.

(2) - LL e IP referem-se a froço passondo no 40.

(3) - Pora o subgrupo A-7.5:1P<LL-30 e pora o A-7-6:1P>LL-30.

(4) - A identificoção é feito do esquerdo poro direita, rozōo porque oA-3 é colocado ontes do A-2, sem que isto signifique superioridode doquele sobre este.

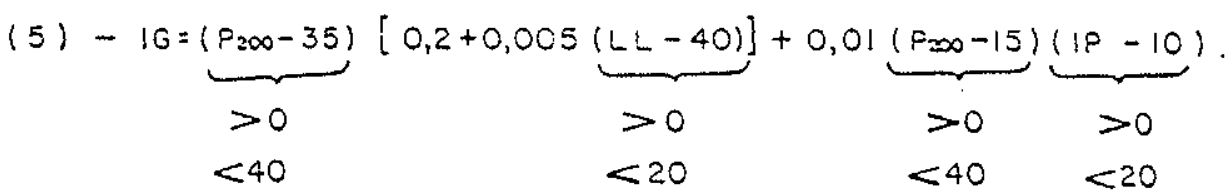

QUADRO 1 - Sistema de Classifícação H.R.B. (Highway Research Board) Fonte: CARUTO (1973). 


\subsubsection{Cartografia}

Os procedimentos para confecção do mapa geológico, geomorfológico e dos solos da área em estudo já foram descritos. Com relação, a metodologia para a elaboração do mapa potenciométrico, de vulnerabilidade dos aquíferos e de classes de declividade, tratar-seá a seguir:

\subsubsection{Mapa Potenciométrico}

Para a confeção do mapa potenciométrico, foram medidos os níveis potenciométricos em poços existentes na área de interesse do trabalho, bem como, considerado o levantamento geofísico executado.

Após o levantamento dos níveis potenciométricos, estes foram representados por linhas que unem pontos de mesma altura, usando método semelhante ao empregado em topografia. A equidistancia entre as linhas depende do número e distribuição espacial dos dados, inclinação da superficie potenciométrica e precisão das medidas (CUSTÓdTO e LLAMAS, 1983).

A configuração das linhas isopotenciométricas permite orientar o movimento da água via subterrânea, cuja direção está nas perpendiculares a essas linhas, no sentido das cotas mais baixas. As setas representadas no mapa potenciométrico configuram esse sentido de fluxo.

No mapa em questão, a equidistância adotada entre as linhas isopotenciométricas foi de 2,0 metros, tendo em vista a reduzida profundidade potenciométrica em uma grande porção da área estudada.

Na porção extrema oeste da área, não foram levantados os níveis potenciométricos em função da inexistência de poços e ser a região desprovida de estradas e caminhos, apresentando altas declividdes e geomorfologia acidentada. Contudo acreditamos, pelas características evidenciadas em campo, que haja um aumento da profundidade do nível potenciométrico a partir da última cota potenciométrica determinada, de 46 metros de profundidade.

\subsubsection{Mapa de Vulnerabilidade dos Aquiferos}

TALTASSE (1972) eleborou mapas de vulnerabilidade dos lençois aqúiferos da região do municipio de Campinas (S.P.), com a finalidade destes servirem como base para prognósticos sobre 
problemas de penetração e propagação de poluidores nos terrenos. Para estabelecer os Riscos a poluiçăo dos aqüiferos, esse autor baseu-se na litologia, hidrogeologia, porosidade de interstícios e fissuras das rochas.

Para a avaliação da vulnerabilidade natural do aqüifero FOSTER et al (1988) propõem serem analisados três parâmetros:

a) O tipo de ocorrência da água subterrânea.

b) As caracteristicas dos estratos acima da zona saturada, em termos de permeabilidade, granulometria e litologia.

c) Profundidade do nível da água.

Através dos dados disponíveis, neste trabalho adotamos a metodologia de FOSTER et al (1988) para a confecção do mapa de vulnerabilidade de aqüiferos. Neste mapa estão representadas áreas com alto, médio e baixo grau de vulnerabilidade.

Este mapa, em escala 1:50.000, após elaborado foi digitalizado através do emprego do S.G.I./SITIM do I.N.P.E.

\subsubsection{Mapa de Classes de Declividade}

A declividade dos terrenos é o fator básico condicionante para o escoamento superficial muito rápido, (DUARTE, 1980).

Além de controlar o escoamento e a infiltração de água, a declividade norteia a movimentação de massas e a estabilidade dos taludes, interferindo diretamente na adequabilidade de áreas para implantação de aterros sanitários.

A metodologia para a confecção de mapas de classes de declividades, já utilizada por vários autores, entre os quais DE BIASI (1970), BIGARELLA et al (1978), consiste em determinar em um mapa plani-altimétrico áreas de um mesmo intervalo de inclinação. Os limites dos intervalos são escolhidos antecipadamente, em função da variação de inclinação do terreno e da finalidade de uso do mapa, e transformados em distâncias entre as curvas de nível. Desta forma, as áreas de diferentes inclinações estarão limitadas por curvas de nível, e por segmentos transversais a elas. os comprimentos desses segmentos serão proporcionais aos limites de declividade antecipadamente escolhidos. 
No presente trabalho, as classes de declividade foram criadas a partir da digitalização das curvas de nível das folhas do Serviço geográfico do Ministério do Exército, SG.2-X-D-II-4, SG22-XD-V-2 e SG22-X-D-I-4, em escala 1:50.000, estando as curvas de nível equidistantes 20 metros, e da geração do Módulo Numérico do terreno M.N.T. em ambiente S.G.I., formato RASTER.

o produto gerado com intervalos de declividade correspondentes a 0-58, 5-108, 10-15\%, 15-208 e superior a 20\%, foi editado, e plotado na H.P. $650 \mathrm{C}$ jato de tinta.

4.2.4.4. Mapa de Caracterização das Áreas para a Implantação de Aterros Sanitários

Para a elaboração do mapa de caracterização das áreas para a implantação de aterros sanitários foram interrelacionados dois grupos de informaçōes.

o primeiro grupo foi gerado pelo estudo integrado da área de interesse do trabalho, cotejando o quadro geológico, geomorfológico, a classificação dos solos e características do nível potenciométrico e de vulnerabilidade dos aqüiferos.

- segundo grupo é representado pelo contido nas N.B.R. -8438 (A.B.N.T., 1984), N.B.R. -8419 (A.B.N.T., 1984), N.B.R. -8849 (A.B.N.T., 1985), bem como, nas normas da C.E.T.E.S.B. (1983 e 1985). Neste mapa estão representadas as áreas favoráveis a implantação de aterros sanitários, as áreas favoráveis a implantação de aterros sanitários com restrições e áreas desfavoráveis a implantação de aterros sanitários. Quando a área for favorável com restrições, na legenda do mapa estarão descritas as restrições, bem como, para as áreas desfavoráveis, na legenda, constará os fatores de inadequação.

Este mapa, em escala 1:50.000, após elaborado foi digitalizado através do uso do software S.G.I./S.I.T.I.M. do I.N.P.E.

\subsubsection{Digitalização dos Mapas}

A digitalização dos mapas foi efetuada devido a facilidade de atualização futura dos dados neles contidos, praticidade no arquivamento e simplicidade para obtenção de novas cópias, se desejadas. 
Para a digitalização foram empregados os seguintes equipamentos:

- Microcomputador P.C.-A.T. 486 Clock 33 Megahertz com 16 Mb, de memória RAM e HD de 250 Mb de capacidade armazenadora;

- Monitor colorido J.V.G.A.-19 polegadas marca VIDEOTEK;

- Mesa digitalizadora - DIGIGRAE, modelo Van Gogh-A1;

- Processador gráfico T.M.S.34010 40/60 Mhz (Engespaço);

- Ploter H.P. 650C. jato de tinta.

Os mapas temáticos foram digitalizados através do emprego do Sistema Geográfico de Informações - S.G.I./S.I.T.I.M. desenvolvido pelo Instituto Nacional de Pesquisas Espaciais - I.N.P.E. (ENGEsPAÇO, 1989).

Cada tema foi digitalizado em diferentes planos de informação (P.Is.), os quais deram origem aos mapas temáticos através de plotagem.

4.2.5. Método de Avaliação da Situação Atual da Disposição dos Resíduos Sólidos Urbanos em Paranaguá

Para esta avaliação, foi efetuado um levantamento da quantidade e da caracterização física do lixo urbano gerado em Paranaguá, tendo como base a N.B.R.-10.004 (A.B.N.T., 1987) e N.B.R.10.007 (A.B.N.T., 1987). Essas normas tratam da classificação dos resíduos sólidos e da amostragem destes, respectivamente.

Foram também identificadas as fontes geradoras de lixo em Paranaguá, tendo em vista a responsabilidade sobre o lixo gerado por indústrias, hospitais, aeroportos e outras entidades, estabelecidas pela Resolução no 5 (CONAMA, 1993).

Em seguida, foi elaborada uma análise preliminar sobre as características do meio físico do local onde se encontram os depósitos de lixo de Paranaguá, abordando os parâmetros exigidos pela N.B.R. -8419 (A.B.N.T., 1984) e N.B.R.-8849 (A.B.N.T., 1985), que tratam sobre apresentação de projetos para aterros sanitários de residuos sólidos urbanos. 
4.2.6. Método de Avaliação das Áreas Adequadas para a Implantação de Aterros Sanitários

As exigências para a apresentação de projetos relativos a instalação de aterros sanitários, estão expressas em normas e legislação pertinentes.

As normas da Associação Brasileiras de Normas Técnicas, fixam condições para apresentação de projetos de aterros de resíduos industriais perigosos (N.B.R.-8418 - A.B.N.T., 1984), projetos de aterros sanitários de resíduos sólidos urbanos (N.B.R.-8419 A.B.N.T., 1984) e projetos de aterros controlados de resíduos sólidos urbanos (N.B.R. -8849 - A.B.N.T., 1985).

A legislação federal estabelece na Portaria no 53 de 01/03/79 normas para os projetos específicos de tratamento e disposição final de resíduos sólidos, bem como a fiscalização de sua implantação.

Além dessas exigências, existem as normas da CETESB (1983 e 1985) que definem critérios para implantação de aterros sanitários e sobre a disposição de resíduos sólidos industriais, respectivamente. outras exigências para aterros de residuos sólidos domiciliares e industriais estão contidas no manual de critérios e exigências de EIA/RIMA da Secretaria do Meio Ambiente de São Paulo.

Essas normas, critérios e leis foram analisadas de forma a permitir a avaliação das áreas para a implantação de aterros sanitários.

Conjuntamente com essas normas, critérios e leis, foram consideradas as características do meio físico, representadas nos mapas geológico, geomorfológico, de solos, de classes de declividades, potenciométrico e de vulnerabilidade natural dos aquíferos.

Assim, as características desejáveis das áreas para implantação de aterros sanitários no local em estudo, estão descritas a seguir:

a)

Acessos

- acesso a área destinada a um aterro sanitário, devido ao fluxo de caminhões de lixo, deve permitir trânsito em qualquer época do ano, sob condições climáticas variáveis. 
b)

Geologia

Do embasamento geológico irá depender os componentes dos materiais alterados que originarão os solos e, as caracteristicas de permeabilidade, granulometria e tipo de solo do local.

Além desses fatores, ressalta-se a necessidade do conhecimento das estruturas geológicas, que podem se constituir em locais de infiltração de líquidos ou condutos para cursos de água, manguezais e oceanos. Desta forma, é imprescindível a determinação do tipo, da abrangência e das atitudes dessas estruturas.

Portanto, os melhores locais para a locação de aterros sanitários sob o aspecto geológico, devem apresentar rochas que alteradas produzam solos recomendáveis para esse propósito e, não possuam estruturas que possibilitem infiltrações.

c)

Hidrogeologia

A proteção da água de subsuperficie é fundamental na construção de um aterro sanitário. Assim, a base do aterro deve estar bem acima do nível do lençol freático, considerando a sua posição mais elevada.

A CETESB (1985), faz menção a uma espessura mínima de camada insaturada entre o nível mais elevado do lençol freático e a parte inferior do aterro de 1,50 metros e recomenda como adequada a espessura de 3 metros. Contudo, a N.B.R.-1057 (A.B.N.T., 1987) cita como adequada à espessura de 1,50 metros de solo insaturado entre 0 lençol freático e a superficie inferior de aterros para resíduos perigosos.

Tendo em vista, as caracteristicas hidrogeológicas da área em estudo, adotar-se-á como critério uma profundidade mínima de 2,0 metros entre a base do aterro, ou seja, a superfície, e o nível potenciométrico dos aquíferos. Esta opção é justificada pela característica de baixa permeabilidade dos solos, a serem usados como substrato, dos locais apropriados à implantação de aterros sanitários, fator que garante maior tempo de trânsito e, a retenção dos percolados. 
d)

Geomorfologia

A caracterização fisiográfica de uma área apropriada para a locação de aterros sanitários, segundo a CETESB (1985), é de apresentar pouca declividade, ausência de depressões e não ser sujeita a inundações.

As declividades baixas, possibilitam menores riscos com relação a movimentos de massas superficiais, bem como, diminuem as chances de aparecimento de fluxos capazes de revolver o lixo.

A ausência de depressões, visa impedir acúmulos de água que venham afetar o aterro, ou tornar possivel acumulação indevida de chorume.

A possibilidade de inundação nessas áreas é indesejável, pois, aumentaria o risco de infiltração e disseminação de elementos potencialmente poluentes.

A N.B.R.-1057 (A.B.N.T., 1987), recomenda declividades de 18 - 208, tendo como condicionantes as obras de terraplanagem a serem efetuadas no local do aterro sanitário.

Adotar-se-á como critério para a área em estudo declividades de até 108 como limite para instalação de aterros sanitários, em função das distribuições das classes de declividade nos locais de interesse.

e)

Solos

A caracterização dos tipos de solos, na escolha da área mais apropriada para locação de aterros sanitários, segundo a CETESB (1985), consiste em determinar o teor de argila, o indice de plasticidade e a permeabilidade dos mesmos.

Assim, os locais mais adequados da área em estudo para locação de aterros sanitários, devem apresentar solos com bom teor de argila, indice de plasticidade maior ou igual a 15 unidades e coeficiente de permeabilidade inferior a $1 \times 10^{-4} \mathrm{~cm} / \mathrm{s}$.

Os solos da área passíveis de serem usados como impermeabilizantes ou para a cobertura do lixo devem apresentar porcentagem superior a 308 de particulas passando na peneira nㅇ 200, limite de liquidez maior ou igual a 30\%, indice de plasticidade maior ou igual a 15 unidades e p.H. igual ou maior que 7,0 segundo a CETESB (1985). 
f)

Cobertura Vegetal

A vegetação pode atuar como elemento redutor da erosão, da formação de poeira e transporte de odores, em locais de implantação de aterros sanitários (N.B.R.-10157 - A.B.N.T., 1987).

A caracterização da vegetação, além dos propósitos acima mencionados, deve levar em consideração as espécies de valor econômico, de valor científico, as raras em processo de extinção e aquelas importantes para o equilibrio faunistico e do meio ambiente. Isto se deve ao fato da possibilidade de corte ou da provável deteriorização da vegetação em áreas de aterros sanitários.

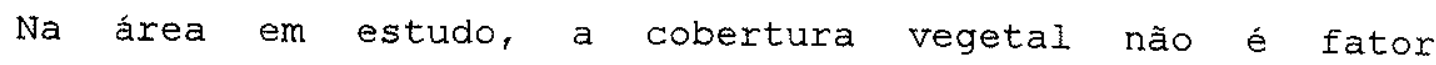
limitante, pois, a grande maioria das espécies podem ser usadas como cerca viva arbustiva ao redor de aterros sanitários, auxiliando o isolamento e reduzindo o impacto ambiental.

g)

Hidrografia

A CETESB (1985) recomenda que um aterro deve ser localizado a uma distância mínima de 200 metros de qualquer rio ou qualquer fonte de abastecimento de água.

A N.B.R.-10157/87, afirma que essa distância poderá ser alterada pelo Órgão Estadual de Controle Ambiental.

Adotou-se $\circ$ critério de distanciamento de 200 metros de rios, poços ou outras fontes de abastecimento d'água, atentando principalmente para zoneamento dos rios da região.

h) Direção Predominante dos Ventos

os ventos predominantes devem soprar em direção oposta a centros urbanos e pequenos núcleos habitacionais, pois, os odores desagradáveis e a poeira gerada na operacionalização do aterro, devem ser direcionados para locais onde não causem deteriorização da qualidade do ar e, possíveis doenças respiratórias.

Em Paranaguá, como já evidenciamos anteriormente, a direção predominante dos ventos é sul e sudeste, ou seja, ventos provenientes do mar.

Nessa região os centros urbanos principais, localizam-se na orla costeira, havendo diminuta concentração populacional mais a oeste. Observa-se também que o limite oeste do município é feito 
pelas elevações da zona montanhosa litorânea, seguida pela serra do Mar.

Desta forma, os ventos não configuram fator limitante na área em estudo, tendo em vista soprarem do mar. 
5.

RESULTADOS E DISCUSSÃO

5.1. Análise da situação atual da disposição dos resíduos sólidos em Paranaguá

A conceituação de residuo sólido é expressa na N.B.R.-10004 (A.B.N.T., 1987) como sendo os resíduos em estado sólido e semisólido, que resultam de atividades da comunidade de origem: industrial, doméstica, hospitalar, comercial, agrícola, de serviços e varrição. Ficam incluídos nesta definição os lodos provenientes de sistemas de tratamento de água, aqueles gerados em equipamentos e instalações de controle de poluição, bem como determinados líquidos cujas particularidades tornem inviável o seu lançamento na rede pública de esgotos ou corpos de água, ou exijam para isso soluções técnicas e economicamente inviáveis, em face à melhor tecnologia disponível.

Essa mesma norma, divide os resíduos sólidos em três classes, quanto ao potencial de risco ao meio ambiente e à saúde pública, da seguinte maneira:

a) Resíduos classe I - perigosos: são os resíduos sólidos que em função de suas características de inflamabilidade, corrosividade, reatividade, toxidade e patogenicidade, podem apresentar riscos à saúde pública ou acarretar danos ao meio ambiente, quando manipulados ou dispostos de forma inadequada.

b) Residuos classe II - não inertes: são os resíduos que não se enquadram na classe I - perigosos ou na classe III inertes.

c) Resíduos classe III - inertes: são os resíduos sólidos que submetidos ao teste de solubilização (N.B.R.-10006 A.B.N.T., 1986) não tenham nenhum de seus constituintes solubilizados, a concentrações superiores aos padrões de potabilidade de água, conforme a listagem no 8 (Padrões para - teste de solubilização).

Os residuos gerados nos portos, aeroportos, terminais ferroviários e rodoviários e estabelecimentos prestadores de serviços 
de saúde são classificados na Resolução no 5 (CONAMA, 1993), nos seguintes grupos:

a) Grupo A: resíduos que apresentam risco potencial à saúde pública e ao meio ambiente devido a presença de agentes biológicos. Incluem-se neste grupo animais usados em experimentação, sangue e hemoderivados, bem como, todos os materiais ou alimentos que estiverem em contato com ambientes hospitalares, unidades ambulatoriais ou laboratórios de análises clínicas. Enquadram-se, ainda, neste grupo os objetos perfurantes ou cortantes proveniente de estabelecimentos prestadores de serviços de saúde.

b) Grupo B: resíduos que apresentam risco potencial à saúde pública e ao meio ambiente devido a suas caracteristicas químicas. Enquadram-se neste grupo as drogas quimioterápicas e os resíduos farmacêuticos.

c) Grupo c: rejeitos radioativos. Incluem-se neste grupo os materias radioativos ou os contaminados por radioatividade.

d) Grupo D: resíduos comuns. Aqueles residuos que não se enquadram nos grupos descritos anteriormente.

Os resíduos sólidos urbanos, são definidos na N.B.R.-8419 (A.B.N.T., 1984) e N.B.R.-8849 (A.B.N.T., 1985), como os resíduos sólidos gerados num aglomerado urbano, excetuando-os resíduos industriais perigosos, hospitalares sépticos e de aeroportos.

5.1.1. Levantamento da Qualidade, Quantidade e Classificação dos Resíduos sólidos produzidos

segundo o levantamento censitário de 1991 realizado em Paranaguá, a população do município é de aproximadamente 107.601 habitantes, destes aproximadamente 94.632 configuram a população urbana e, nos meses de dezembro, janeiro e fevereiro, a densidade populacional atinge 190.000 pessoas.

OBLADEN (1993), propondo racionalizar a coleta e o transporte dos resíduos urbanos do município, estimou em 23,250 toneladas/dia a quantidade de resíduos sólidos coletados na rede municipal, bem como, em 0,943 tonetaldas/aia a quantidade de lixo 
hospitalar gerado, sendo que destes 0,650 toneladas/dia são coletados.

Considerando os parâmetros sobre a quantidade de residuos gerados individualmente no município, pelo autor antes mencionado, como sendo de $0,400 \mathrm{~kg}$, pode-se estimar a quantidade de lixo urbano produzido diariamente em 37,852 toneladas/dia e durante os meses de dezembro, janeiro e fevereiro em 76,000 toneladas/dia (Tabela 1). Verifica-se, portanto, que apenas 61,42 do lixo gerado diariamente é coletado.

Com relação a caracterização física do lixo urbano gerado, procedeu-se a uma amostragem quantitativa aproximada do conteúdo de dez caminhões, durante a descarga do lixo em dois lixões e, obteve-se as seguintes incidências médias de materiais:

- Materiais inorgânicos:

$\begin{array}{lr}\text { Papelão } & 3,08 \\ \text { Papel } & 7,08 \\ \text { Plásticos } & 6,08 \\ \text { Latas } & 4,08 \\ \text { Vidros } & 3,08 \\ \text { Metais diversos } & 1,58 \\ \text { Materiais orgânicos } & 508 \\ \text { Entuihos em geral } & 258\end{array}$

As fontes geradoras de lixo em Paranaguá são representadas por residencias, estabelecimentos comerciais, hospitalares e públicos, e ainda, pelo porto, aeroporto e um reduzido número de pequenas indústrias.

A coleta dos resíduos sólidos por essas fontes é efetuada sem distinção do tipo de lixo gerado, excetuando-se o lixo hospitalar que possue um sistema particularmente de coleta e destinação final.

Esse procedimento de coleta sem distinção do tipo de lixo, contraria o Artigo $4^{\circ}$ da Resolução n 5 (CONAMA, 1993), que atribue 0 gerenciamento dos resíduos sólidos, desde a geração até a disposição final para os estabelecimentos geradores do lixo, qual sejam, portos, aeroportos e estabelecimentos de saúde. 
- lixo hospitalar, antes referido, é gerado por sete hospitais, nove farmácias e cinco postos de saúde.

Uma amostragem qualitativa desses residuos hospitalares, efetuada no depósito de Alexandra-Matinhos, demonstrou 0 seguinte conteúdo: agulhas e seringas, fraldas geriatricas, frascos de plástico de soro, algodão e gaze usados, frascos de remédios vazios e sacolas plásticas.

As caracteristicas desses resíduos e a maneira como estão dispostos, indicam completa inobservância da resolução no 05 (CONAMA, 1993), que trata sobre a disposição final e tratamento prévio destes tipos de resíduos. 


\begin{tabular}{|c|c|c|c|c|c|c|c|}
\hline \multicolumn{2}{|c|}{ POPULAÇAO URBANA } & \multicolumn{2}{|c|}{$\begin{array}{c}\text { LIXO URBANO GERADO } \\
\text { EM TON/DIA }\end{array}$} & $\begin{array}{c}\text { LIXO COLETADO EM } \\
\text { TON/DIA }\end{array}$ & DE LIXO COLETADO \\
\hline MAIO & DEZEMBRO & MAIO & DEZEMBRO & MAIO & DEZEMBRO & MAIO & DEZEMBRO \\
A & A & A & A & A & A & A & A \\
NOVEMBRO & FEVEREIRO & NOVEMBRO & FEVEREIRO & NOVEMBRO & FEVEREIRO & NOVEMBRO & EEVEREIRO \\
\hline 94.632 & 190.000 & 37,852 & 76,000 & 23,250 & - & 61,42 & - \\
\hline
\end{tabular}

TABELA 1 - Quantidade de lixo urbano em toneladas/dia gerado em Paranaguá.

Fonte: Modificado de OBLADEN (1993). 
Existe uma grande quantidade de lixo, gerado pela atividade comercial que desenvolveu-se sobremaneira no municipio em função do porto.

As atividades industriais em Paranaguá são diminutas, destacando-se as indústrias de esmagamento de soja, misturadoras de fertilizantes e as refinadoras de sal. Em menor número existem indústrias téxteis, mecânicas, metalúrgicas e extrativas de minerais.

A destinação final dos residuos sólidos produzidos por essas indústrias, muitas vezes é feita na área da própria empresa, ou no caso de pequenas indústrias situadas na região urbana, os resíduos são coletados juntamente com o restante do lixo urbano.

Não existem análises químicas dos residuos dos depósitos de Paranaguá, tampouco amostragem de acordo com a N.B.R.-10007 (A.B.N.T., 1987) que fixa as condições para amostragem, preservação e estocagem de amostras de resíduos sólidos.

Assim, tendo como base a análise física efetuada e, as caracteristicas enumeradas pela N.B.R.-10004 (A.B.N.T., 1987) que classifica os resíduos sólidos quanto a seus riscos potenciais ao meio ambiente e a saúde pública, os resíduos sólidos dos depósitos de Paranaguá podem ser classificados como da Classe III, ou inertes. Exceção deve ser feita aos residuos hospitalares, destinados ao depósito de Alexandra-Matinhos, com respeito a patogenicidade, sendo que as agulhas e outros objetos ali lançados podem conter microorganismos capazes de produzir doenças. Portanto, esses resíduos hospitalares devem ser considerados da Classe I, ou perigosos.

5.1.2. Os Depósitos de Resíduos Sólidos do Município de Paranaguá os depósitos de resíduos sólidos recebem várias denominações com diferentes conceituações, existindo portanto a necessidade de conceituação dos mesmos.

A N.B.R. -8849 (A.B.N.T., 1985), classifica aterro controlado de resíduos sólidos urbanos como a disposição de resíduos sólidos urbanos no solo, sem causar danos ou riscos a saúde pública e à sua segurança, minimizando os impactos ambientais confinando os resíduos sólidos com materiais inertes através de cobertura. 
Esse tipo de depósito de resíduos sólidos apresenta um certo grau de controle, contudo, segundo RISSO (1994) esta longe de se enquadrar aos critérios necessários à um aterro sanitário.

- aterro sanitário é uma alternativa de disposão final de residuos sólidos no solo, que usa técnicas da engenharia para confinar o lixo na menor área possível e utiliza uma metodologia que preserva o meio ambiente e protege a saúde pública (FUzZARo, 1994).

- aterro sanitário exige, portanto, uma série de critérios com respeito a seleção da área, construção e posteriores técnicas de operação.

Assim, os aterros sanitários são projetados para receberem resíduos urbanos e alguns residuos industriais não perigosos, portanto, são enviados a eles somente os residuos classificados como Classe II e III (RISSO, 1994).

- Lixão consiste apenas no despejo dos residuos no solo, sem nenhum critério técnico ou tratamento prévio.

os resíduos sólidos gerados em Paranaguá, são destinados a quatro áreas. Nesses locais o lixo é depositado a céu aberto, havendo ocorrência de odores desagradáveis, presença de vetores nocivos e, em alguns locais existência de chorume em superfície.

Assim, esses locais configuram verdadeiros lixões, e potencialmente são poluentes, pois não apresentam locação e operação adequados.

Um dos depósitos de lixo, o menor entre os quatro existentes, localiza-se na ilha de Valadares, os outros localizam-se no continente. (Figura 7).

o depósito de lixo hospitalar encontra-se aproximadamente a $1,8 \mathrm{~km}$ do cruzamento da rodovia BR 277 e PR-508. O depósito de destino do lixo das praias localiza-se na praia de Shangrilá, situando-se aproximadamente a $2,5 \mathrm{~km}$ oeste da rodovia $P R-412$. Na região do Embocuí, situada ao norte da rodovia BR-277, próxima a zona urbana da cidade de Paranaguá, encontra-se o depósito para o qual se destina o lixo da sede municipal. 

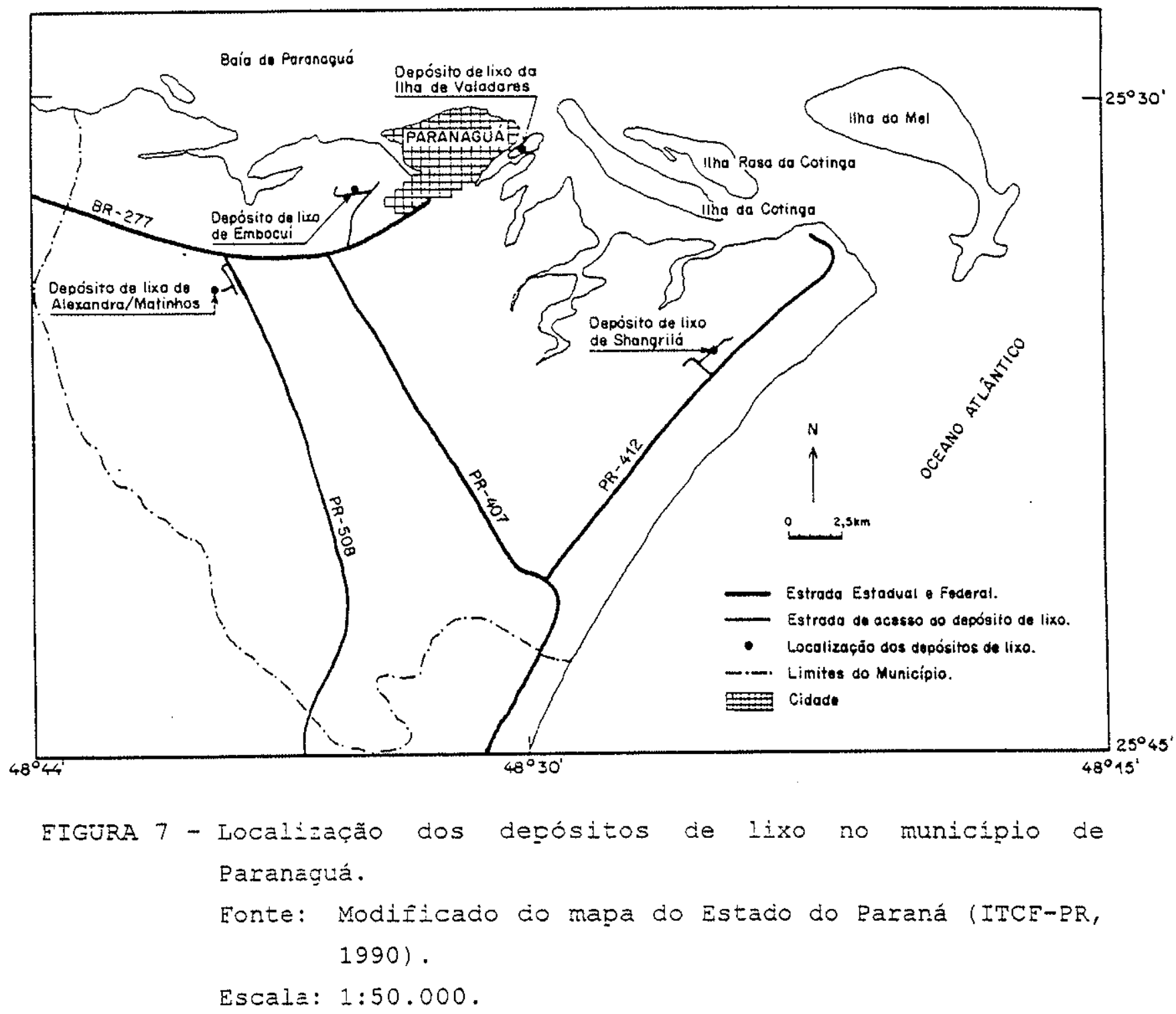
5.1.2.1. O Depósito de Lixo da Ilha de Valadares

- Localização

Encontra-se a sudeste na ilha de Valadares, junto ao núcleo habitacional, distante aproximadamente 100,0 metros do rio Itiberê (Figura 8). Esse local apresenta-se coberto parcialmente por gramíneas e vegetação arbustiva de pequeno porte, que em grande parte foram soterradas por Iixo.

- acesso ao depósito é feito por estreitas ruas sem pavimentação e o transporte do lixo é efetuado por carroças de pequeno porte, ou pelos próprios geradores do lixo que habitam as cercanias. (Eotografia 1 ).

- Geologia

o substrato geológico da área onde se encontra o depósito é representado por sedimentos arenosos de origem marinha que situam-se próximos a manguezais de idade holocênica.

- Geomorfologia

As altitudes máximas na ilha de Valadares atingem 9 metros e, o depósito de lixo encontra-se aproximadamente a 2,0 metros do nível das águas do rio Itiberê.

- local é plano e sujeito a invasão de águas com a subida da maré, ou das águas do rio Itiberê.

- Hidrogeologia

A profundidade do lençol freático, verificado em poços tipo cacimbas, no local é inferior a 2,0 metros e no depósito ocorre água a nível do solo, junto com os residuos depositados (Fotografia 2). Características que permitem a poluição do lençol freático.

- Hidrografia

- distanciamento aproximado de 100,0 metros do rio Itiberê, configura a situação ideal para carreamento do chorume ou, do próprio lixo em direção ao rio. Isto gera condições para a poluição do rio em questão.

- rio itiberê é considerado de classe II pela portaria $n^{\circ}$ 05/89 da SURHEMA, estando portanto, sujeito aos limites das substâncias potencialmente prejudiciais até certos teores máximos, os quais dificilmente serão mantidos com a presença de um depósito de lixo tão próximo ao rio. 




$5 \div-\div$ Sedimento-areno-sítico-argiloso.

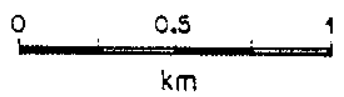

$==-1$ Mangue.

$\because \because$ Sedimento orenoso.

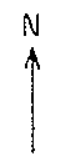

Fonte: Folna topográfica de Paranaguá (SG-22-X-D-V-2);

Folha topográfica de llha do Mel (SG-22-X-D-VI-1).

FIGURA 8 - Mapa de localização do depósito de resíduos sólidos da ilha de Valadares. 

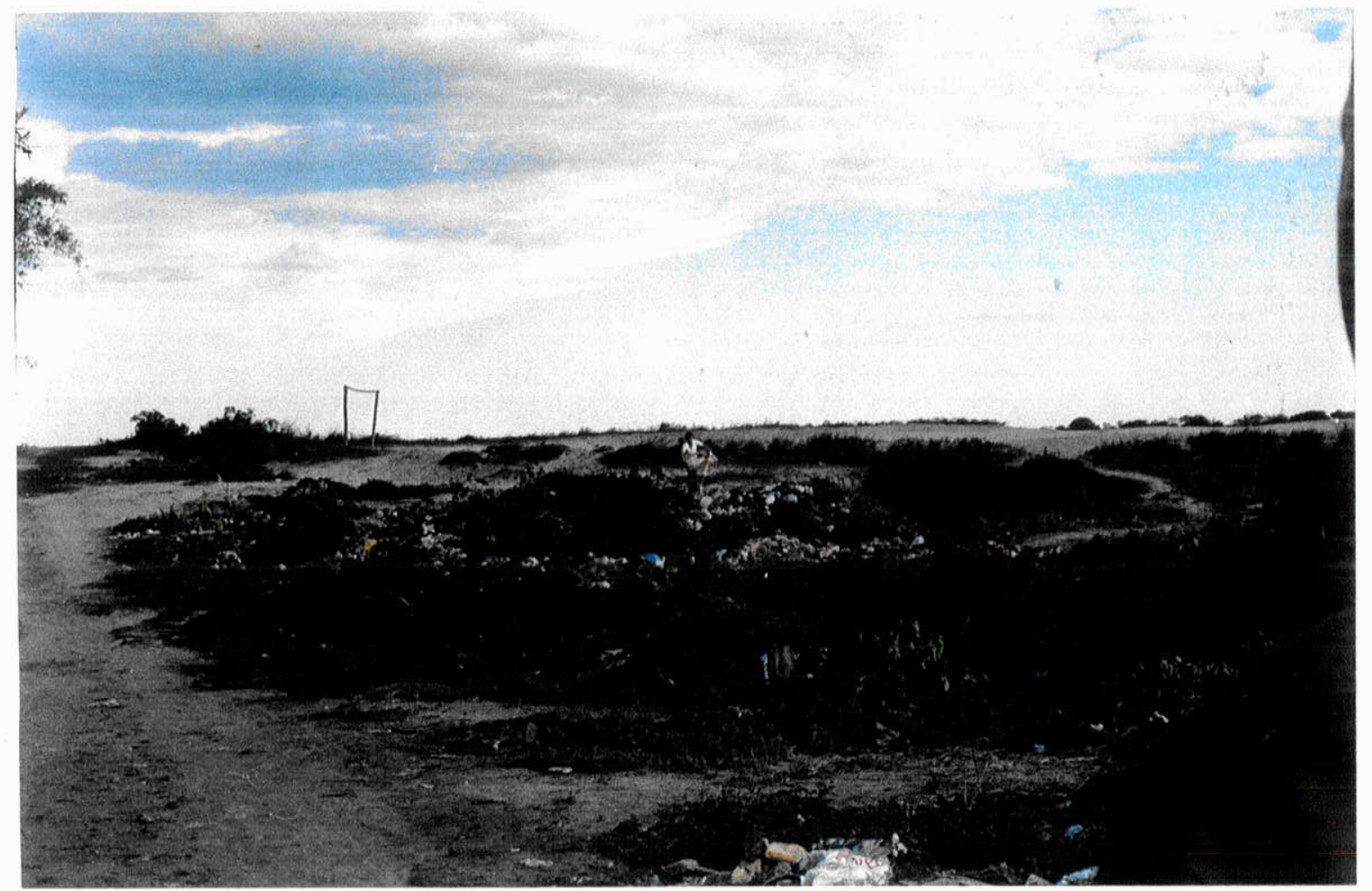

FOTOGRAFIA 1 - Flagrante de um morador jogando lixo no depósito da ilha de Valadares. 


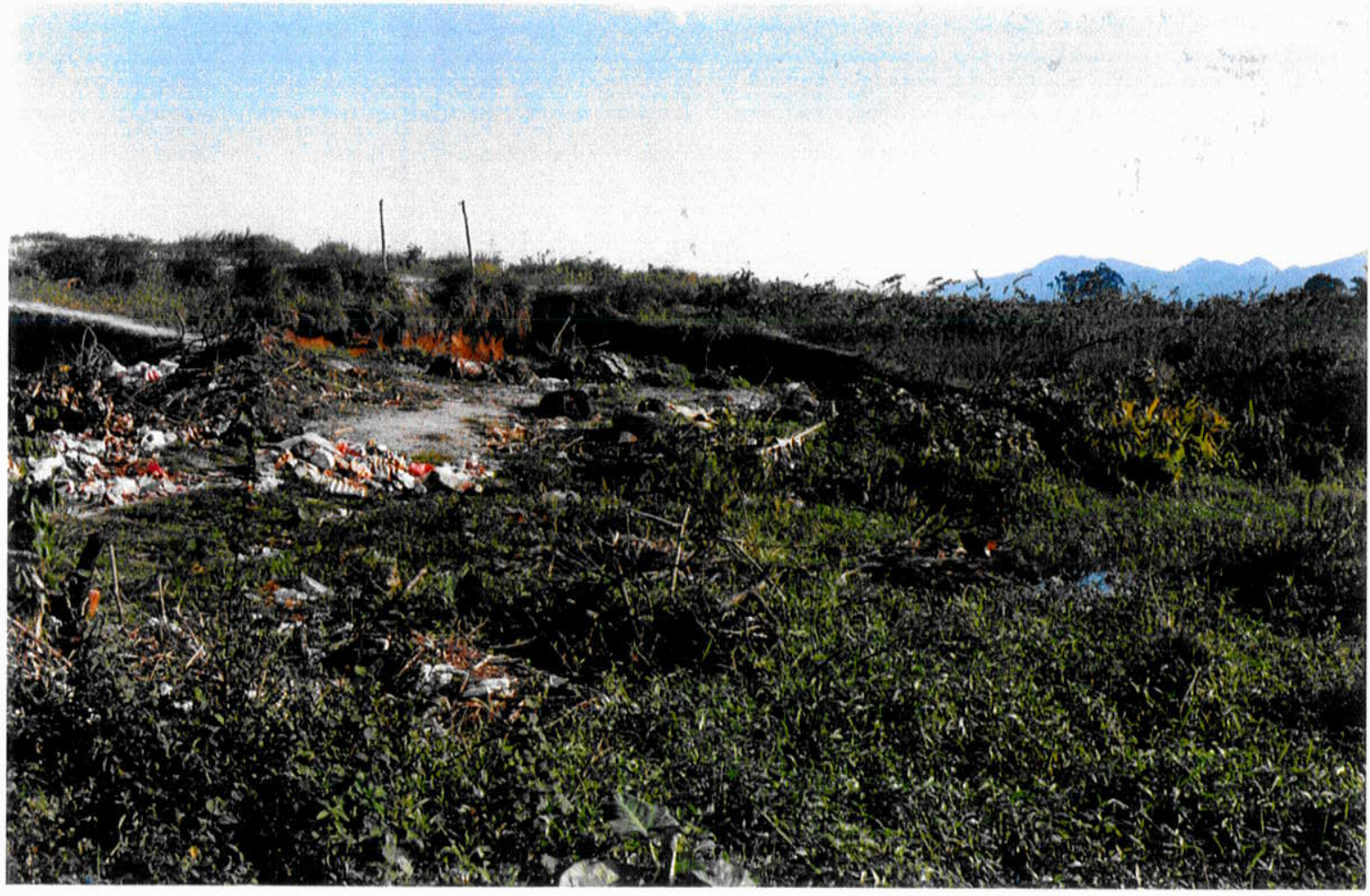

FOTOGRAFIA 2 - Ocorrência de afloramento de água junto com o lixo na ilha de Valadares. 
- Pluviosidade

Os altos indices pluviométricos e a grande amplitude de distribuição de chuvas, aliadas as condições geomorfológicas locais, criam condições ideais para o transporte e infiltração de elementos poluentes.

As enxurradas podem transportar $\circ$ lixo ou os elementos gerados de sua decomposição para dentro do rio próximo.

A infiltração, que se opera intensamente, pela situação local em função do solo arenoso e encharcamento permanente, é acelerada nos períodos de chuvas intensas quando existe um saldo positivo do balanço hídrico.

- Método de operação

Inexiste método de operação, configurando ao depósito as características de um lixão.

- Estimativa de Vida útil

observando as caracteristicas fisiográficas locais, nota-se que a topografia é suave, porém a dimensão da área livre para colocação do lixo é restrita, implicando em uma curta vida útil para - depósito.

Este fator certamente favorecerá ao abandono dessa área, como depósito de lixo, em pouco espaço de tempo e o aparecimento de um novo lixão na ilha.

- Impactos Ambientais e Sanitários

Apesar do depósito de lixo ter pequenas dimensões, ocorre no local mau cheiro e a presença excessiva de moscas, que infestam as casas próximas.

A poluição hídrica superficial é facilmente observada e, a poluição do lençol freático é certa, tendo em vista as características locais de solo e acúmulo de água.

5.1.2.2. O Depósito de Lixo de Alexandra-Matinhos

- Localização

Situa-se próximo ao cruzamento da rodovia Alexandra-Matinhos (PR-508) e BR-277, e seu acesso é feito através de uma estrada secundária, perfazendo aproximadamente $1,8 \mathrm{~km}$ do referido cruzamento rodoviário. (Figura 9). 


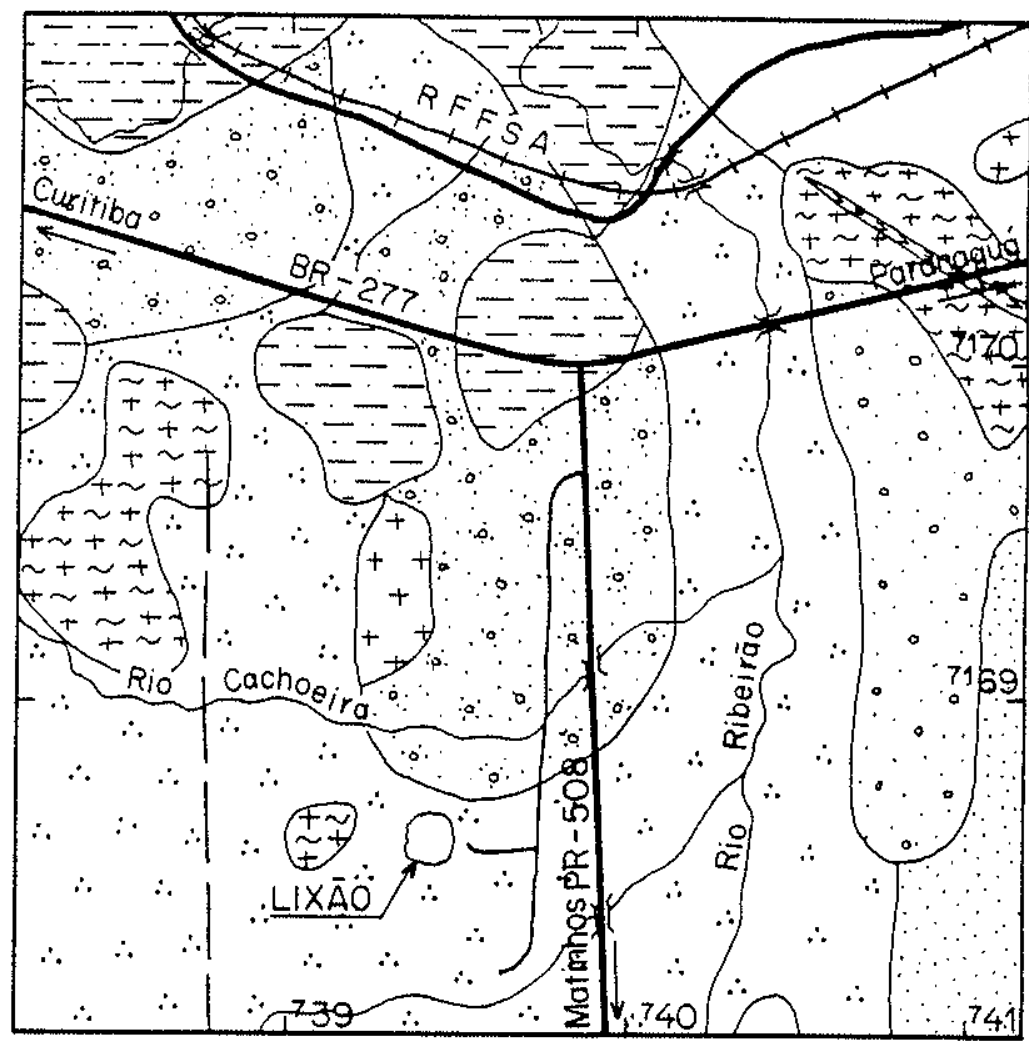

$=-2$ Mangue.

$\because \because \therefore \therefore$ Aluvião.

$\therefore \because$ Sedimento arenoso.

Cascalho.

Fm. Alexandra.

क्य Dique.

$\left[\begin{array}{l}+ \\ ++++\end{array}\right.$

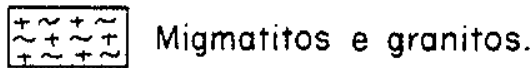
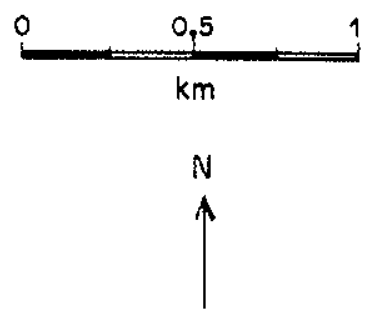

Fonte: Folha topográfica de Paranaguá (SG-22-X-D-V-2).

EIGURA 9 - Mapa de localização do depósito de resíduos sólidos de Alexandra-Matinhos. 
A estrada secundária, sem pavimentação, apresenta um curto trecho de difícil transposição quando chove. Neste trecho foram observadas pequenas quantidades de lixo caído dos caminhões durante seu transporte.

Próximo a este depósito, constituido por lixo hospitalar existem duas habitações cujos moradores convivem com os perigos potenciais dos resíduos sólidos aí depositados.

A vegetação local é composta por macega agreste e pequenas árvores, que foram arrancadas para abrir espaço para o lixo.

- Geologia

- local apresenta sedimentos aluviais, com predominância argilosa relacionados a processos de fluxo de baixa densidade que transportam e depositam sedimentos finos. Os materiais finos depositados são oriundos das regiões mais elevadas, provinientes da decomposição de granitos. Segundo BULL (1972), esses depósitos são de dificil separação em afloramentos devido ao fato das dimensoes dos canais excederem os dos afloramentos.

- Geomorfologia

A área é plana, possuindo altitudes máximas de 10 metros, e configurando uma região de altitudes médias. Nas cercanias, ocorrem pequenas elevações com altitudes próximas a 30 metros, que se distanciam entre 50 metros e 200 metros do depósito.

A topografia plana, permite concentrações localizadas de águas superficial, após chuvas excessivas. (Fotografia 3).

- Hidrogeologia

A características do solo mais argiloso, talvez não represente uma situação extremamente critica com relação aos elementos poluidores que possam atingir o lençol freático. Porém, há que considerar o volume de água concentrada em épocas mais chuvosas que produzem carga considerável sobre esse solo, alterando sua permeabilidade, bem como a periculosidade do lixo depositado. 


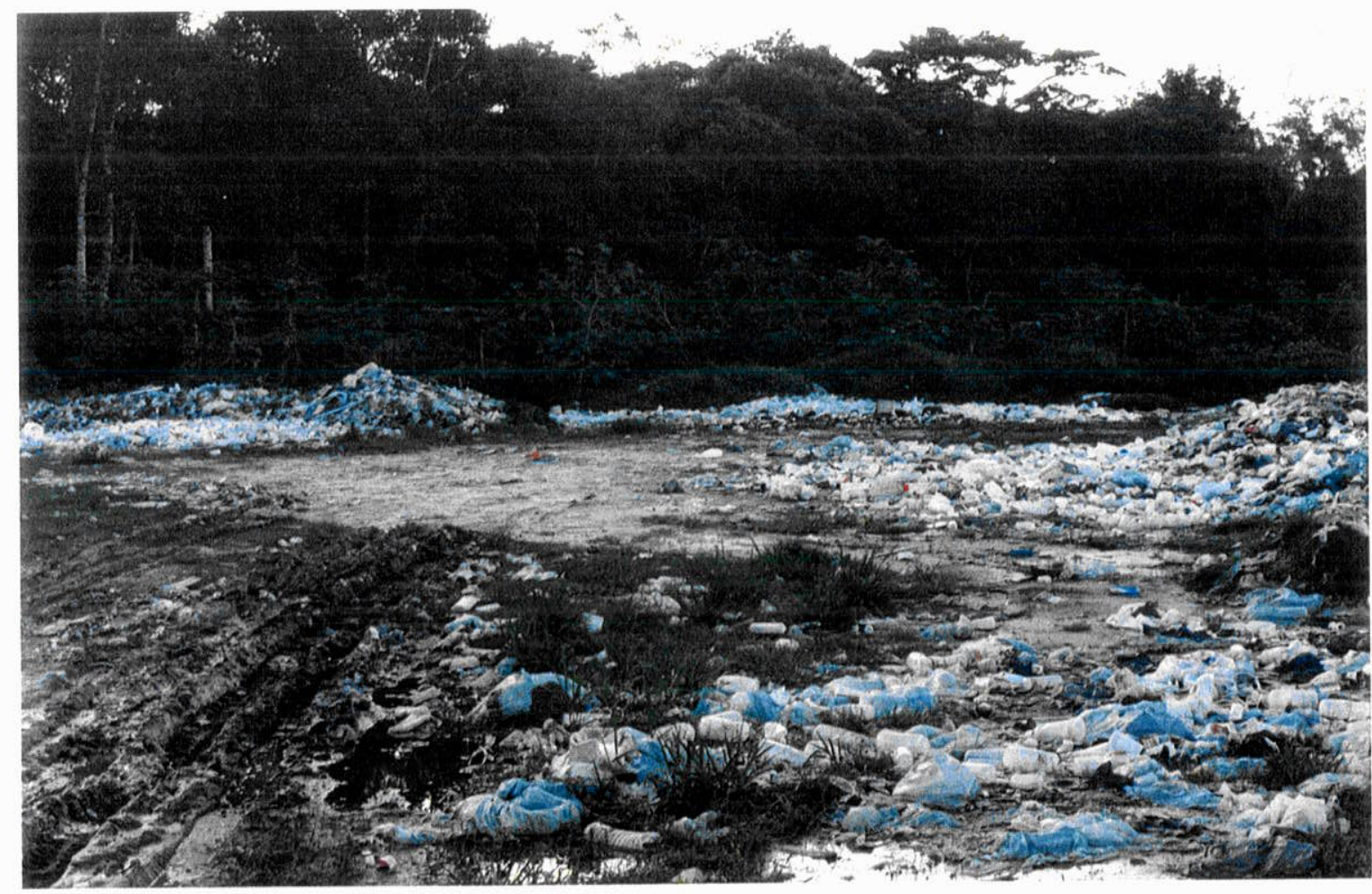

FOTOGRAFIA 3 - Concentração de água no depósito hospitalar, após chuvas excessivas. 
- Hidrografia

- depósito encontra-se na bacia hidrográfica do rio Cachoeira. Este rio, após passar nas proximidades do depósito, a jusante forma o rio Ribeirão que antes de desaguar na Baía de Paranaguá, constitue extensa região de mangue.

Assim, ocorre o risco potencial da poluição do rio Ribeirão, bem como, de larga faixa de mangue e da baśa de Paranaguá.

- Pluviosidade

A situação próxima a elevações, predispõe $\circ$ local do depósito aos riscos das enxurradas. Essas enxurradas provocariam o transporte ou o revolvimento dos resíduos depositados, possibilitando também, disseminação de elementos poluentes e acelerando a provável poluição do lençol freático.

- Método de Operação

- lixo é simplesmente descarregado dos caminhões, não havendo posteriormente operação alguma (Eotografia 4).

- Estimativa de Vida útil

o segmento de área onde está localizado o depósito de lixo de alexandra-Matinhos, possibilita estimar uma vida útil de média duração.

Porém, é necessário considerar a falta de dados sobre o solo e profundidade do lençol freático, fatores que podem determinar o abandono desta área para disposição final de lixo.

- Impactos Ambientais e Sanitários

A área tem como inconveniente a possibilidade de ocorrência das enxurradas, colocando em risco o rio próximo e o lençol freático.

- fato dos resíduos não serem cobertos, possibilita que materiais poluentes e contaminantes fiquem expostos e sujeitos ao acesso de catadores, animais domésticos e das águas superficiais. (Fotografia 5).

Observa-se ainda no local, forte odor de remédios e de produtos de uso hospitalar, e a presença de moscas. 


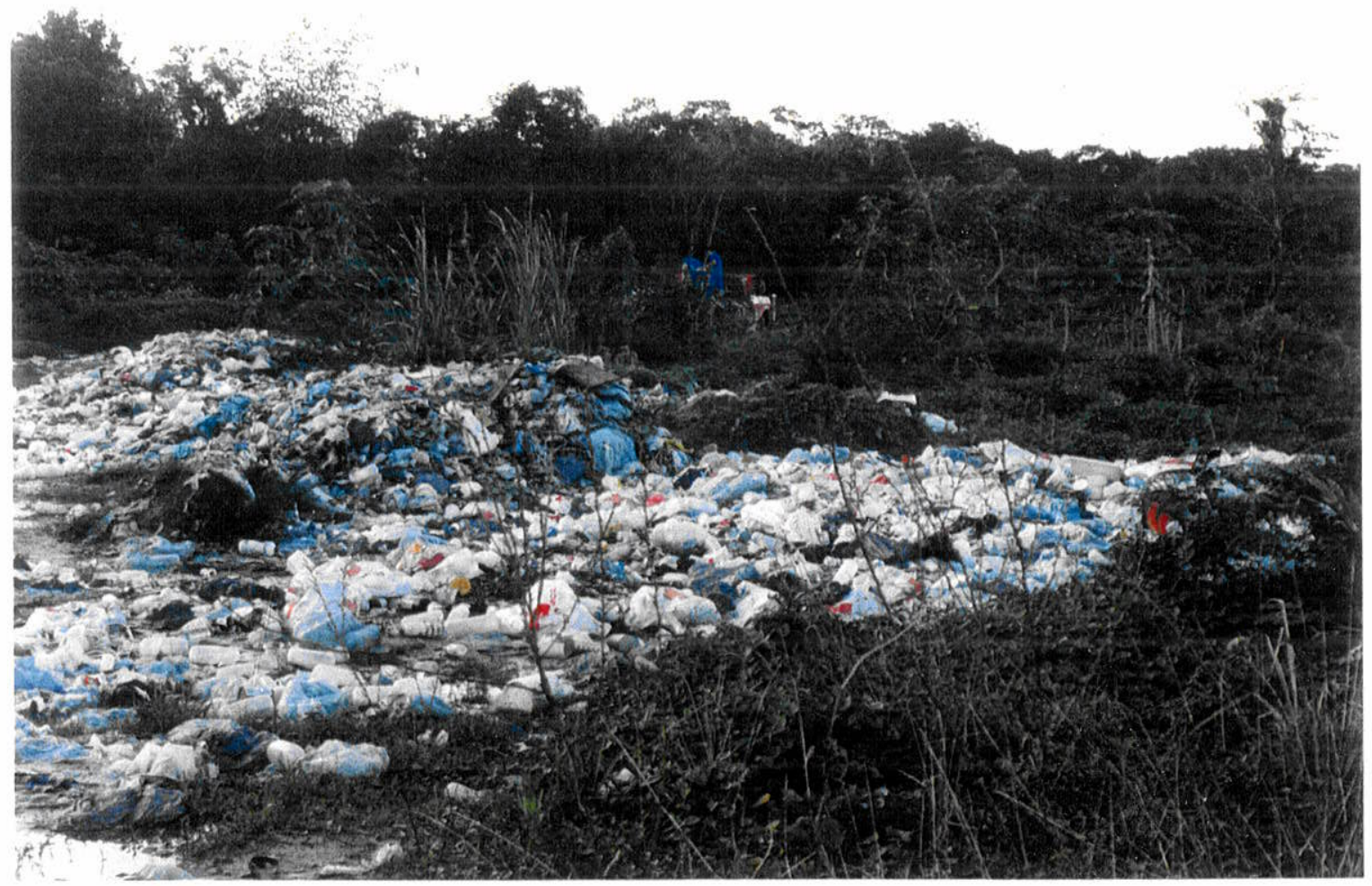

FOTOGRAFIA 4 - Flagrante de descarrregamento do lixo hospitalar no depósito de lixo de Alexandra-Matinhos. 


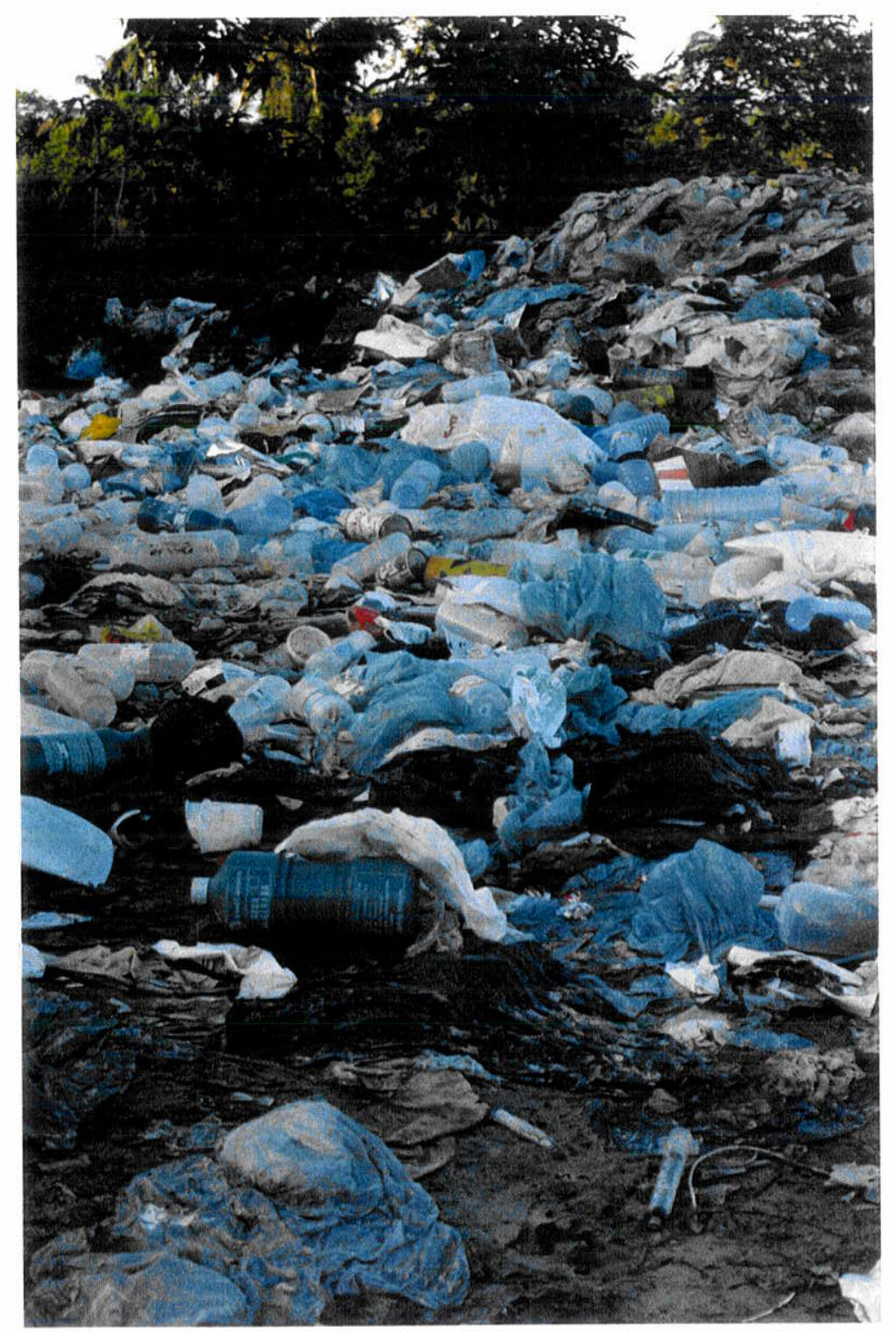

FOTOGRAFIA 5

- Foto mostrando seringas descartáveis,

agulhas e outros materiais usados em hospitais, que causam risco de contaminação no depósito de lixo de Alexandra-Matinhos. 
5.1.2.3. O Depósito de Lixo de Embocuí

- Localização

Percorrendo-se aproximadamente $2,3 \mathrm{~km}$ pela estrada de acesso ao porto de Paranaguá, a partir da BR-277, toma-se a esquerda por uma estrada não pavimentada percorre-se aproximadamente $0,5 \mathrm{~km}$ e chega-se ao depósito de lixo do Embocuí. (Figura 10).

- trecho da estrada secundária apresenta-se transitável, mesmo com chuva e tráfego de caminhões pesados.

No local ocorre vegetação arbustiva de pequeno a médio porte e, macega agreste em parte coberta pelos resíduos sólidos depositados.

Nos arredores e sobre o depósito de lixo, existem habitações, configurando um loteamento (Fotografia 6).

- Geologia

Nesse local afloram sedimentos arenosos de origem marinha, e nas proximidades ocorrem manguezais que apresentam idades holocênicas.

- Geomorfologia

Situa-se este depósito, em local de topografia plana, declividade baixa de amplitude horizontal relativamente grande.

As altitudes locais não ultrapassam 9,0 metros e, a região é suficientemente plana para possibilitar grande acúmulo de água superficial.

- Hidrogeologia

No local ocorre exposição do lençol freático, aparecendo extensas porções do depósito coberto por água.

Esse fato, somado as características arenosas do solo, possibilita infiltração de chorume que ocorre junto com $\circ$ lixo depositado.

Como o lençol freático é pouco profundo e a infiltração é facilitada pelo solo, a poluição do mesmo é quase certa. 


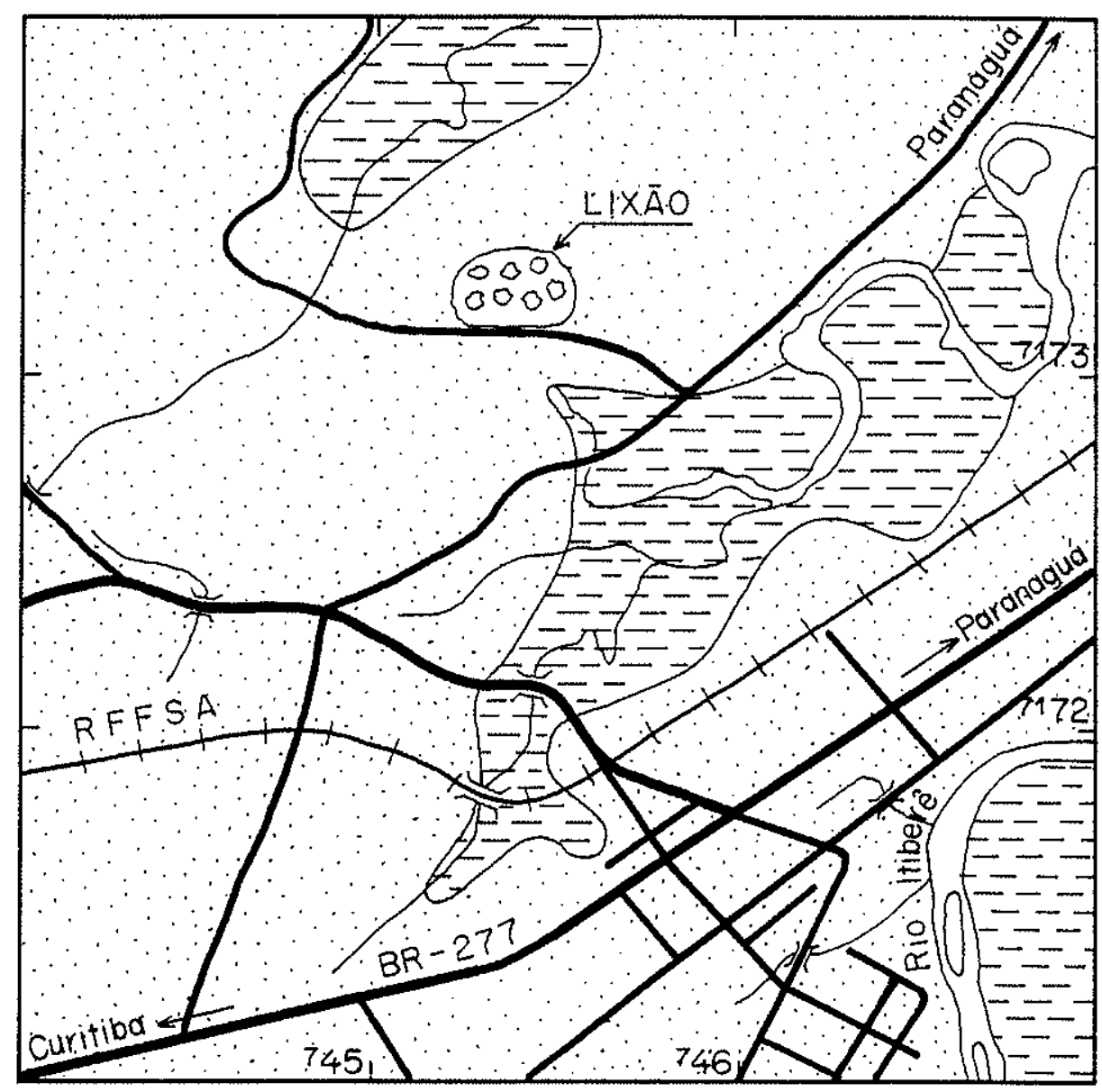

$=E-1$ Mangue.

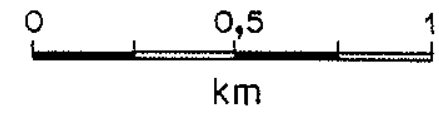

Sedimento arenoso.

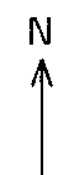

Fonte: Folha topográfica de Paranaguá (SG-22-X-D-V-2).

FIGURA 10 - Mapa mostrando a localização do depósito de resíduos sólidos do Embocuí. 


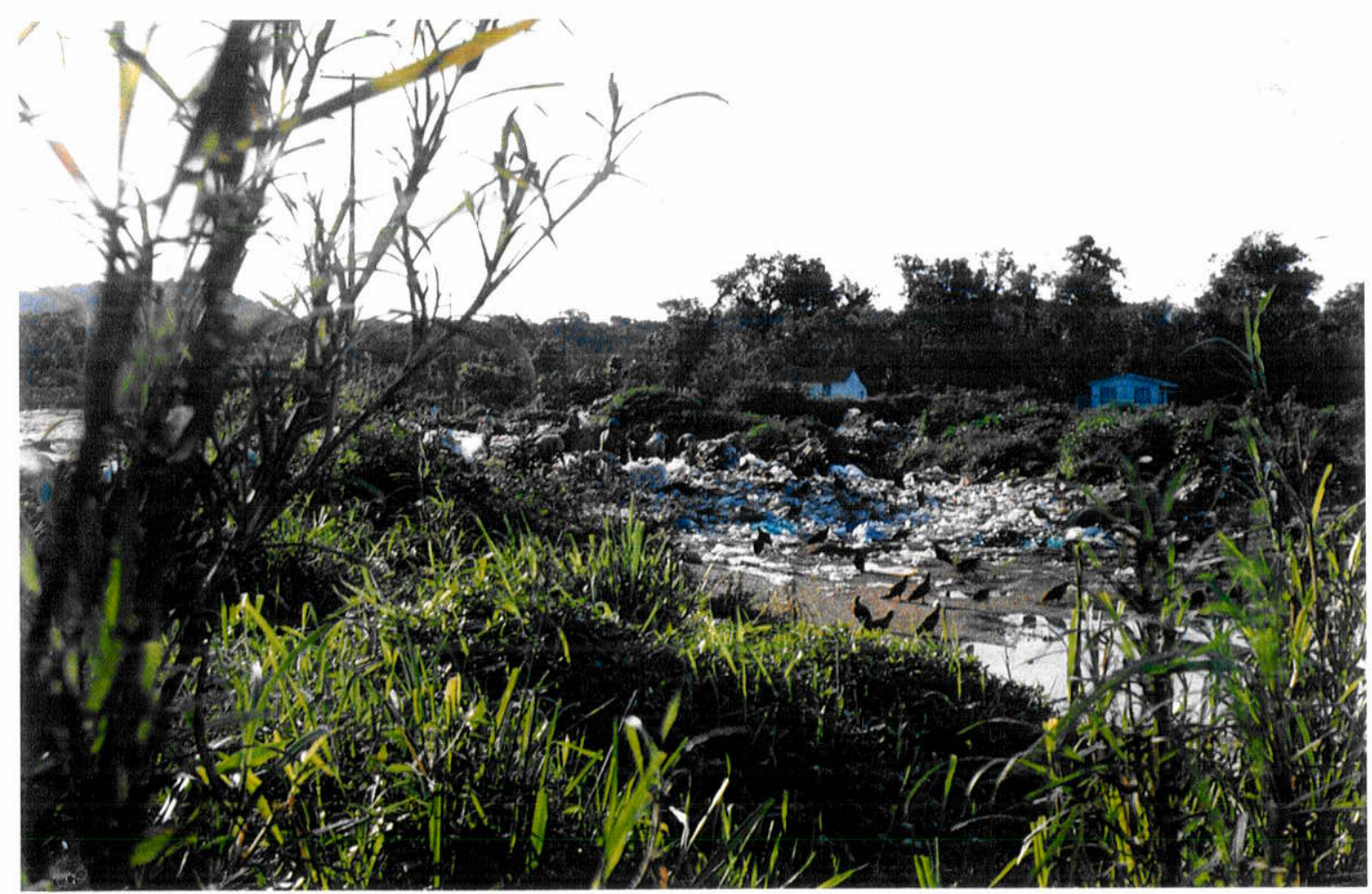

FOTOGRAFIA 6 - Loteamento situado nos arredores e em cima do depósito de lixo de Embocuí. 
- Hidrografia

- local onde se encontra o depósito pertence a bacia do rio Embocui, que percorre extensa região de mangue antes de atingir a baía de Paranaguá.

A qualidade das águas do rio Embocuí, considerado de classe II pela Portaria no 05/89 da SUREHMA, é comprometida pela localização desse depósito.

- Pluviosidade

A infiltração e disseminação de elementos poluentes, em épocas de elevados índices pluviométricos, é potencializada pelas características do solo.

Devido a grande amplitude de períodos chuvosos e aos indices pluviométricos elevados, estimamse que os indices de infiltração e disseminação de materiais poluentes sejam elevados.

- Método de operação

Não são realizadas operações de recobrimento do 1 ixo, nem qualquer outro trabalho para minimizar os impactos ambientais do depósito.

- Estimativa de Vida útil

A fisiografia do local do depósito de lixo do Embocuí, permite estimar uma vida útil média a longa.

Porém, deve-se considerar a inadequação do local para a implantação de um depósito de resíduos sólidos, com respeito ao tipo de solo, profundidade do lençol freático e não existência de materiais para cobertura do lixo.

- Impacto Ambiental e sanitário

Nota-se o escorrimento e acúmulo de chorume nas laterais do depósito de lixo, proveniente das atividades de decomposição da matéria orgânica do Iixo. (Fotografia 7).

A prática de não enterrar o lixo disposto, de maneira sistemática, propicia a ação dos catadores e aves carnívoras como urubus. (Fotografia 8 ). 


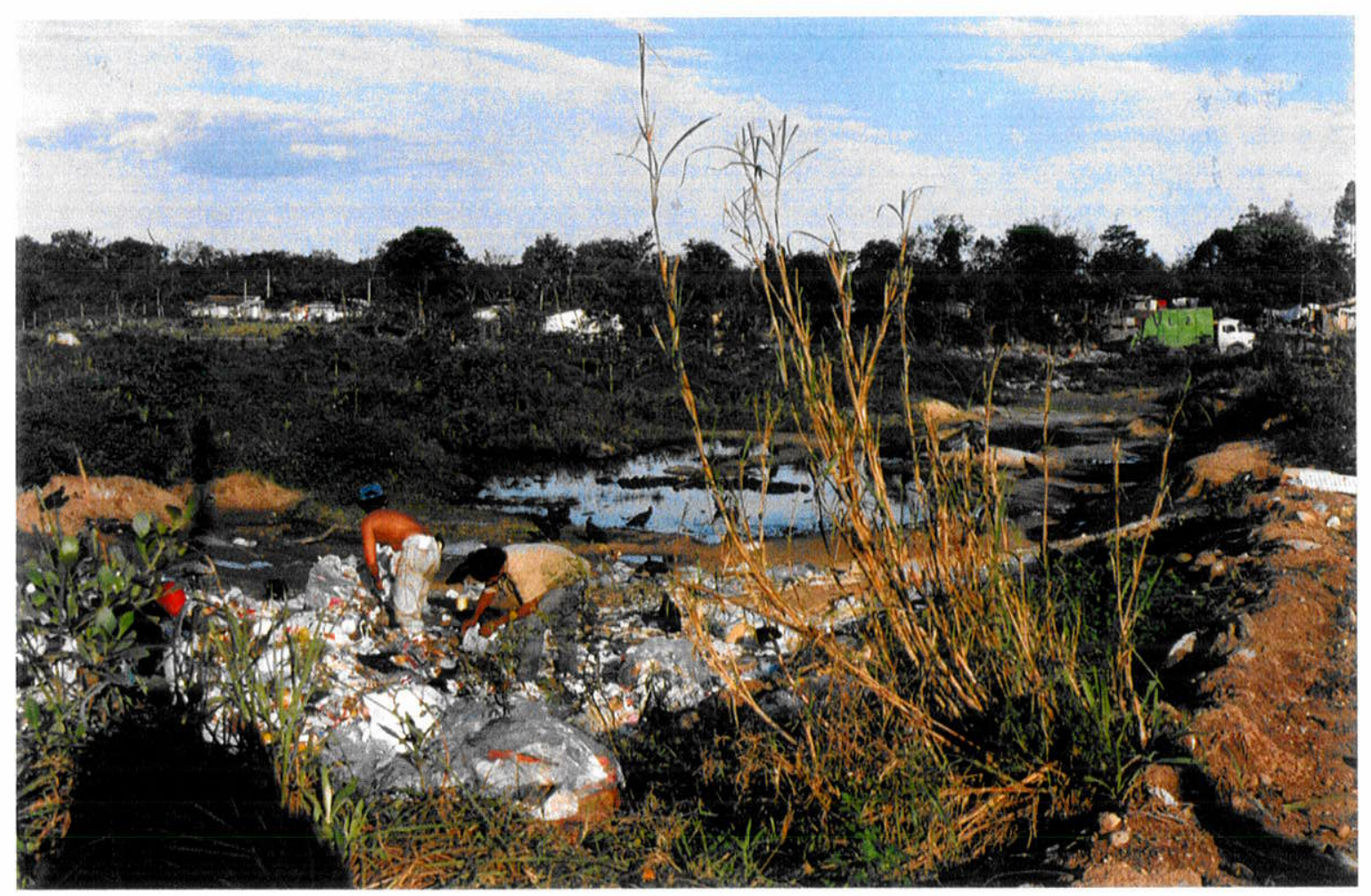

FOTOGRAFIA 7 - Exposição do chorume proveniente da parte mais antiga do depósito de lixo de Embocuí. 


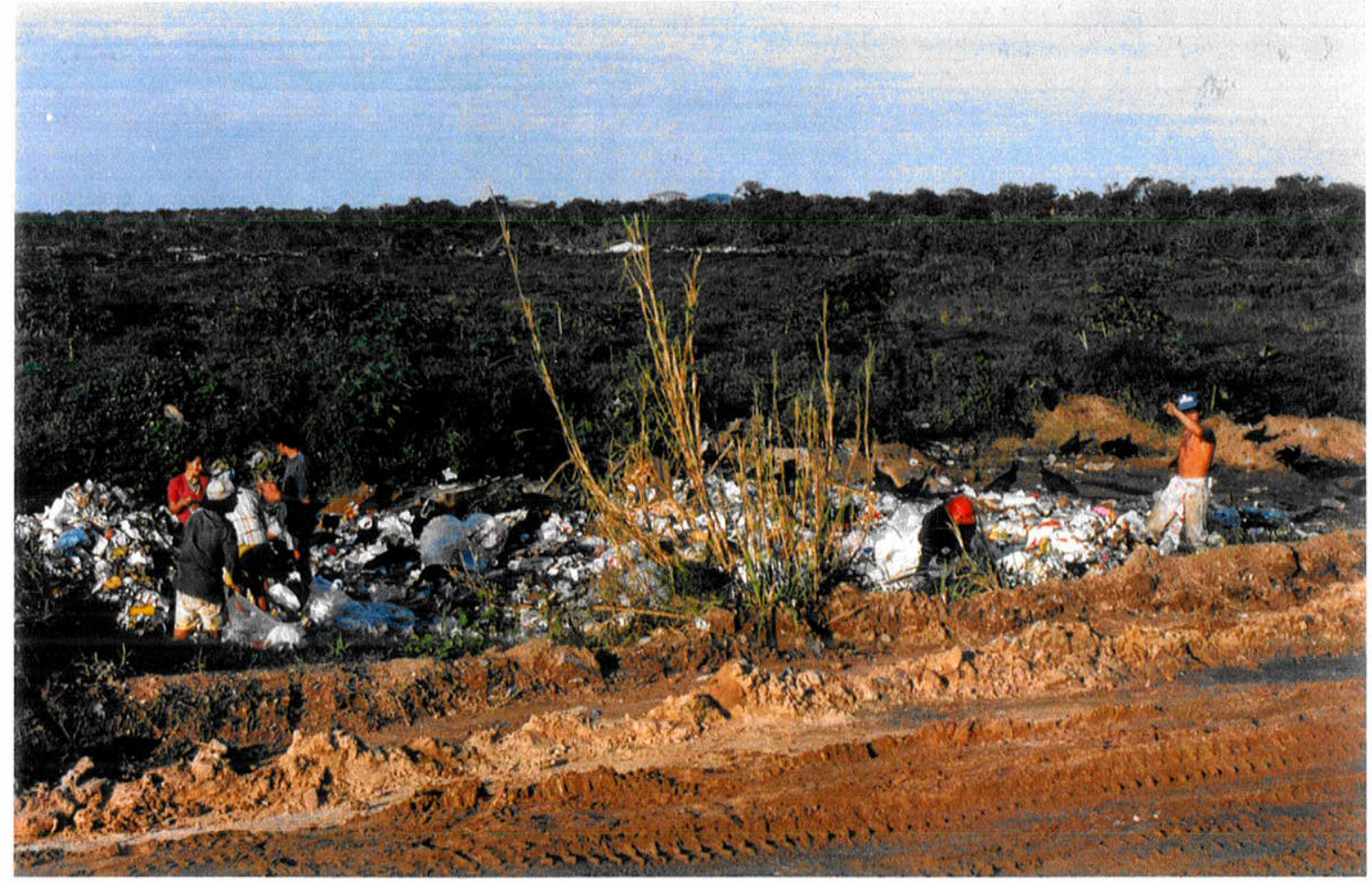

FOTOGRAFIA 8 - Ação dos catadores e dos urubus no depósito de lixo de Embocuí. 
A poluição do lençol freático fica evidenciada pelo fato deste ser aflorante e, pelas caracteristicas de cor e odor dessa água no local.

Essas características proporcionam substrato adequado para proliferação de vetores, principalmente moscas, que ocorrem intensamente na área e para a deteriorização do ar que apresenta intenso mau cheiro.

5.1.2.4. O Depósito de Lixo de Shangrilá

- Localização

Esse depósito situa-se em estrada secundária no Balneário de Shagrilá, distante $2,5 \mathrm{~km}$ da rodovia Praia de Leste-Pontal do Sul (PR-412). (Figura 11).

A vegatação local compõem-se de arbustos e árvores de médio e grande porte, sendo que foi efetuado desmatamento de uma pequena área para se implantar o depósito.

A estrada secundária não pavimentada, apresenta-se com trechos de difícil acesso, porém permite o tráfego dos caminhões de coleta de lixo sob qualquer condição de tempo. (Fotografia 9).

A topografia local é suave e plana, sendo as altitudes médias em torno de 5,0 metros, ocupando o depósito uma área em expansão, que situa-se distante de conjuntos urbanos, havendo contudo, algumas habitações em suas imediações.

- Geologia

- substrado no local do depósito, compõe-se de sedimentos arenosos indiferenciados de origem marinha de idade holocenica, que geram solos de textura arenosa e de alta permeabilidade.

- Geomorfologia

As declividades baixas, configuram um local praticamente plano, sem limites para a expansão do depósito, pois as altitudes não ultrapassam 5,0 metros.

Nas proximidades existem pequenos cursos de água como o rio Perequê, que situa-se a aproximadamente $500 \mathrm{~m}$ do depósito de 1ixo.

- Hidrogeologia

- lençol freático é exposto em alguns locais e o solo é caracteristicamente arenoso, isto possibilita alta permeabilidade. (Eotografia 10). 


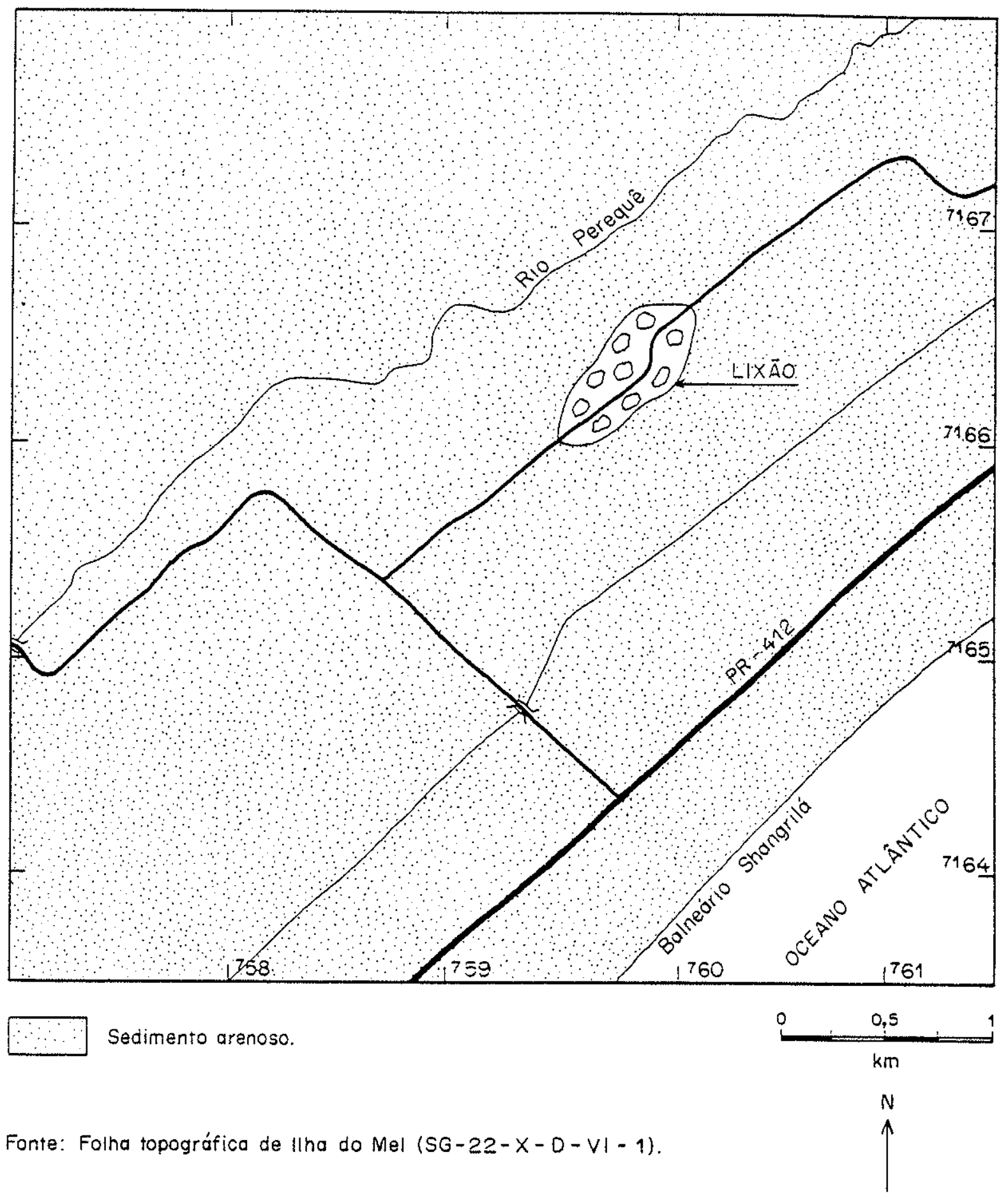

FIGURA 11 - Mapa de localização do depósito de lixo de Shangrilá 


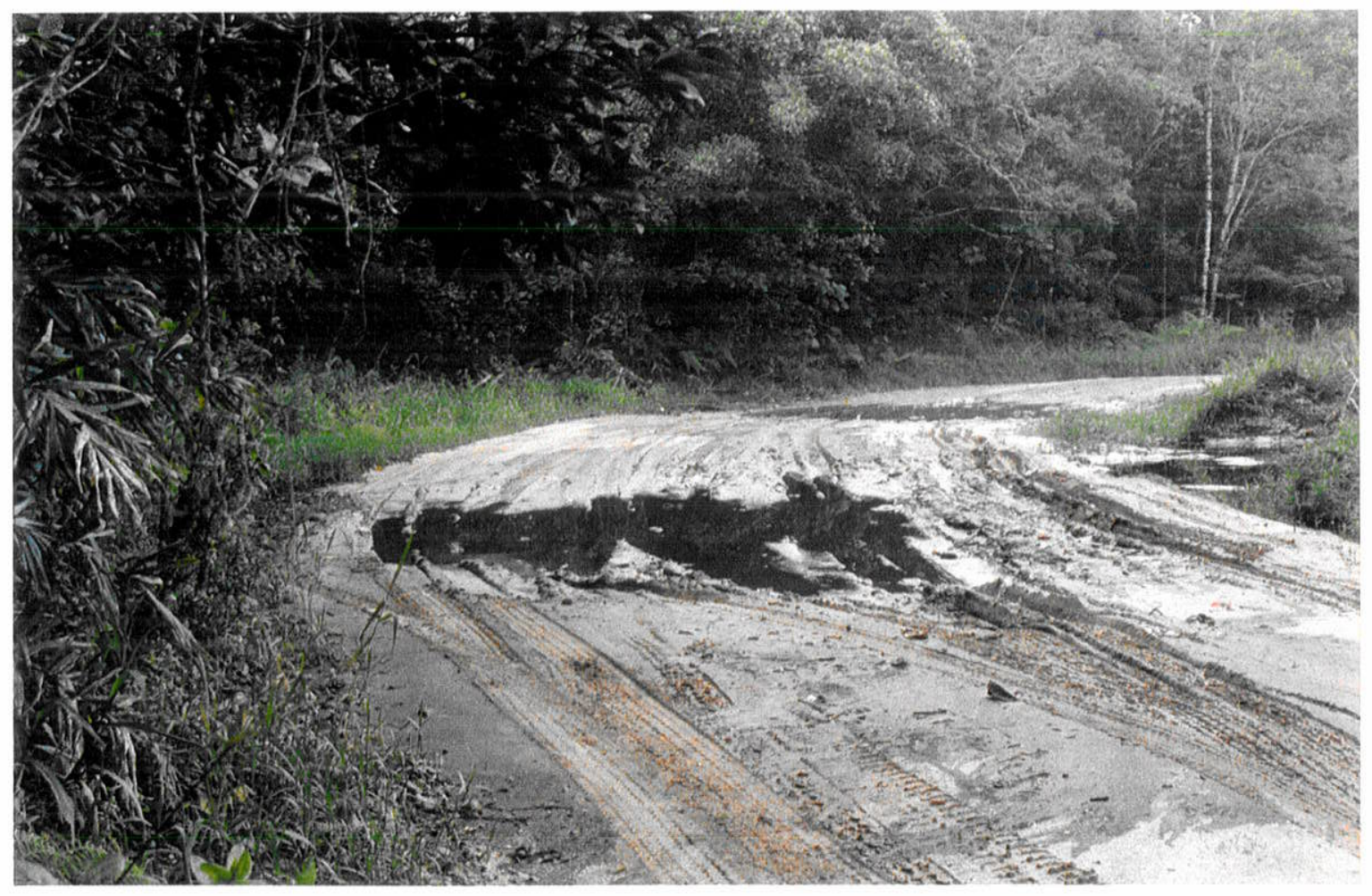

\author{
FOTOGRAFIA 9 - Trecho de difícil tráfego na estrada secundária de \\ acesso ao depósito de lixo de Shangrilá.
}




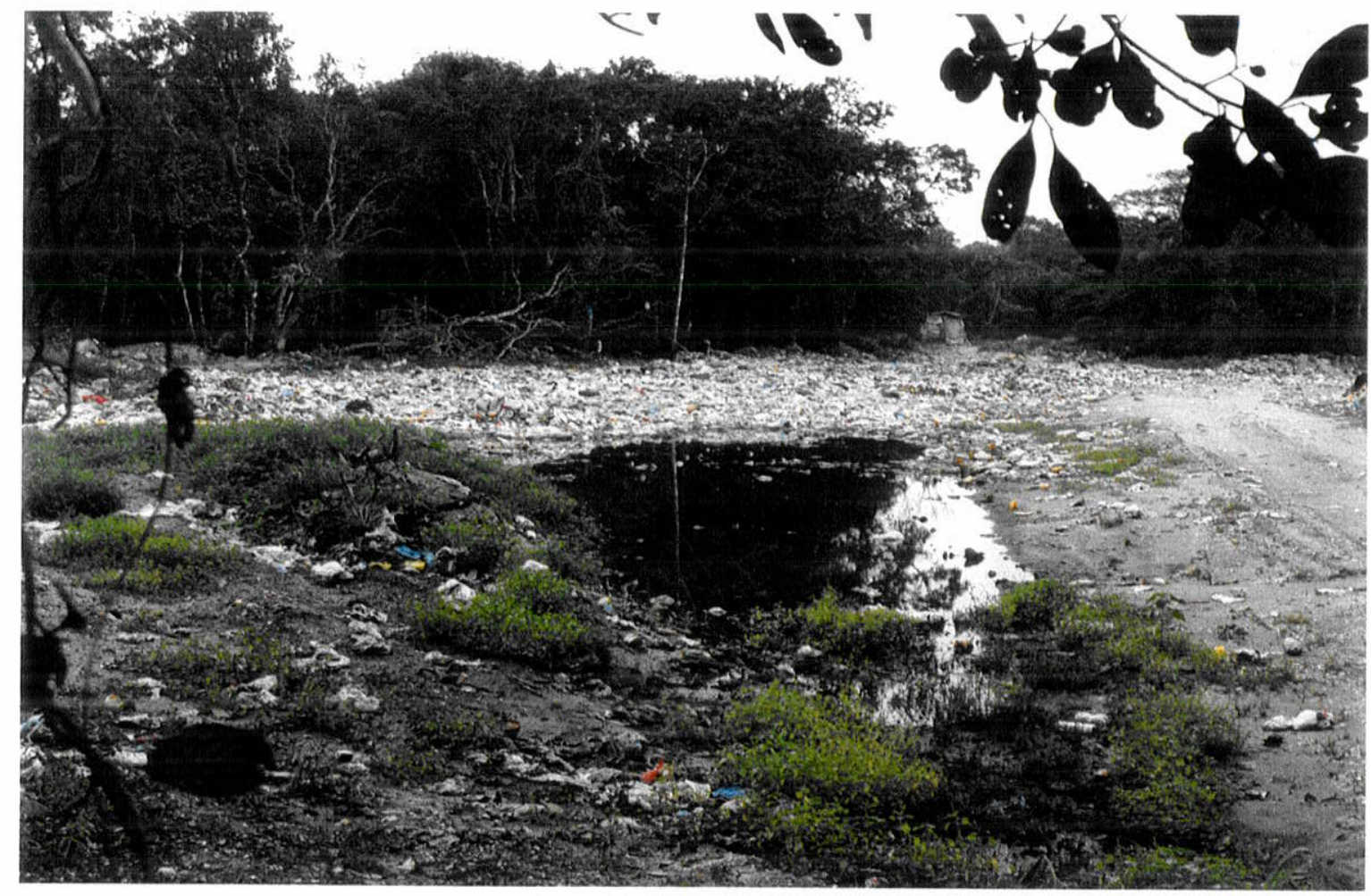

FOTOGRAFIA 10 - Exposição do lençol freático no depósito de lixo de Shangrilá. 
- Hidrografia

Nas proximidades do depósito, ocorrem vários cursos de água de pequeno porte. O mais importante, por atravessar grande extensão do Balneário de Pontal do sul e formar uma pequena região de mangue, é o rio Penedo.

Esse rio, considerado de Classe II pela Portaria $n^{\circ}$ 05/89 da SUREHMA, apresenta a qualidade de suas águas comprometidas pela expansão do depósito de Iixo, tendo em vista a alta permeabilidade dos areais.

- Pluviosidade

Os maiores índices pluviométricos, no litoral, ocorrem no verão, com máximas de até $400 \mathrm{~mm}$ em 24 horas.

Essa característica tende a uma acentuação das propriedades poluentes desse depósito, tendo em vista o maior acúmulo de lixo pelo aumento populacional nas épocas de veraneio.

Estima-se portanto, que nessas ocasiões ocorra não somente maiores infiltrações, mas também maiores indices de carreamento superficial de elementos poluentes, que certamente atingem os cursos de água próximos.

- Método de Operação

Esse depósito recebe $\bigcirc$ lixo de todos os Balneários do município de paranaguá e, os resíduos sólidos recolhidos na Ilha do Mel. Os resíduos provindos da Ilha do Mel, são transportados por barco até Pontal do sul e, posteriormente levados por caminhão até o depósito de Shangrilá.

A operacionalização no depósito consiste em uma compactação do lixo por um trator de esteira e, sua cobertura parcial por terra do próprio local. Essa terra é proveniente de escavações, feitas pelo próprio trator de esteira, na área do depósito, não apresentando características adequadas para esse uso.

- Estimativa de Vida útil

A vida útil desse depósito, considerando que a área apresenta topografia suave, sem contornos limitantes, pode ser estimada como de longa duração.

Porém, a falta de material adequado para cobertura do lixo, no local, o lençol freático exposto, o solo arenoso de alta 
permeabilidade e a existência de inúmeros cursos de água na região, são fatores que desaconselham sua situação nessa área.

- Impacto Ambiental e Sanitário

A prática totalmente aleatória de cobrir porções do lixo depositado, permite que a maior parte do mesmo fique sujeito a ação dos catadores, águas pluviais e animais. (Fotografia 11).

A caracteristica do lençol freático ser exposto, possibilita contato direto do lixo com as águas que se infiltram no solo, bem como, permite que elementos poluentes sejam levados para os cursos de águas locais.

Há proliferação de vetores, notadamente de moscas, que ocorrem em grande número na área do depósito e em suas imediações. Verifica-se, também, intenso mau cheiro proveniente da decomposição do Iixo.

Apesar do depósito situar-se distante dos núcleos habitacionais, observa-se a presença de moradias de catadores nas suas proximidades.

Com relação a medidas mitigadoras dos impactos ambientais além da cobertura não sistemática e incompleta do lixo, estas não existem. 


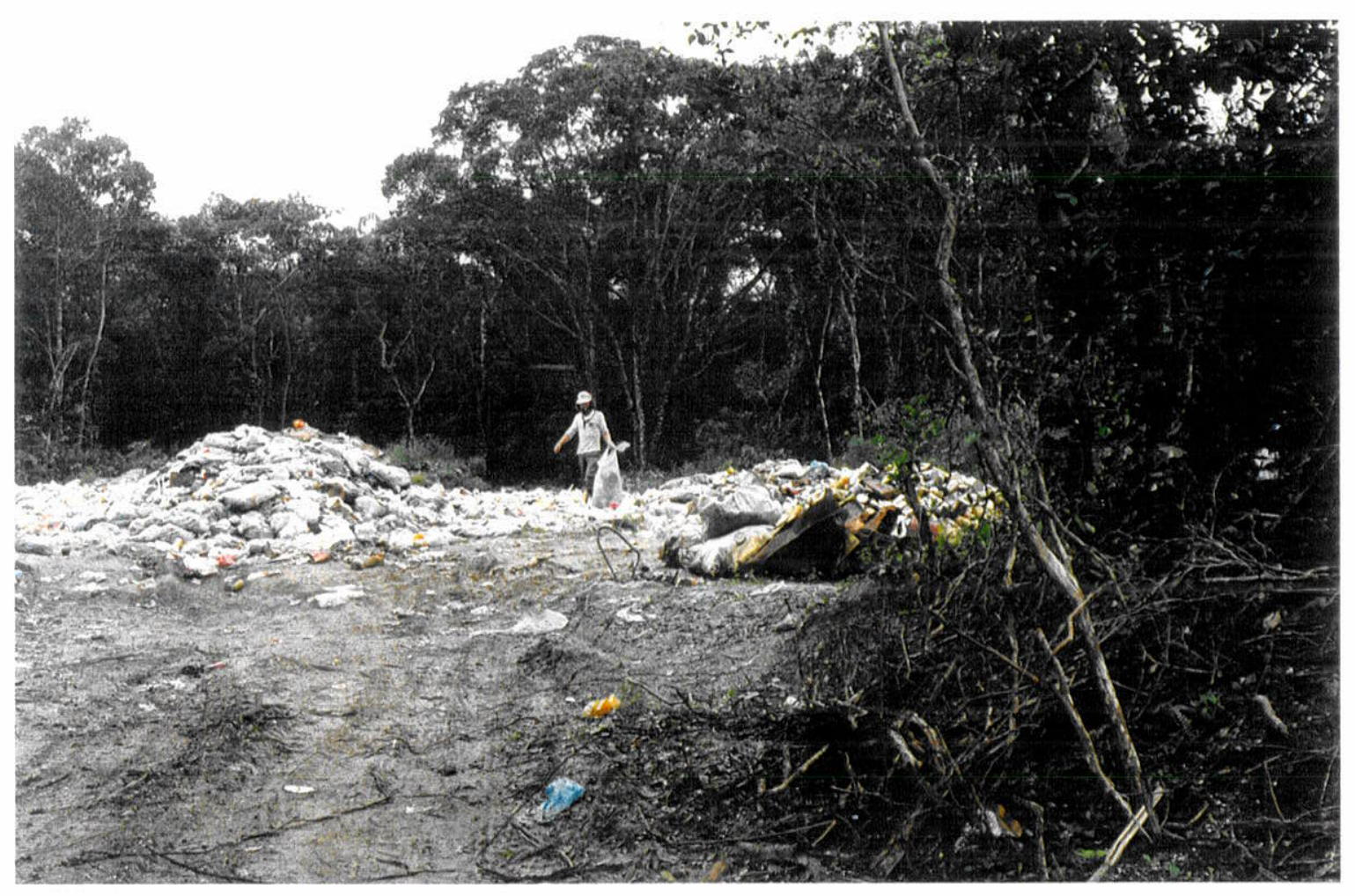

FOTOGRAFIA 11 - Foto mostrando um catador fazendo reciclagem do lixo, separando papelão, latas e vidros no depósito de lixo de Shangrilá. 
5.2. Avaliação da Área em Estudo para a Locação de Aterros Sanitários

Esta avaliação foi efetuada tendo em vista a localização de aterros sanitários para receber resíduos sólidos urbanos e alguns resíduos industriais não perigosos, ou seja, resíduos da classe II e Classe III.

\subsubsection{Geologia}

Durante o mapeamento geológico, foram evidenciadas na área, as seguintes unidades litoestratigráficas:

a) Formação Rio das Cobras de idade arqueana, constituída principalmente por Xistos;

b) Complexo gnáissico migmatítico costeiro do Proterozóico inferior, composto por granitos, migmatitos e gnáisses;

c) Formação serra Geral de idade jurássica-cretácea, constituida por diques de diabásio;

d) Formação Alexandra do Terciário, formada por conglomerados, arcóseos e sedimentos areno-argilosos;

e) Sedimentos do Holoceno constituídos por depósitos de cascalhos, depósitos arenosos, depósitos areno-sílticoargilosos, colúvios, aluviões e mangues.

Essas unidades litoestratigráficas e as principais estruturas geológicas que cortam as suas litologias estão representadas no Anexo 1.

A Formação Rio das Cobras aflora na extremidade leste da área. Esta formação segundo IIMA e LOPES (1985), é constituída por litologias arqueanas de baixo grau metamórfico, tais como: biotita quartzo-xistos, moscovita-quartzo-xistos, biotititos, clorita-xistos, clorita-quartzo-xistos, quartzitos, calco-xistos e xistos granatíferos.

Os xistos desta formação, nos afloramentos visitados apresentam-se alterados, sendo possível no entanto a visualização da extrutura xistosa e a presença de grande quantidade de muscovitas, cloritas e biotitas. Esses minerais alterados produziram, nesses locais, solos argilosos com espessura de 1,5 metros. 
- Complexo gnáissico migmatítico costeiro, definido pela Minerais do Paraná S.A. - MINEROPAR (1989), engloba migmatitos, granitos gnáissicos e de anatexia.

Esse Complexo aflora em uma faixa alongada no sentido $\mathrm{N}-\mathrm{S}$ na porção oeste da área. (Anexo 1). A extremidade leste desta faixa configura $\circ$ limite entre as porções mais baixas, onde afloram os sedimentos do cenozóico e as posições elevadas da área, locais ocupados pelas rochas do Pré-Cambriano.

Ao longo desta extremidade leste afloram granitos, que também ocorrem nas porções mais baixas, em meio aos sedimentos, formando elevações. Esses granitos configuram na região algumas pedreiras, em atividade, das quais o granito é extraído e transformado em paralelepipedos para calçamento. (Anexo 1).

No caminhamento efetuado na área, para executar o proposto na metodologia deste trabalho, determinou-se a composição mineralogica desses granitos como: plagioclásios, mega-cristais de microclínio, quartzo, biotita e hornblenda. Em alguns foram observadas grandes quantidades de epídoto.

Quanto a cor, predominam os leucocráticos, embora ocorram alguns granitos mesocráticos ricos em biotita, anfibólios e epídoto.

$\mathrm{Na}$ porção mais central da faixa de exposição do Complexo gnáissico migmatítico costeiro na área, afloram granitos gnáissicos cuja mineralogia macroscopicamente é semelhante a dos granitos. o bandamento dessas rochas é bem evidenciado, principalmente pelos fenocristais de feldspatos.

os contatos entre o granito e os gnaisses na maioria das vezes é encoberto, ou apresenta-se gradual, contudo observou-se a existência de diáclases e falhas próximas aos contatos, bem como, a presença mais evidenciada de epídotos no granito.

Recentemente, BASEI et al. (1992) dataram esses granitos determinando suas idades entre 450-614 milhões de anos, contudo não propuseram uma estratigrafia para a região.

Com relação aos materiais de alteração dessas rochas, devido a pouca variação minerológica entre elas, são muito similares. Em toda área de ocorrência do complexo gnáissico migmatítico costeiro, na região estudada, os solos são característicamente argilosos, em 
razão principalmente da alteração dos feldspatos presentes nessas rochas.

A espessura dos solos, medida nos cortes das pedreiras e ao longo de barrancos de margem de rios, varia entre 0,30 - 3,0 metros, estando as mesmas espessuras nas porções mais elevadas do terreno.

- contato entre o Complexo gnássico migmatítico costeiro e a Formação Rio das Cobras é feito por falha com direção $\mathrm{N}-\mathrm{S}$ em alguns locais, estando encoberto em outros.

$\mathrm{Na}$ ilha do Mel e na ilha da Cotinga ocorrem altos topográficos com exposições do Complexo gnáissico migmatítico costeiro.

Os diques de diabásio da Eormação Serra Geral afloram em meio as rochas pré-cambrianas (Anexo 1). Esses diques com orientação $\mathrm{N}$-W são constituídos por feldspatos plagioclásios e piroxênios, possuem textura fina e são melanocráticos.

Quando alterados produzem material argiloso de cor vermelha, devido ao excesso de piroxenios. Isto produz um incremento na quantidade de argilas nos solos situados em suas imediações.

Os materiais de alteração dessas rochas apresentam espessuras semelhantes aos granitos, variando de 0,20 - 3,0 metros. Essas espessuras foram medidas em cortes ao longo da rodovia Alexandra-Matinhos a PR-508, que corta alguns diques quase que perpendicularmente às suas direções $\mathrm{N}-\mathrm{W}$.

A Eormação Alexandra, reestudada por LIMA e ANGULO (1990), em função de um conteúdo palinológico foi datada como terciária, e sua composição litológica considerada restrita a arcóseos, areias arcoseanas, lamas, conglomerados polimitícos e depósitos orgânicos. BIGARELLA et al. (1978), citam o resultado de perfurações submarinas realizadas pela Solotécnica na região do Porto de Paranaguá. Dessas sondagens uma atravessou os sedimentos da Formação Alexandra a aproximadamente 20,0 metros de profundidade. As camadas penetradas da Formação Alexandra, eram constituídas por siltitos e argilitos arenosos contendo cascalho intercalado.

Na Praia de Leste, situada na porção sudeste da área em estudo, esses mesmos autores relataram $\circ$ encontro de camadas argilosas e arenáceas da Formação Alexandra à profundidade de 45,0 metros, em um poço perfurado para água subterrânea. 
Sobrepostos aos sedimentos da Eormação Alexandra, em ambos os casos, foram encontrados depósitos de cascalhos cobertos por depósitos arenosos marinhos.

Os afloramentos desta formação ocorrem esparços na posição nordeste e oeste da área (Anexo 1). A seção tipo estudada por ANGULo (1990) situada nas proximidades do encontro das estradas CuritibaParanaguá (BR-277) e Alexandra-Matinhos (PR-508).

Neste local, afloram areias arcoseanas sobrepostas por uma mistura de lamas e lamas arenosas e uma pequena camada linhitica na base.

Nos outros locais de afloramentos foram observadas espessas camadas de lamas, com diâmetros de até 2,0 metros, relacionados com a parte superior da formação.

Os solos residuais desta formação, são preponderantemente argilosos, com espessuras médias de 2,0 metros que foram medidas em barrancos das colinas configuradas pelas rochas da Formação Alexandra.

Os cascalhos afloram na porção noroeste da área nas proximidades da Formação Alexandra e dos granitos do complexo gnássico migmatítico costeiro. (Anexo 1).

Esses sedimentos são relacionados por BIGARELIA et al. (1978), como produto das mudanças climáticas ocorridas no Pleistoceno, que possibilitaram erosão de depósitos correlativos.

$\mathrm{Na} a ́ r e a$ de afloramento os cascalhos apresentam predominantemente seixos de quartzo, os quais são pouco arredondados e encontram-se em meio a uma matriz de areia e argila.

os solos nesses locais possuem espessuras de até 1,50 metros e apresentam-se areno-argilosos com pedregulhos.

os sedimentos arenosos de origem marinha, distribuem-se ocupando a maior extensão da área, em sua porção continental e nas ilhas. (Anexo 1).

Esses sedimentos arenosos foram interpretados por ANGULO (1990), como formadores de cordões litorâneos gerados pelas variações do nivel do mar ocorridos no Quaternário. Esses cordões, segundo o mesmo autor, foram remobilizados no Holoceno por ventos, produzindo dunas. 
Em toda sua área de afloramento esses depósitos apresentaram-se de constituição arenosa fina, não sendo observadas variações nessa granulometria até profundidades de 1,50 metros.

BIGARELIA et al. (1978), relatam as profundidades desses depósitos, obtidas através de perfuração de poços, variando entre 4,0 - 25,0 metros na região litorânea.

Através de sondagens elétricas efetuadas sobre esses sedimentos, com a finalidade em caracterizar as cotas do lençol freático, foram observadas profundidades do nível d'água variando entre $5,0-9,0$ metros.

os materiais residuais desses sedimentos praticamente se confundem com os mesmos, havendo uma distribuição granulométrica homogênea ao longo dos perfis levantados, produzindo solos areno siltosos.

Os depósitos areno-siltico-argilosos foram relacionados por BIGARELLA et al. (1978), à dinâmica das águas durante a subida do mar no Quaternário, retrabalhando antigos depósitos.

Afloram na porção noroeste, no extreno sul da área e margeando os mangues. (Anexo 1).

Com relação a sua constituição granulométrica, apresentam-se homogeneos, gerando solos areno argilosos com espessuras superiores a 1,50 metros.

Os colúvios no litoral paranaense foram descritos por vários autores, entre eles ANGULO (1990), que descreve os colúvios como uma série de sedimentos associados a vertentes, nos quais não se observam evidencias de transporte por fluxos de baixa viscosidade.

Na área estudada, os colúvios estão associados às vertentes das elevações das rochas que configuram o Complexo gnáissico migmatítico costeiro. (Anexo 1).

Esses depósitos de colúvio, são predominantemente finos com proporções pequenas de areia, configurando quase um sedimento terrígeno. Essas características se repetem em todos os afloramentos, fato que nos leva a supor serem esses colúvios gerados por movimentos de massas lentos.

Os solos nesses locais são argilosos e alcançam profundidades de até 1,5 metros. 
Os aluviões idiferenciados englobam os depósitos fluviais antigos ou modernos, não havendo separação entre os tipos e morfologia dos depósitos. Na área mapeada ocorrem sedimentos argilosos e argilo-arenosos, sendo os primeiros preponderantes.

A diversificação granulométrica dos depósitos fluviais no litoral é citada por ANGULO (1990), que relaciona as principais granulometrias desses depósitos como areias, areias argilosas, argilas arenosas, siltes arenosos e siltes argilosos.

Área de exposição dos aluviões na região estudada abrange uma extensa faixa margeando as rochas do Pré-Cambriano e, uma ampla porção das regiões mais baixas margeando os principais rios. (Anexo 1).

Os solos dessas áreas são argilosos e atingem profundidades médias de 2,0 metros.

Os mangues são áreas sujeitas aos fluxos e refluxos da maré (IPARDES, 1989).

Essas áreas apresentam-se constituídas no local estudado, predominantemente, por solos siltosos de cor preta, ricos em matéria orgânica, com expessuras superiores a 1,20 metros.

Com relação as estruturas geológicas, foi observado a sua maior ocorrência nas rochas pré-cambrianas. (Anexo 1). Nos sedimentos, essas estruturas ocorrem próximas ao Complexo gnáissico migmatítico costeiro, desaparecendo quase que por completo nos locais mais afastados deste. (Anexo 1).

Essas estruturas, representadas por diáclases e falhas, foram geradas segundo BASEI et al. (1992), por processos de sucessivas subducções seguidas de colisões com sentido predominante de acresção de terrenos de leste para oeste.

Nas figuras 12 e 13 estão representadas em diagrama SCHIMIDT LAMBERT as atitudes das diáclases e falhas medidas na região em estudo. 


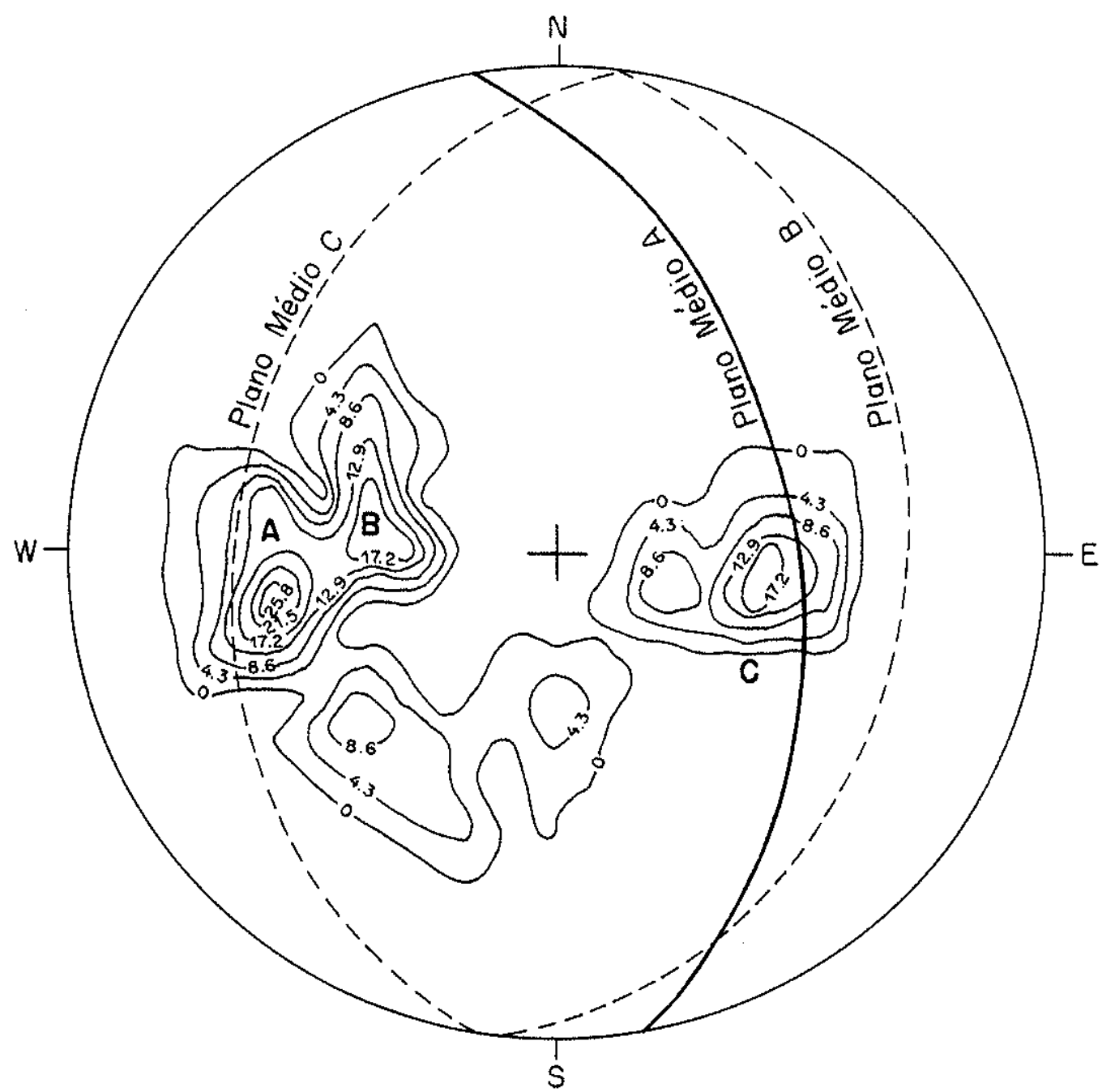

FIGURA 12 - Diagrama SCHIMIDT LAMBERT com representação polar de diáclases.

Total de medidas - 233.

Isocurvas de 4,37, 8,67, 12,98 e 17,28 dos dados.

Plano médio principal (A): N10W/50NE (25,8 dos dados)

Planos médios secundários:

$B:$ NO6E/3OSE (17,2\% dos dados)

C: NO9E/34SW (17,2: dos dados) 


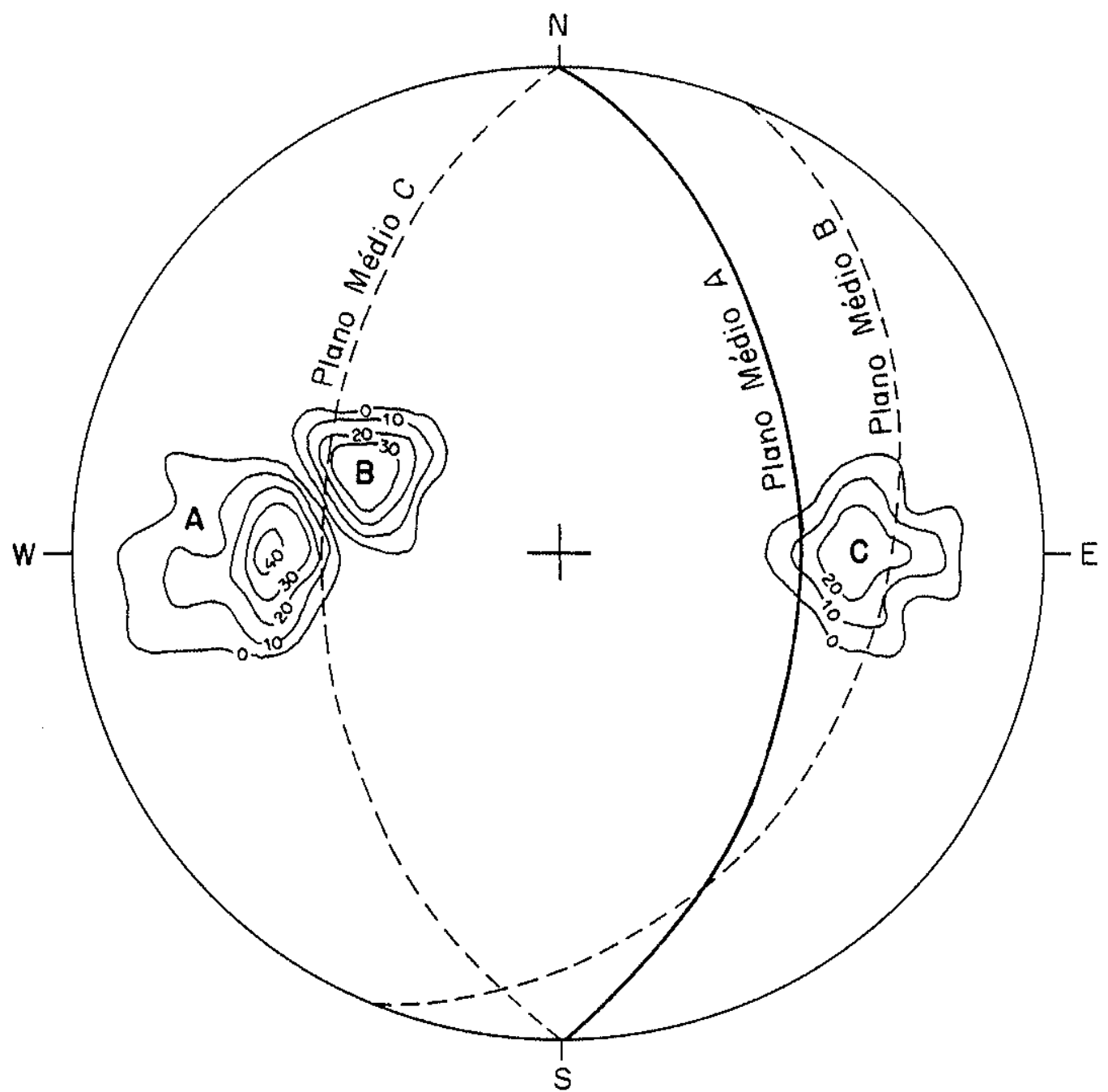

FIGURA 13 - Diagrama SCHIMIDT LAMBERT com representação polar de falhas.

Total de medidas - 100 .

Isocurvas de 08, 10\%, 208, 308 e 408 dos dados.

Plano médio principal (A): NS/5OE (40\% dos dados)

Planos médios secundários:

$B: N 22 E / 35 S E$ (308 dos dados)

C: NS/50W (20\% dos dados) 
Foi observado que na área dos sedimentos a grande maioria das fraturas estão preenchidas, geralmente por material argiloarenoso. As fraturas situadas nas rochas pré-cambrianas em sua grande maioria são abertas, e as que se encontram colmatadas são preenchidas por cloritas e biotitas.

As diáclases apresentam um plano principal com atitudes de N10W/5ONE, e dois planos secundários com atitudes de NO6E/30sE e N09E/34SW. (Eigura 12)

As falhas possuem um plano principal com atitudes NS/50E, e dois planos secundários com atitudes de N22E/35SE e NS/50W. (Figura 13)

Isto significa que a água que se infiltra nessas diáclases e falhas dirige-se preferencialmente para leste, em direção a planície litorânea. Portanto, essas estruturas são importantes como alimentadoras do aquífero subterrâneo, devendo os locais onde ocorrem serem preservados de impactos ambientais.

Assim o contexto geológico oferece restrições a locação de aterros sanitários sobre as rochas pré-cambrianas, nos locais onde ocorram essas estruturas. Pois, elas poderiam se transformar em condutos de poluentes para o lençol subterrâneo, como foi observado por ELLERT e ROSA FILHO (1988).

Com relação aos materiais de alteração, as restrições se fazem à composição dos solos dos sedimentos arenosos de origem marinha, e dos cascalhos que podem apresentar pouca argila e serem permeáveis, características que segundo a CETESB (1985) são indesejáveis para a instalação de qualquer tipo de aterro sanitário.

As áreas de mangue são inadequadas para a locação de aterros sanitários, pois estão sujeitas a inundações. Além disso, a presença de argilas orgânicas nos solos de mangue, diminuem suas resistências de suporte, fator que segundo SCHALCH et al. (1992), não é desejável para locais a serem implantados aterros sanitários.

\subsubsection{Geomorfologia}

A interpretação de fotografias aéreas em escala de 1:25.000, as observações exploratórias no campo, o conhecimento anterior da área, e referências relativas a geomorfologia e geologia regional, 
possibilitaram a identificação das unidades geomórficas componentes da área estudada.

Dois domínios geomórficos englobam a área em apreço, a região montanhosa litorânea e a região da planície litorânea. (Anexo 2).

A região montanhosa litorânea compreende cotas entre 20 1222 metros e é constituída por granitos, granitos gnássicos e xistos. Apresenta-se irregularmente desgastada não configurando uma área plana, ocupando a região extrema oeste da área mapeada.

$\mathrm{Na}$ região montanhosa litorânea foram distinguidas sete superfícies geomórficas, a saber: pediplanos residuais de topo, pediplanos residuais dissecados, pediplanos residuais muito dissecados, piemontés e áreas indiferenciadas, pedimentos, morros altos dissecados e vales.

Os pediplanos residuais representam áreas aplainadas por intenso rebaixamento $e$, apresentam cotas altimétricas variando entre $400-1222$ metros.

As declividades predominantes são de $0 \%$ - 58 , porções com inclinações de 58 - 108 e pequenas extensões com mais de 108. (Anexo 3).

Os pediplanos residuais de topo, abrangem duas áreas dispostas com uma orientação, praticamente $\mathrm{N}-\mathrm{S}$, na porção mais elevada da região montanhosa litorânea. (Anexo 2). Essas áreas apresentam cotas altimétricas variando de 700 - 1222 metros.

os pediplanos residuais dissecados, configuram uma pequena área mais rebaixada, a sudeste dos pediplanos residuais de topo. (Anexo 2). As cotas altimétricas dessa área variam entre $600-1100$ metros.

Nesses pediplanos foram observadas áreas degradadas, indicativas de um possível reafeicoamento das superficies aplainadas. os pediplanos residuais muito dissecados, abrangem cinco área dispostas no extremo sudoeste da região montanhosa litorânea. (Anexo 2). Representam os pediplanos mais rebaixados da área, estando suas cotas altimétricas entre 400 - 600 metros.

- retrabalhamento de pediplanos, segundo BIGARELLA et al. (1965), deve-se a curtas flutuações climáticas em direção ao úmido, o 
que provocaria ligeiro abaixamento do nível de base de erosão local, nas proximidades da área fonte.

As formas topográficas desses pediplanos, são elevações alongadas, que obedecem a disposição das curvas de nível.

os piemontes e áreas indiferenciadas, são representados por áreas de transição entre os pediplanos e os pedimentos, ou entre os pedimentos. (Anexo 2).

Essas áreas nào se enquadram como pediplanos ou pedimentos e, segundo BIGARELLA et al. (1978), representam períodos intermediários entre a formação dos pedimentos. Nesses períodos o desenvolvimento das formas de relevo e o mecanismo de sedimentação deu-se em ciclos alternados com profundas mudanças climáticas.

As cotas altimétricas dessas superficies variam entre 200 700 metros, abaixo dos pediplanos e, entre 25 - 200 metros abaixo dos pedimentos.

As declividades de $158-208$, em alguns locais e de acima de 208 em outros, demonstram o intenso retalhamento sofrido por essas áreas. (Anexo 3).

os pedimentos correspondem a superfícies ligeiramente inclinadas com a forma de ombreiras.

Essas superficies encontram-se margeando os pediplanos ou, estão embutidas nos piemontes e áreas indiferenciadas. (Anexo 2).

As cotas altimétricas dessas superfícies variam entre 200 700 metros, sendo que nas porções mais elevadas margeam os pediplanos.

Os pedimentos apresentam declividades predominantes de 58 108 e, com mais de 108. (Anexo 3).

Os morros altos dissecados, configuram uma pequena região ao norte da região montanhosa litorânea. (Anexo 2). Essa área é composta por uma elevação granítica intensamente dissecada, quase individualizada no terreno.

As cotas altimétricas variam entre 20 - 377 metros, fazendo com que a área ressalte na topografia.

As suas declividades crescem da base para o topo, sendo predominantemente de 5\% - $10 \%$ na base e subindo acima de $20 \%$ no topo.

os vales são representados por áreas com encostas ingremes, onde as declividades são acentuadas. Situam-se na porção oeste da 
área estudada, encaixados nas rochas do complexo gnáissico migmatítico costeiro. (Anexo 2 ).

A existência de diáclases, com direções paralelas aos eixos dos vales, nesses locais, indica que estas possibilitaram o encaixamento dos rios e alargamento dos vales. Isto permitiu também, a configuração das encostas íngremes desses vales.

As encostas desses vales, apresentam declividades variando entre $108-158$ e $158-208$. (Anexo 3).

As cotas altimétricas mais baixas são de 20 metros, e as mais elevadas de 100 metros.

A região da planície litorânea abrange cotas entre 0 - 20 metros, apresentando morros e colinas de diversos tamanhos que dela sobressaem. Configura uma região plana e suave ondulada com elevações de até 155 metros, que se destacam na topografia.

Nesta região, que se estende a leste da região montanhosa litorânea, ocupando a maior extensão da área estudada, foram distinguidas sete unidades geomórficas. Essas unidades são as seguintes: morros, colinas, planícies aluviais, planície de restinga alta, planície de restinga média, planície de restinga baixa e mangue. (Anexo 2).

Os morros, são elevações sustentadas por rochas do Complexo gnássico migmatítico, que sobressaem na planície. Distribuem-se espalhados na porção noroeste da região da planicie litorânea, bem como, na ilha do Mel e ilha da Cotinga. (Anexo 2).

Esses morros, geralmente de substrato granítico, apresentam cotas altimétricas entre 20 - 155 metros e, formas alongadas e arredondadas.

Suas declividades aumentam da base em direção ao topo. As declividades nas partes baixas variam de 58 - 108, passando a serem maiores que 208 no topo. (anexo 3 ).

As colinas possuem um relevo mais suave que os morros. As suas cotas altimétricas máximas atingem 62 metros, porém, em média suas cotas são de 40 metros.

As litologias que constituem essas elevações são granitos, granitos com intrusões básicas e sedimentos da Formação Alexandra. Em alguns locais, essas litologias afloram ao nível do terreno, não 
ultrapassando cotas de 20 metros, portanto, não sobressaindo no relevo.

As colinas encontram-se margeando a planicie aluvial, na porção noroeste da área estudada. (Anexo 2). As suas declividades variam de 58 - 108 (Anexo 3).

As diferenças de cotas altimétricas e declividades entre as colinas e os morros, reside em suas características litológicas e na existência de estruturas geológicas capazes de influenciar no processo intempérico.

Assim, as rochas menos resistentes e com maior número de diáclases, são mais rebaixadas pelo intemperismo diferencial, configurando elevações de cotas mais baixas.

As planícies aluviais, englobam áreas compostas por depósitos fluviais de diferentes tipos e formas.

Essas áreas encontram-se margeando a região montanhosa Iitorânea, em sua extremidade leste, e os principais rios. (Anexo 2). As cotas altimétricas dessas áreas variam de 0 - 20 metros, estando as porções mais baixas, próximas aos rios, sujeitas a inundações.

As declividades predominantes variam de $0 \%$ - 58, ocorrendo locais com 58 - 108. (Anexo 3 ).

A planície de restinga alta configura uma faixa com direção nordeste, disposta a leste da área estudada e, porções menores nas ilhas e a sudeste no continente. (Anexo 2).

Nesse local as cotas altimétricas variam de 12 - 20 metros. Suas declividades, inferiores a 58, configuram uma região plana. (Anexo 3).

A planície de restinga alta é composta por depósitos arenosos gerados pelas variações do mar durante o Quaternário.

A planície de restinga média e baixa, dispõem-se em cotas altimétricas mais baixas que as da planície de restinga alta. As cotas altimétricas da planicie de restinga média, variam entre $6-12$ metros, e da planície de restinga baixa entre 0 - 6 metros.

As declividades dessas planícies, são semelhantes as da planicie de restinga alta, contudo os sedimentos que as constituem variam. 
Nas planícies de restinga média e baixa ocorrem depósitos areno síltico argilosos relacionados com o avanço dos mares sobre o continente no Quaternário, além dos depósitos arenosos.

A planicie de restinga baixa, ocupa na área em estudo, as porções mais baixas, no litoral ou nas regiões mais internas do continente. (Anexo 2).

A planicie de restinga média distribui-se margeando a planície de restinga alta, e ocupa uma grande extensão na porção central da região em apreço. (anexo 2).

Os impedimentos ditados pela geomorfologia, em relação a locação de áreas para aterros sanitários, reside nas declividades altas, segundo a CETESB (1985).

Os locais com terrenos acidentados, muitas vezes, se prestam à locação de aterros sanitários, pois os resíduos são colocados junto à base do desnivel já existente.

A operação desse tipo de aterro sanitário, que pode ocupar locais como grotas, fundos de vale e pedreiras extintas, entre outros, é explilcada por LEITE (1991) e, mais recentemente por FUZZARO (1994).

Os cuidados a serem tomados, em locais com terrenos acidentados, devem ser maiores em relação a possiveis movimentos de massas e fluxos superficiais de água em épocas chuvosas.

Em casos extremos, em locais com declividades de até $20 \%$, podem ser executadas obras de terraplanagem para a instalação de aterros sanitários, procedimento previsto pela N.B.R.-10157 (A.B.N.T., 1987).

Tendo como base a geologia e a geomorfologia da área estudada, recomenda-se como limite máximo a declividade de 108, para as áreas destinadas a locação de aterros sanitários.

Assim, a região da planície litorânea, em relação às declividades, não apresenta restrições para a locação de aterros sanitários, tendo em vista as declividades de 08 - 58 predominarem. Exceção deve ser feita as zonas de mangue, pois apresentam baixas declividades, e não se prestam para a locação de aterros sanitários, devido a serem passíveis de alagamento. 
Os morros e colinas, que sobressaem na topografia da planicie litorânea, também, não configuram elementos de restrição, desde que possuam áreas com declividades inferiores a 108 .

$\mathrm{Na}$ região montanhosa litorânea, existem locais com declividades baixas, como os pedimentos e pediplanos, porém, a situação destas feições no relevo é problemática. Esses problemas são representados pelas altitudes dessas feições geomórficas, e pela posição que ocupam na topografia.

As altitudes elevadas, dificultam $\circ$ acesso e permitem uma ação intensiva dos processos intempéricos, que são atuantes na região. Ressalta-se a ação da pluviosidade, cujos índices são elevados no local.

- posicionamento dessas feições na meia encosta e nas cotas mais elevadas do terreno, thes configura uma situação de risco, tendo em vista constantes movimentos de massas, nesas áreas da região montanhosa litorânea.

Os piemontes e áreas indiferenciadas, são representados por elevações com relevo enérgico, sem formas definidas e declividades elevadas, configurando regiões inadequadas para locação de aterros sanitários.

Os vales, poderiam em alguns locais, serem usados para disposição de resíduos. Contudo, apresentam rios encaixados e um grande número de diáclases, fatores que em certos locais, restringem seu uso para esse fim.

5.2.3. Hidrogeologia.

$\mathrm{Na}$ área em estudo estão presentes dois tipos bastante diferentes de aqüiferos: o aqüifero fissural representado por rochas do Complexo gnáissico migmatítico do Pré-Cambriano e $\circ$ aqüifero intersticial representado por sedimentos do Terciário e do Quaternário.

- aqüífero representado pelas rochas pré-cambrianas, apresenta um grande número de diáclases e falhas, em sua grande maioria abertas. Essas estruturas configuram o meio poroso para a circulação da água subterrânea. 
As principais direções dessas estruturas variam entre $N-S e$ N10W, e seus mergulhos são para $\mathrm{E} e \mathrm{NE}$, indicando o fluxo da água nelas contida.

No anexo 4, visualiza-se que o sentido geral do fluxo da agua deste aqüífero é para leste, concordando com as direções de inclinação das estruturas medidas.

$\mathrm{Na}$ tabela 2 e 3 , onde estão representados os níveis potenciométricos dos poços tipo cacimbas e poços tubulares, respectivamente. Observa-se nessas tabelas, que os poços cadastrados sobre as rochas pré-cambrianas possuem niveis potenciométricos que variam de 6,0 - 46,0 metros de profundidade. Supõe-se contudo, que essas profundidades sejam maiores, em direção as maiores altitudes da região de afloramento dessas rochas.

Nota-se que existe uma concentração de poços localizados na extremidade leste, da região de afloramento das rochas précamorianas. (Anexo 4). Nesse local, de cotas altimétricas mais baixas, existem poços tubulares que alcançam a rocha fresca, e uma grande quantidade de poços cacimbas que obtêm água do regolito.

o regolito de baixa permeabilidade $\left(10^{-6} \mathrm{~cm} / \mathrm{s}\right)$, produto da alteração das rochas pré-cambrianas, apresenta distribuição espacial e profundidades descontínuas. Assim, onde é mais espesso e contínuo, forma áreas de resurgência.

os poços tubulares que atingem a rocha fresca, penetrando-a, são alimentados por água reservada nos sistemas de fraturas existentes. Esses poços, apresentam os níveis estáticos mais profundos entre os poços cadastrados. 


\begin{tabular}{|c|c|c|c|c|c|c|}
\hline \multirow{2}{*}{$\begin{array}{c}\mathrm{N}^{0} \\
\text { DO } \\
\text { POÇO }\end{array}$} & \multicolumn{2}{|c|}{ LOCALIZAÇÃO } & \multirow{2}{*}{$\begin{array}{c}\text { COTA DA } \\
\text { BOCA DO } \\
\text { POÇO } \\
(\mathrm{m})\end{array}$} & \multirow{2}{*}{$\begin{array}{l}\text { PROFUNDIDADE } \\
\text { DO LENÇOL } \\
\text { FREÁTICO } \\
\text { (m) }\end{array}$} & \multirow{2}{*}{$\begin{array}{l}\text { NIVEL } \\
\text { POTENCIO } \\
\text { MÉTRICO } \\
\text { (m) }\end{array}$} & \multirow{2}{*}{$\begin{array}{c}\text { TIPO } \\
\text { DE } \\
\text { SUBSTRATO }\end{array}$} \\
\hline & U.T.M. & U.T.M. & & & & \\
\hline 1 & 761,88 & 7169,87 & 7,0 & 1,5 & 5,5 & $\begin{array}{l}\text { SEDIMENTOS } \\
\text { ARENOSOS }\end{array}$ \\
\hline 2 & 754,98 & 7161,45 & 10,0 & 2,3 & 7,7 & $\begin{array}{l}\text { SEDIMENTOS } \\
\text { ARENOSOS }\end{array}$ \\
\hline 3 & 735,53 & 7174,48 & 15,0 & 9,0 & 6,0 & $\begin{array}{l}\text { GRANITO } \\
\text { ALTERADO }\end{array}$ \\
\hline 4 & 735,04 & 7170,98 & 20,0 & 4,0 & 16,0 & $\begin{array}{l}\text { GRANITO } \\
\text { ALTERADO }\end{array}$ \\
\hline 5 & 738,03 & 7167,84 & 15,0 & 8,5 & 6,5 & $\begin{array}{l}\text { GRANITO } \\
\text { ALTERADO } \\
\end{array}$ \\
\hline 6 & 738,21 & 7167,08 & 16,0 & 9,0 & 7,0 & $\begin{array}{l}\text { GRANITO } \\
\text { ALTERADO }\end{array}$ \\
\hline 7 & 738,18 & 7165,20 & 18,0 & 10,0 & 8,0 & $\begin{array}{l}\text { GRANITO } \\
\text { ALTERADO }\end{array}$ \\
\hline 8 & 741,25 & 7165,12 & 13,0 & 9,0 & 4,0 & $\begin{array}{c}\text { ALUVIÃO } \\
\text { INDIFERENCIADO }\end{array}$ \\
\hline 9 & 741,98 & 7163,28 & 10,0 & 2,0 & 8,0 & $\begin{array}{c}\text { ALUVIÃO } \\
\text { INDIFERENCIADO }\end{array}$ \\
\hline 10 & 741,74 & 7161,41 & 25,0 & 3,0 & 22,0 & $\begin{array}{l}\text { GRANITO } \\
\text { ALTERADO }\end{array}$ \\
\hline 11 & 742,32 & 7161,96 & 8,0 & 2,0 & 6,0 & $\begin{array}{c}\text { ALUVIÃO } \\
\text { INDIEERENCIADO }\end{array}$ \\
\hline 12 & 741,25 & 7161,21 & 6,0 & 2,5 & 3,5 & $\begin{array}{c}\text { ALUVIÂO } \\
\text { INDIEERENCIADO }\end{array}$ \\
\hline 13 & 743,62 & 7158,14 & 10,0 & 2,0 & 8,0 & $\begin{array}{c}\text { ALUVIÃO } \\
\text { INDIFERENCIADO }\end{array}$ \\
\hline
\end{tabular}

TABELA 2 - Dados utilizados para o traçado das isolinhas da superficie potenciométrica, aferidos em poços tipo cacimba. 


\begin{tabular}{|c|c|c|c|c|c|c|}
\hline \multirow{2}{*}{$\begin{array}{c}N^{0} \\
\text { DO } \\
\text { POÇO }\end{array}$} & \multicolumn{2}{|c|}{ IOCALIZAÇÃO } & \multirow{2}{*}{$\begin{array}{c}\text { COTA DA } \\
\text { BOCA DO } \\
\text { POÇO } \\
\text { (m) }\end{array}$} & \multirow{2}{*}{$\begin{array}{l}\text { PROEUNDIDADE } \\
\text { DO NÍVEI } \\
\text { DE ÁGUA } \\
(\mathrm{m})\end{array}$} & \multirow{2}{*}{$\begin{array}{l}\text { NÍVEL } \\
\text { POTENCIO } \\
\text { MÉTRICO } \\
(\mathrm{m})\end{array}$} & \multirow{2}{*}{$\begin{array}{c}\text { TIPO } \\
\text { DE } \\
\text { SUBSTRATO }\end{array}$} \\
\hline & U.T.M. & U.T.M. & & & & \\
\hline 1 & 746,98 & 7176,00 & 2,0 & 0,5 & 1,5 & $\begin{array}{l}\text { SEDIMENTOS } \\
\text { ARENOSOS }\end{array}$ \\
\hline 2 & 747,71 & 7176,27 & 2,0 & 0,9 & 1,1 & $\begin{array}{l}\text { SEDIMENTOS } \\
\text { ARENOSOS }\end{array}$ \\
\hline 3 & 749,12 & 7176,71 & 2,0 & 1,0 & 1,0 & $\begin{array}{l}\text { SEDIMENTOS } \\
\text { ARENOSOS }\end{array}$ \\
\hline 4 & 750,00 & 7176,25 & 2,0 & 1,2 & 0,8 & $\begin{array}{l}\text { SEDIMENTOS } \\
\text { ARENOSOS }\end{array}$ \\
\hline 5 & 750,00 & 7175,00 & 3,0 & 2,6 & 0,4 & $\begin{array}{l}\text { SEDIMENTOS } \\
\text { ARENOSOS }\end{array}$ \\
\hline 6 & 748,91 & 7173,68 & 3,0 & 0,9 & 2,1 & $\begin{array}{l}\text { SEDIMENTOS } \\
\text { ARENOSOS }\end{array}$ \\
\hline 7 & 747,98 & 7173,22 & 3,5 & 3,2 & 0,3 & $\begin{array}{l}\text { SEDIMENTOS } \\
\text { ARENOSOS }\end{array}$ \\
\hline 8 & 747,72 & 7172,61 & 4,0 & 2,9 & 1,1 & $\begin{array}{l}\text { SEDIMENTOS } \\
\text { ARENOSOS }\end{array}$ \\
\hline 9 & 744,20 & 7171,22 & 10,0 & 3,0 & 7,0 & $\begin{array}{l}\text { SEDIMENTOS } \\
\text { ARENOSOS }\end{array}$ \\
\hline 10 & 744,51 & 7170,56 & 10,0 & 3,2 & 6,8 & $\begin{array}{l}\text { SEDIMENTOS } \\
\text { ARENOSOS }\end{array}$ \\
\hline 11 & 743,27 & 7170,86 & 10,0 & 3,5 & 6,5 & $\begin{array}{l}\text { SEDIMENTOS } \\
\text { ARENOSOS }\end{array}$ \\
\hline 12 & 743,85 & 7169,49 & 10,0 & 2,6 & 7,4 & $\begin{array}{l}\text { SEDIMENTOS } \\
\text { ARENOSOS }\end{array}$ \\
\hline 13 & 740,31 & 7170,00 & 15,0 & 10,0 & 5,0 & $\begin{array}{l}\text { DEPOSITOS ALUVIAIS } \\
\text { INDIFERENCIADOS }\end{array}$ \\
\hline 14 & 739,00 & 7170,00 & 18,0 & 11,0 & 7,0 & $\begin{array}{c}\text { FORMAÇÃO } \\
\text { AIEXANDRA } \\
\end{array}$ \\
\hline 15 & 749,47 & 7172,60 & 7,0 & 2,0 & 5,0 & $\begin{array}{l}\text { SEDIMENTOS } \\
\text { ARENOSOS }\end{array}$ \\
\hline 16 & 741,00 & 7163,27 & 50,0 & 4,0 & 46,0 & $\begin{array}{c}\text { COMPLEXO GNASSICO } \\
\text { MIGMATITICO } \\
\text { COSTEIRO }\end{array}$ \\
\hline 17 & 753,28 & 7154,69 & 3,0 & 1,0 & 2,0 & $\begin{array}{l}\text { SEDIMENTOS } \\
\text { ARENOSOS }\end{array}$ \\
\hline 18 & 753,31 & 7155,60 & 13,0 & 0,3 & 12,1 & $\begin{array}{l}\text { SEDIMENTOS } \\
\text { ARENOSOS }\end{array}$ \\
\hline 19 & 753,78 & 7155,00 & 3,0 & 1,5 & 1,5 & $\begin{array}{l}\text { SEDIMENTOS } \\
\text { ARENOSOS }\end{array}$ \\
\hline 20 & 754,51 & 7156,83 & 3,0 & 1,1 & 1,9 & $\begin{array}{l}\text { SEDIMENTOS } \\
\text { ARENOSOS }\end{array}$ \\
\hline 21 & 753,62 & 7158,56 & 6,0 & 1,6 & 4,4 & $\begin{array}{l}\text { DEPOSITOS ALUVIAIS } \\
\text { INDIFERENCIADOS }\end{array}$ \\
\hline
\end{tabular}

TABELA 3 - Dados utilizados para o traçado das isolinhas da superfície potenciométrica, aferidos em poços tubulares. Fonte: Modificado de GIUSTI (1994). 


\begin{tabular}{|c|c|c|c|c|c|c|}
\hline \multirow{2}{*}{$\begin{array}{c}\mathrm{N} \underline{\hat{Q}} \\
\text { DO } \\
\text { POÇO }\end{array}$} & \multicolumn{2}{|c|}{ LOCALIZAÇÃO } & \multirow{2}{*}{$\begin{array}{c}\text { COTA DA } \\
\text { BOCA DO } \\
\text { POÇO } \\
(\mathrm{m})\end{array}$} & \multirow{2}{*}{$\begin{array}{c}\text { PROFUNDIDADE } \\
\text { DO NÍVEL } \\
\text { DE ÁGUA } \\
(\mathrm{m})\end{array}$} & \multirow{2}{*}{$\begin{array}{l}\text { NIVEL } \\
\text { POTENCIO } \\
\text { MÉTRICO } \\
(\mathrm{m})\end{array}$} & \multirow{2}{*}{$\begin{array}{c}\text { TIPO } \\
\text { DE } \\
\text { SUBSTRATO }\end{array}$} \\
\hline & U.T.M. & U.T.M. & & & & \\
\hline 22 & 756,63 & 7160,00 & 9,0 & 1,2 & 7,8 & $\begin{array}{l}\text { SEDIMENTOS } \\
\text { ARENOSOS }\end{array}$ \\
\hline 23 & 755,59 & 7160,22 & 9,0 & 0,9 & 8,1 & $\begin{array}{l}\text { SEDIMENTOS } \\
\text { ARENOSOS }\end{array}$ \\
\hline 24 & 760,79 & 7170,96 & 6,0 & 0,8 & 5,2 & $\begin{array}{l}\text { SEDIMENTOS } \\
\text { ARENOSOS }\end{array}$ \\
\hline 25 & 763,65 & 7167,33 & 5,0 & 1,1 & 3,9 & $\begin{array}{l}\text { SEDIMENTOS } \\
\text { ARENOSOS }\end{array}$ \\
\hline 26 & 764,92 & 7168,23 & 5,0 & 1,0 & 4,0 & $\begin{array}{l}\text { SEDIMENTOS } \\
\text { ARENOSOS }\end{array}$ \\
\hline 27 & 769,51 & 7175,82 & 15,0 & 1,8 & 13,2 & $\begin{array}{c}\text { COMPLEXO GNAISSTCO } \\
\text { MIGMATITICO } \\
\text { COSTEIRO } \\
\end{array}$ \\
\hline 28 & 745,96 & 7171,00 & 4,0 & 1,5 & 2,5 & $\begin{array}{l}\text { SEDIMENTOS } \\
\text { ARENOSOS }\end{array}$ \\
\hline 29 & 736,79 & 7170,68 & 52,0 & 8,0 & 44,0 & $\begin{array}{l}\text { COMPLEXO GNAISSICO } \\
\text { MIGMATITICO } \\
\text { COSTEIRO }\end{array}$ \\
\hline 30 & 750,87 & 7174,24 & 6,0 & 1,8 & 4,2 & $\begin{array}{l}\text { SEDIMENTOS } \\
\text { ARENOSOS }\end{array}$ \\
\hline 31 & 746,49 & 7173,61 & 2,0 & 1,6 & 0,4 & $\begin{array}{l}\text { SEDIMENTOS } \\
\text { ARENOSOS } \\
\end{array}$ \\
\hline 32 & 746,11 & 7164,82 & 6,0 & 3,0 & 3,0 & $\begin{array}{l}\text { SEDIMENTOS } \\
\text { ARENOSOS }\end{array}$ \\
\hline 33 & 747,81 & 7162,18 & 6,0 & 3,1 & 2,9 & $\begin{array}{l}\text { SEDIMENTOS } \\
\text { ARENOSOS }\end{array}$ \\
\hline 34 & 752,46 & 7156,45 & 6,0 & 1,6 & 4,4 & $\begin{array}{l}\text { DEPOSITOS ALUVIAIS } \\
\text { INDIFERENCIADOS }\end{array}$ \\
\hline 35 & 751,46 & 7156,37 & 6,0 & 2,3 & 3,7 & $\begin{array}{l}\text { DEPÓSITOS ALUVIAIS } \\
\text { INDIFERENCIADOS }\end{array}$ \\
\hline 36 & 759,91 & 7164,40 & 3,0 & 1,1 & 1,9 & $\begin{array}{l}\text { SEDIMENTOS } \\
\text { ARENOSOS }\end{array}$ \\
\hline 37 & 760,70 & 7165,06 & 2,0 & 1,0 & 1,0 & $\begin{array}{l}\text { SEDIMENTOS } \\
\text { ARENOSOS }\end{array}$ \\
\hline 38 & 761,18 & 7165,26 & 2,0 & 1,2 & 0,8 & $\begin{array}{l}\text { SEDIMENTOS } \\
\text { ARENOSOS }\end{array}$ \\
\hline 39 & 738,72 & 7171,87 & 8,0 & 6,0 & 2,0 & $\begin{array}{c}\text { FORMAÇÃO } \\
\text { ALEXANDRA }\end{array}$ \\
\hline 40 & 740,48 & 7171,26 & 10,0 & 8,0 & 2,0 & $\begin{array}{l}\text { COMPLEXO GNAISSICO } \\
\text { MIGMATITICO } \\
\text { COSTEIRO } \\
\end{array}$ \\
\hline 41 & 741,22 & 7166,76 & 44,0 & 7,5 & 36,5 & $\begin{array}{l}\text { COMPLEXO GNAISSICO } \\
\text { MIGMATITICO } \\
\text { COSTEIRO } \\
\end{array}$ \\
\hline
\end{tabular}

TABELA 3 (Continuação) - Dados utilizados para o traçado das isolinhas da superficie potenciométrica, aferidos em poços tubulares

Fonte: Modificado de GIUSTI (1994) 
As vazões dos poços situados em rochas pré-cambrianas, na região litorânea paranaense, segundo GIUSTI (1994), variam de 1,8 a $25,3 \mathrm{~m}^{3} / \mathrm{h}$, dependendo das características estruturais dessas rochas.

Portanto, o aqüífero fissural configura um importante reservatório de água regional, merecendo ser protegido em suas áreas de recarga. Essa proteção se faz necessária nos locais de fraturas abertas, ou nas áreas de pouca cobertura de solos. Por essa razão, considerou-se as áreas de afloramento das rochas pré-cambrianas, como de vulnerabilidade média. (Anexo 5).

os granitos que afloram na região da planicie litorânea, sobressaindo na paisagem, podem se apresentar sem falhas e diáclases, ou cortados por essas estruturas. Nos casos em que não apresentam estruturas, configuram-se impermeáveis, e foram considerados como áreas de aqüiferos de baixa vulnerabilidade. Quando diaclasados, representam aqüíferos de vulnerabilidade média. (Anexo 5).

Nos locais onde afloram as rochas do Complexo gnáissico migmatitico costeiro, uma das saidas do sistema hidrogeológico são os rios que drenam a área, nos locais de maior impermeabilidade. Esses rios apresentam um sentido geral de fluxo para leste.

Em dois desses rios, um afluente do rio das pombas, outro, afluente do rio Ribeirão, existem captações de água. (Anexo 4). A captação no afluente do rio das pombas, abastece a praia de Caiobá, enquanto a captação do afluente do rio Ribeirão, abastece a região de Praia de Leste em Paranaguá.

- aqüífero intersticial, bem evidenciado na região da planicie litorânea, apresenta variações locais, coordenadas pelos tipos de sedimentos depositados.

$\mathrm{Na}$ região de ocorrência da Formação Alexandra, onde as camadas arenosas estão intercaladas em material argiloso, configurase um aqüífero confinado por aquicludes.

A espessura das camadas arenosas saturadas com água é variável, segundo BIGARELIA (1978), o conjunto das camadas arenosas e seus aquicludes podem atingir espessuras superiores a 65 metros.

Características semelhantes são observadas nos locais de ocorrência de cascalhos, dos depósitos areno-siltico-argilosos, colúvios e nos depósitos aluviais indiferenciados. 
Os depósitos aluviais indiferenciados e os colúvios são provinientes da decomposição de feldspatos e outros minerais das rochas cristalinas, o que possibilitou seu elevado teor de argila.

Esses depósitos, apresentam camadas de areias argilosas e pedregulhos, areno-argilosas e argilo-arenosas saturadas por água, correspondendo aos cascalhos, depósitos areno-siltico-argilosos, depósitos de aluviões indiferenciados e colúvios, respectivamente.

Nesses locais, o aqüifero apresenta-se semi-confinado por aquitardes.

- nível potenciométrico verificado nos poços cadastrados sobre a Formação Alexandra, varia de 6,0 - 7,0 metros. (Tabela 3). Nos locais de exposição dos depósitos aluviais indiferenciados e colúvios, o nivel potenciométrico varia de $3,5-8,0$ metros de profundidade. (Tabela 2 e 3 ). Sobre os cascalhos e depósitos arenosiltico-argilosos, as linhas isopotenciais, indicam profundidades entre $0,0-6,0$ metros de profundidade.

A Formação Alexandra aflora na porção nordeste das rochas pré-cambrianas, e em alguns locais, o sentido de fluxo das águas contidas em suas rochas, se faz em direção aos rios próximos.

Em outros locais, onde a Formação Alexandra configura colinas, observa-se um direcionamento de fluxo do seu aquífero para nordeste. (Anexo 4).

Nos aquíferos semi-confinados, o sentido do fluxo é para as cotas altimétricas mais baixas, onde se encontram rios, para os quais convergem a drenagem superficial. (Anexo 4).

Esses aqüíferos confinados e semi-confinados, por apresentarem aquicludes e aquitardes com permeabilidade de $10^{-4}$ a $10^{-6}$ $\mathrm{cm} / \mathrm{s}$, acham-se fisicamente desconectados do meio ambiente e suas águas melhor protegidas. Contudo, em alguns locais representam áreas de vulnerabilidade.

Assim, o aquiifero da Formação Alexandra, quando está configura colinas com grande número de diáclases, foi considerado de vulnerabilidade média, e nos locais mais planos onde não ocorrem fraturas, de vulnerabilidade baixa. (Anexo 5). Da mesma forma, os aqüiferos dos cascalhos, dos depósitos areno-síltico-argilosos, dos depósitos aluviais indiferenciados e colúvios, foram considerados de vulnerabilidade média, nos locais baixos próximos aos rios ou a linha 
de costa, onde estão sujeitos a serem cobertos por água. Nos locais mais elevados apresentam vulnerabilidade baixa. (Anexo 5 ).

Nas áreas ocupadas pelos sedimentos arenosos marinhos, o aquífero apresenta-se razo com níveis potenciométricos variando de 0,3 - 12,1 metros, configurando um aqüífero livre.

No quadro 2 , visualiza-se nos perfis geo-elétricos levantados, as variabilidades de profundidades do lençol freático deste aqüífero livre, bem como, a configuração do aquitarde nos depósitos aluviais indiferenciados, na sondagem elétrica (S.E.) n으. 5 .

$\mathrm{Na}$ tabela 4, observa-se as profundidades dos níveis potenciométricos, obtidos por sondagem elétrica e verifica-se que esses valores não são discrepantes com os dados obtidos através dos poços cadastrados, e representados nas tabelas 2 e 3 .

A permeabilidade dos sedimentos arenosos, nos quais se configura o aquífero livre, é elevada $\left(10^{-3} \mathrm{~cm} / \mathrm{s}\right)$, permitindo que as infiltrações diretas das chuvas que caem sobre suas áreas de exposição, sejam incorporadas ao mesmo.

Nas porções mais elevadas, devido a alta permeabilidade dos solos e a baixa profundidade do nivel potenciométrico, configuram-se áreas de alta vulnerabilidade. (Anexo 5).

Nos locais mais baixos, onde o nível potenciométrico é menor e começam as zonas de descarga do aqüífero livre, os fluxos exudantes impedem a infiltração, configurando áreas de vulnerabilidade média. (Anexo 5).

Nas áreas mais baixas do aquífero livre, margeando a costa, são explorados vários poços. (Anexo 4). A utilização excessiva desses poços, pode inverter o sentido de fluxo da água nesses locais, e tornar o aqüífero mais vulnerável.

os mangues representam áreas de alta vulnerabilidade dos aqüíferos, pois estão sujeitos a inundação e infiltração da água do mar.

Segundo GIUSTI (1994), as vazões dos poços nos depósitos quaternários variam de 0,5 a $19,8 \mathrm{~m}^{3} / \mathrm{h}$, sendo que a maior incidência de poços secos, ocorre na Eormação Alexandra.

Com relação a locação de áreas para aterros sanitários, não existem normas fixadas que relacionem as características de vulnerabi 


\begin{tabular}{|c|c|c|c|c|}
\hline $\begin{array}{c}N^{0} \\
D A \\
\text { SONDAGEM }\end{array}$ & PROFUNDIDADE & $\begin{array}{l}\text { RESISTIVIDADE } \\
(O \mathrm{hm} \times \mathrm{m})\end{array}$ & & $\begin{array}{c}\text { PROFUNDIDADE } \\
\text { DO LENÇOL } \\
\text { FREÁTICO } \\
(\mathrm{m})\end{array}$ \\
\hline \multirow{4}{*}{1} & $0,0-5,0$ & 480 & $\begin{array}{c}\text { AREIA EINA NÃO } \\
\text { SATURADO }\end{array}$ & \multirow{4}{*}{5,0} \\
\hline & $5,0-7,0$ & 195 & $\begin{array}{c}\text { AREIA FINA SATURADA } \\
\text { COM AGUA DOCE }\end{array}$ & \\
\hline & $7,0-9,0$ & 50 & $\begin{array}{l}\text { AREIA FINA } \\
\text { ARGILOSA }\end{array}$ & \\
\hline & $>9,0$ & 48 & $\begin{array}{c}\text { ARGILA ORGANNICA } \\
\text { E AREIA }\end{array}$ & \\
\hline \multirow{4}{*}{2} & $0,0-3,2$ & 490 & $\begin{array}{c}\text { AREIA } \\
\text { INSATURADA }\end{array}$ & \multirow{4}{*}{3,2} \\
\hline & $3,2-5,0$ & 160 & $\begin{array}{l}\text { AREIA FINA SATURADA } \\
\text { COM AGUA DOCE }\end{array}$ & \\
\hline & $5,0-10,0$ & 56 & $\begin{array}{l}\text { AREIA FINA } \\
\text { ARGILOSA }\end{array}$ & \\
\hline & $>10,0$ & 48 & $\begin{array}{l}\text { ARGIIA COM } \\
\text { AREIA }\end{array}$ & \\
\hline \multirow{4}{*}{3} & $0,0-5,7$ & 500 & $\begin{array}{l}\text { AREIA NÄO } \\
\text { SATURADA }\end{array}$ & \multirow{4}{*}{5,7} \\
\hline & $5,7-8,0$ & 160 & $\begin{array}{l}\text { AREIA SATURADA } \\
\text { COM AGUA DOCE }\end{array}$ & \\
\hline & $8,0-10,0$ & 50 & $\begin{array}{l}\text { AREIA FINA } \\
\text { ARGILOSA } \\
\end{array}$ & \\
\hline & $>10,0$ & 48 & $\begin{array}{l}\text { ARGIIA COM } \\
\text { AREIA }\end{array}$ & \\
\hline \multirow{3}{*}{4} & $0,0-5,5$ & 500 & $\begin{array}{l}\text { AREIA NÄO } \\
\text { SATURADA }\end{array}$ & \multirow{3}{*}{5,5} \\
\hline & $5,5-8,0$ & 150 & $\begin{array}{c}\text { AREIA FINA SATURADA } \\
\text { COM AGUA DOCE } \\
\end{array}$ & \\
\hline & $>8,0$ & 50 & $\begin{array}{l}\text { AREIA FINA } \\
\text { ARGILOSA }\end{array}$ & \\
\hline \multirow{3}{*}{5} & $0,0-2,0$ & 460 & $\begin{array}{l}\text { ARGIIA ARENOSA } \\
\text { NÄO SATURADA }\end{array}$ & \multirow{3}{*}{2,0} \\
\hline & $2,0-5,0$ & 150 & $\begin{array}{l}\text { ARGILA ARENOSA SATU } \\
\text { RADA COM AGUA DOCE }\end{array}$ & \\
\hline & $>5,0$ & 46 & $\begin{array}{c}\text { ARGIIA } \\
\text { ORGANICA } \\
\end{array}$ & \\
\hline \multirow{4}{*}{6} & $0,0-6,5$ & 500 & $\begin{array}{l}\text { AREIA NĀO } \\
\text { SATURADA }\end{array}$ & \multirow{4}{*}{6,5} \\
\hline & $6,5-9,0$ & 160 & $\begin{array}{l}\text { ARE IA SATURADA } \\
\text { COM AGUA DOCE }\end{array}$ & \\
\hline & $9,0-11,0$ & 50 & $\begin{array}{l}\text { AREIA FINA } \\
\text { ARGILOSA }\end{array}$ & \\
\hline & $>11,0$ & 48 & $\begin{array}{l}\text { ARGIIA COM } \\
\text { AREIA }\end{array}$ & \\
\hline
\end{tabular}

QUADRO 2 - Perfis geo-elétricos obtidos através de sondagem por eletro-resistividade. 


\begin{tabular}{|c|c|c|c|c|c|c|}
\hline \multirow{2}{*}{$\begin{array}{c}N^{0} \\
\text { DA } \\
\text { SONDAGEM }\end{array}$} & \multicolumn{2}{|c|}{ LOCAL I ZAÇÃO } & \multirow{2}{*}{$\begin{array}{c}\text { COTA } \\
\text { DO } \\
\text { LOCAL } \\
(\mathrm{m})\end{array}$} & \multirow{2}{*}{\begin{tabular}{|c|} 
PROFUNDIDADE \\
DO LENÇOL \\
EREÁTICO \\
$(\mathrm{m})$
\end{tabular}} & \multirow{2}{*}{$\begin{array}{c}\text { NIVEL } \\
\text { POTENCIO } \\
\text { MÉTRICO } \\
(\mathrm{m})\end{array}$} & \multirow{2}{*}{$\begin{array}{c}\text { TIPO } \\
\text { DE } \\
\text { SUBSTRATO }\end{array}$} \\
\hline & U.T.M. & U.T.M. & & & & \\
\hline 01 & 758,05 & 7168,80 & 10,0 & 5,0 & 5,0 & $\begin{array}{l}\text { SEDIMENTOS } \\
\text { ARENOSOS }\end{array}$ \\
\hline 02 & 752,37 & 7161,15 & 11,0 & 3,2 & 7,8 & $\begin{array}{l}\text { SEDIMENTOS } \\
\text { ARENOSOS }\end{array}$ \\
\hline 03 & 754,76 & 7163,41 & 14,0 & 5,7 & 8,3 & $\begin{array}{l}\text { SEDIMENTOS } \\
\text { ARENOSOS }\end{array}$ \\
\hline 04 & 747,14 & 7164,77 & 8,0 & 5,5 & 2,5 & $\begin{array}{l}\text { SEDIMENTOS } \\
\text { ARENOSOS }\end{array}$ \\
\hline 05 & 750,00 & 7158,36 & 5,5 & 2,0 & 3,5 & $\begin{array}{l}\text { DEPOSITOS ALUVIAIS } \\
\text { INDIFERENCIADOS }\end{array}$ \\
\hline 06 & 743,56 & 7167,74 & 9,0 & 2,5 & 6,5 & $\begin{array}{l}\text { SEDIMENTOS } \\
\text { ARENOSOS }\end{array}$ \\
\hline
\end{tabular}

TABELA 4 - Dados utilizados para o traçado das isolinhas da superfície potenciométrica, obtidos por sondagem elétrica. 
lidade dos aquíferos. A CETESB (1983 e 1985), bem como a A.B.N.T. (1984, 1985) em suas normas, determinam apenas a profundidade do lençol freático.

MENTE et al. (1994), utilizam-se da caracterização da vulnerabilidade natural dos aquíferos, para definir áreas favoráveis à instalação de aterros sanitários.

Assim, os locais que satisfazem as normas da CETESB (1983, $1985)$ e A.B.N.T. (1984, 1985), bem como as características de vulnexabilidade natural dos aqüiferos, relacionadas a hidrogeologia da área em estudo, são aqueles ocupados pelos aqüiferos confinados e semi-confinados.

Esses aquíferos, representados pelos sedimentos da Formação Alexandra, cascalhos, depósitos aluviais indiferenciados e colúvios, onde o nível potenciométrico é superior a 2,0 metros, configuram locais favoráveis para implantação de aterros sanitários. Nesses locais a vulnerabilidade dos aquíferos é baixa.

Nos afloramentos das rochas cristalinas, o aquilfero pode ter condições de vulnerabilidade baixa, nesses locais a implantação de aterro sanitário também é viável.

\subsubsection{Solos}

De acordo com a classificação H.R.B. (Highway Research Board), foram identificados na área solos argilosos (A-7-6) e (A-7$5)$, solos siltosos $(A-4)$, solos areias argilosas $(A-2-6)$, solos predregulhos e areias argilosas $(A-2-4)$ e solos areias siltosas (A-24). (Anexo 6).

Os resultados dos percentuais de areia, silte e argila, e do p.H. dos solos modais, estão colocados no quadro 2 . As caracteristicas granulométricas, o limite de consistência, para sua classificação, bem como os valores de suas permeabilidades estão representados no quadro 3 .

Os solos argilosos (A-7-6), localizam-se no extremo oeste da área, sobre os pediplanos, pedimentos, morros dissecados e morros (Anexo 6).

Esses solos são produto da alteração das rochas précambrianas e mesozóicas, existentes no local, e apresentam distribuição espacial e espessuras irregulares. Nas declividades 


\begin{tabular}{|c|c|c|c|c|c|c|}
\hline \multirow[t]{2}{*}{ PONTO } & \multirow[t]{2}{*}{ CAMADA } & \multicolumn{3}{|c|}{$\begin{array}{l}\text { GRANULOME'TRIA } \\
(8)\end{array}$} & \multirow{2}{*}{$\begin{array}{l}\mathrm{p} . \mathrm{H} . \\
(\mathrm{H} 2 \mathrm{O})\end{array}$} & \multirow{2}{*}{$\begin{array}{c}\text { CLASSTEICAÇÃO } \\
\text { H.R.B. }\end{array}$} \\
\hline & & AREIA & SILTE & ARGILA & & \\
\hline \multirow{3}{*}{1} & $\mathrm{a}$ & 54,0 & 16,0 & 30,0 & 5,4 & A-7-6-Solo argiloso \\
\hline & $\mathrm{b}$ & 28,0 & 18,0 & 54,0 & 5,6 & A-7-6 - Solo argiloso \\
\hline & C & 28,0 & 18,0 & 54,0 & 5,6 & A-7-6 - Solo argiloso \\
\hline \multirow{3}{*}{2} & $a$ & 50,0 & 20,0 & 30,0 & 5,3 & A-7-5 - Solo argiloso \\
\hline & $\mathrm{b}$ & 46,0 & 14,0 & 40,0 & 5,5 & A-7-5 - Solo argiloso \\
\hline & $C$ & 46,0 & 14,0 & 40,0 & 5,5 & A-7-5 - solo argiloso \\
\hline \multirow{3}{*}{17} & a & 25,0 & 70,0 & 5,0 & 4,8 & - Solo siltoso \\
\hline & $\mathrm{b}$ & 20,0 & 78,0 & 2,0 & 5,1 & - Solo siltoso \\
\hline & C & 20,0 & 78,0 & 2,0 & 5,1 & - Solo siltoso \\
\hline \multirow{3}{*}{7} & a & 35,0 & 28,0 & 30,0 & 4,7 & A-2-6 - Solo areia argilosa \\
\hline & $\mathrm{b}$ & 37,0 & 30,0 & 33,0 & 4,3 & A-2-6 - Solo areia argilosa \\
\hline & C & 37,0 & 30,0 & 33,0 & 4,3 & A-2-6 - Solo areia argilosa \\
\hline \multirow{3}{*}{9} & a & 70,0 & 15,0 & 20,0 & 4,8 & $\begin{array}{c}\mathrm{A}-2-4 \text { - } \\
\text { Solos pedregulhos e areia } \\
\text { argilosa }\end{array}$ \\
\hline & $\mathrm{b}$ & 80,0 & 5,0 & 10,0 & 4,5 & $\begin{array}{c}\text { A-2-4 - Solos pedregulhos e areia } \\
\text { argilosa }\end{array}$ \\
\hline & c & 80,0 & 5,0 & 10,0 & 4,5 & \begin{tabular}{|c} 
A-2-4 - $\begin{array}{c}\text { Solos pedregulhos e areia } \\
\text { argilosa }\end{array}$ \\
\end{tabular} \\
\hline \multirow{3}{*}{14} & $a$ & 92,0 & 6,0 & 2,0 & 4,3 & A-2-4 - Solo areia siltosa \\
\hline & $\mathrm{b}$ & 96,0 & 4,0 & 0,0 & 4,0 & A-2-4 - Solo areia siltosa \\
\hline & C & 96,0 & 4,0 & 0,0 & 4,0 & A-2-4 - Solo areia siltosa \\
\hline
\end{tabular}

QUADRO 3 - Características granulométricas e valores de p.H. dos solos modais da área estudada. 


\begin{tabular}{|c|c|c|c|c|c|c|c|c|c|}
\hline \multirow[t]{2}{*}{ PONTO } & \multirow[t]{2}{*}{ CAMADA } & \multirow{2}{*}{$\begin{array}{c}\text { EROFUNDI } \\
\text { DADE } \\
(\mathrm{cm}) \\
\end{array}$} & \multicolumn{3}{|c|}{$\begin{array}{l}\text { GRANULOMETRIA } \\
(8 \text { PASSADA) }\end{array}$} & \multicolumn{2}{|c|}{\begin{tabular}{|c|} 
LIMITE DE \\
CONSISTENCIA
\end{tabular}} & PERMEABI & \multirow[t]{2}{*}{ CLASS IFI CAÇÃO } \\
\hline & & & $\begin{array}{c}2,00 \\
\mathrm{~mm} \\
(10) \\
\end{array}$ & $\begin{array}{c}0,420 \\
\text { mm } \\
(40)\end{array}$ & $\begin{array}{c}0,074 \\
\mathrm{~mm} \\
(200)\end{array}$ & $\begin{array}{l}\text { L.L. } \\
(8)\end{array}$ & $\begin{array}{l}\text { I.P. } \\
(8)\end{array}$ & $\begin{array}{l}\text { LIDADE } \\
(\mathrm{cm} / \mathrm{s})\end{array}$ & \\
\hline \multirow{3}{*}{1} & $\mathrm{a}$ & $0-20$ & 97,6 & 69,5 & 43,7 & 42,5 & 24,5 & $7,12 \times 10^{-6}$ & $A-7-6$-axgi.loso \\
\hline & $\mathrm{b}$ & $60-80$ & 97,4 & 75,5 & 50,1 & 53,2 & 28,0 & $5,36 \times 10^{-0}$ & |A-7-6-argiloso \\
\hline & $\mathrm{c}$ & $100-120$ & 97,4 & 75,0 & 50,0 & 53,0 & 28,0 & $5,30 \times 10^{-6}$ & A-7-6-argiloso \\
\hline \multirow{3}{*}{2} & $\bar{a}$ & $0-20$ & 96,0 & 80,0 & 68,0 & 64,0 & 27,0 & $3,0 \times 10^{-5}$ & $\mathrm{~A}-7-5$-argiloso \\
\hline & $\mathrm{b}$ & $60-80$ & 96,8 & 81,4 & 69,9 & 65,7 & 29,6 & $6,30 \times 10^{-5}$ & A-7-5-argiloso \\
\hline & C & $100-120$ & 97,0 & 82,0 & 70,0 & 66,0 & 30,0 & $5,0 \times 10^{-5}$ & $A-7-5-a r g i 10 s o$ \\
\hline \multirow{3}{*}{3} & $a$ & $0-20$ & 99,9 & 97,9 & 78,1 & 55,5 & 22,2 & $1,18 \times 10^{-5}$ & A-7-5-argiloso \\
\hline & $\mathrm{b}$ & $60-80$ & 100,8 & 99,0 & 93,7 & 58,5 & 21,0 & $1,20 \times 10^{-5}$ & A-7-5-argiloso \\
\hline & $c$ & $100-120$ & 100,0 & 99,0 & 93,0 & 58,5 & 21,0 & $1,20 \times 10^{-5}$ & A-7-5-argiloso \\
\hline \multirow{3}{*}{4} & a & $0-20$ & 100,0 & 99,0 & 81,3 & 57,0 & 21,4 & $1,17 \times 10^{-5}$ & $A-7-5$-argiloso \\
\hline & $\mathrm{b}$ & $60-80$ & 99,0 & 98,0 & 94,0 & 57,8 & 22,0 & $1,20 \times 10^{-5}$ & A-7-5-argiloso \\
\hline & c & $100-120$ & 99,0 & 99,9 & 93,8 & 58,3 & 22,2 & $1,20 \times 10^{-3}$ & $A-7-5$-argiloso \\
\hline \multirow{3}{*}{5} & $a$ & $0-20$ & 97,0 & 77,7 & 50,2 & 44,0 & 18,5 & $5,96 \times 10^{-6}$ & A-7-6argiloso \\
\hline & $\mathrm{b}$ & $60-80$ & 97,9 & 76,7 & 52,9 & 47,4 & 22,4 & $1,12 \times 10^{-5}$ & A-7-6-argiloso \\
\hline & c & $100-120$ & 97,9 & 76,7 & 52,9 & 47,4 & 22,4 & $1,12 \times 10^{-5}$ & $\mathrm{~A}-7-6$-argiloso \\
\hline \multirow{3}{*}{6} & $\mathrm{a}$ & $0-20$ & 97,8 & 69,0 & 43,6 & 43,0 & 21,0 & $4,60 \times 10^{-65}$ & $\mathrm{~A}-7-6$-argiloso \\
\hline & $\mathrm{b}$ & $60-80$ & 97,5 & 75,0 & 50,0 & 53,4 & 28,2 & $5,43 \times 10^{-6}$ & $A-7-6$-argiloso \\
\hline & C & $100-120$ & 97,5 & 75,5 & 50,2 & 53,2 & 28,5 & $5,43 \times 10^{-6}$ & A-7-6-argiloso \\
\hline \multirow{3}{*}{7} & $a$ & $0-20$ & 99,0 & 82,0 & 27,5 & 25,0 & 11,0 & $1,50 \times 10^{-4}$ & A-2-6-areia argilosa \\
\hline & $\mathrm{b}$ & $60-80$ & 100,8 & 91,8 & 30,0 & 26,0 & 12,0 & $1,60 \times 10^{-4}$ & A-2-6-areia argilosa \\
\hline & $\mathrm{c}$ & $100-120$ & 100,0 & 91,8 & 30,0 & 26,0 & 12,0 & $1,60 \times 10^{-4}$ & A-2-6areia argilosa \\
\hline \multirow{3}{*}{8} & $\mathrm{a}$ & $0-20$ & 96,0 & 78,0 & 70,0 & 65,0 & 26,0 & $2,8 \times 10^{-5}$ & A-7-5-argiloso \\
\hline & $b$ & $60-80$ & 96,8 & 81,0 & 70,0 & 65,8 & 29,0 & $5,20 \times 10^{-5}$ & A-7-5-argiloso \\
\hline & $\mathrm{c}$ & $100-120$ & 96,8 & 81,0 & 70,0 & 65,8 & 29,5 & $5,20 \times 10^{-5}$ & A-7-5-argiloso \\
\hline \multirow{3}{*}{9} & $\bar{a}$ & $0-20$ & 92,0 & 54,0 & 19,0 & 25,0 & 6,0 & $1,8 \times 10^{-2}$ & $\begin{array}{l}\text { A-2-4-pedregulho e } \\
\text { areia argilosa }\end{array}$ \\
\hline & $\mathrm{b}$ & $60-80$ & 91,0 & 53,0 & 18,8 & 24,0 & 5,0 & $1,5 \times 10^{-4}$ & $\begin{array}{l}\text { A-2-4-pedregulho e } \\
\text { areia argilosa }\end{array}$ \\
\hline & c & $100-120$ & 91,1 & 5 & 18,8 & 24,4 & 5,3 & $1,5 \times 10^{-4}$ & $\begin{array}{l}\text { A-2-4-pedregulho } \\
\text { e areia argilosa }\end{array}$ \\
\hline
\end{tabular}

QUADRO 4 - Características físicas relacionadas a classificação H.R.B (Highway Research Board) e indices de permeabilidade dos solos amostrados. 


\begin{tabular}{|c|c|c|c|c|c|c|c|c|c|}
\hline \multirow[t]{2}{*}{ PONTO } & \multirow[t]{2}{*}{ CAMADA } & \multirow{2}{*}{$\begin{array}{c}\text { PROEUNDI } \\
\text { DADE } \\
\text { (cm) }\end{array}$} & \multicolumn{3}{|c|}{$\begin{array}{l}\text { GRANULOMETRIA } \\
(8 \text { PASSADA })\end{array}$} & \multicolumn{2}{|c|}{\begin{tabular}{|cc} 
LIMITE DE \\
CONSISTENCIA
\end{tabular}} & \multirow{2}{*}{$\begin{array}{l}\text { PERMEABI } \\
\text { LIDADE } \\
(\mathrm{cm} / \mathrm{s}) \\
\end{array}$} & \multirow[t]{2}{*}{ CIASSSIFICAÇÃO } \\
\hline & & & $\begin{array}{c}2,00 \\
\mathrm{~mm} \\
(10)\end{array}$ & $\begin{array}{c}0,420 \\
\mathrm{~mm} \\
(40) \\
\end{array}$ & $\begin{array}{c}0,074 \\
\mathrm{~mm} \\
(200)\end{array}$ & $\begin{array}{l}I_{1} . \mathrm{I} . \\
\left(\frac{8}{8}\right)\end{array}$ & $\begin{array}{l}\text { I.P. } \\
(8)\end{array}$ & & \\
\hline \multirow{3}{*}{10} & $a$ & $0-20$ & 98,0 & 87,0 & 65,0 & 50,0 & 16,5 & $9,67 \times 10^{-5}$ & A-7-5-argiloso \\
\hline & b & $60-80$ & 99,1 & 88,2 & 66,6 & 52,0 & 18,3 & $9,60 \times 10^{-5}$ & A-7-5-argiloso \\
\hline & c & $100-120$ & 99,1 & 88,2 & 66,6 & 52,0 & 18,3 & $9,60 \times 10^{-3}$ & A-7-5-argiloso \\
\hline \multirow{3}{*}{11} & $\mathrm{a}$ & $0-20$ & 97,9 & 76,7 & 52,9 & 47,4 & 22,4 & $1,18 \times 10^{-5}$ & $\mathrm{~A}-7-6$-argiloso \\
\hline & $\bar{b}$ & $60-80$ & 99,5 & 85,4 & 59,4 & 48,4 & 22,3 & $1,60 \times 10^{-5}$ & $A-7-6$-argiloso \\
\hline & c & $100-120$ & 99,5 & 85,4 & 59,4 & 48,4 & 22,3 & $1,60 \times 10^{-5}$ & $\bar{A}-7-6$-argiloso \\
\hline \multirow{3}{*}{12} & $\mathrm{a}$ & $0-20$ & 100,0 & 100,0 & 3,6 & 0,0 & 0,0 & $1,24 \times 10^{-5}$ & A-2-4-areia siltosa \\
\hline & $\mathrm{b}$ & $60-80$ & 100,0 & 100,0 & 0,7 & 0,0 & 0,0 & $1,20 \times 10^{-3}$ & A-2-4-areia siltosa \\
\hline & C & $100-120$ & 100,0 & 100,0 & 0,8 & 0,0 & 0,0 & $1,20 \times 10^{-3}$ & A-2-4-areia siltosa \\
\hline \multirow{3}{*}{13} & $\mathrm{a}$ & $0-20$ & 100,0 & 99,0 & 6,2 & 0,0 & 0,0 & $1,18 \times 10^{-3}$ & A-2-4-areia siltosa \\
\hline & $\mathrm{b}$ & $60-80$ & 100,0 & 98,4 & 5,1 & 0,0 & 0,0 & $1,30 \times 10^{-4}$ & A-2-4-areia siltosa \\
\hline & C & $100-120$ & 100,0 & 99,0 & 6,2 & 0,0 & 0,0 & $1,18 \times 10^{-3}$ & A-2-4-areia siltosa \\
\hline \multirow{3}{*}{14} & a & $0-20$ & 100,0 & 100,0 & 3,7 & 0,0 & 0,0 & $1,38 \times 10^{-3}$ & A-2-4-areia siltosa \\
\hline & $\mathrm{b}$ & $60-80$ & 100,0 & 100,0 & 0,8 & 0,0 & 0,0 & $1,25 \times 10^{-3}$ & A-2-4-areia siltosa \\
\hline & $c$ & $100-120$ & 100,0 & 100,0 & 0,8 & 0,0 & 0,0 & $1,25 \times 10^{-3}$ & A-2-4-areia siltosa \\
\hline \multirow{3}{*}{15} & $\mathrm{a}$ & $0-20$ & 99,9 & 99,7 & 4,4 & 0,0 & 0,0 & $1,58 \times 10^{-3}$ & A-2-4-areia siltosa \\
\hline & $\bar{b}$ & $60-80$ & 100,0 & 100,0 & 1,0 & 0,0 & 0,0 & $1,20 \times 10^{23}$ & A-2-4-areia siltosa \\
\hline & $c$ & $100-120$ & 100,0 & 100,0 & 1,0 & 0,0 & 0,0 & $1,20 \times 10^{-3}$ & A-2-4-areia siltosa \\
\hline \multirow{3}{*}{16} & $\mathrm{a}$ & $0-20$ & 100,0 & 100,0 & 3,6 & 0,0 & 0,0 & $1,48 \times 10^{-3}$ & A-2-4-areia siltosa \\
\hline & $\bar{b}$ & $60-80$ & 100,0 & 100,0 & 0,7 & 0,0 & 0,0 & $1,20 \times 10^{-3}$ & A-2-4-areia siltosa \\
\hline & C & $100-120$ & 100,0 & 100,0 & 0,7 & 0,0 & 0,0 & $1,20 \times 10^{-3}$ & $A-2-4$-areia siltosa \\
\hline \multirow{3}{*}{17} & a & $0-20$ & 99,4 & 95,5 & 51,5 & 30,0 & 8,0 & $2,6 \times 10^{-4}$ & $\mathrm{~A}-4 \quad-$ giltoso \\
\hline & b & $60-80$ & 96,4 & 96,0 & 52,0 & 31,0 & 7,0 & $2,5 \times 10^{-\pi}$ & -siltoso \\
\hline & C & $100-120$ & 100,0 & 100,0 & 54,1 & 26,0 & 5,0 & $2,0 \times 10^{-4}$ & -siltoso \\
\hline \multirow{3}{*}{18} & $a$ & $0-20$ & 97,0 & 69,0 & 44,0 & 43,0 & 25,0 & $4,5 \times 10^{-6}$ & A-7-6-argiloso \\
\hline & $\bar{b}$ & $60-80$ & 96,0 & 75,0 & 50,0 & 53,0 & 27,0 & $5,0 \times 10^{-6}$ & $A-7-6$-argiloso \\
\hline & C & $100-120$ & 96,0 & 75,0 & 50,0 & 53,0 & 27,0 & $5,0 \times 10^{-6}$ & $\mathrm{~A}-7-6-\operatorname{argi} 10$ so \\
\hline
\end{tabular}

$\begin{aligned} \text { QUADRO } 4 \text { - (Continuação) - Características físicas relacionadas a } & \text { classificação H.R.B (Highway Research } \\ & \text { Board) e indices de permeabilidade dos } \\ & \text { solos amostrados. }\end{aligned}$


baixas, onde ocorre deposição dos materiais decompostos dessas rochas, os solos são espessos. Onde as declividades são elevadas, superiores a 15\%, suas espessuras variam entre 0,30-1,0 metro. Nos locais de baixas declividades, as espessuras médias ficam em torno de 3,0 metros.

No campo, foram identificados como de granulometria fina, alta resistência a seco e plásticos. As suas cores variam de vermelho amarelado a vermelho, esta última predominando nos locais próximos aos diques de diabásio. Esta característica deve-se a elevada quantidade de piroxênios nos diabásios.

A análise granulométrica efetuada para classificá-los, demonstrou que possuem mais que 43,78 de finos passando na peneira $n^{2}$ 200 (Quadro 4), que corresponde a elevados teores de argila, que variam de 308 a 548 . (Quadro 3 ).

- indice de plasticidade (I.P.) com valores superiores a 18,58 e a permeabilidade inferior a $1,60 \mathrm{x} 10^{-5} \mathrm{~cm} / \mathrm{s}$ (Quadro 4), segundo CAPUTO (1973), classifica esses solos como plásticos e impermeáveis.

Os solos argilosos $(A-7-5)$, margeam a leste a área de afloramento das rochas pré-cambrianas, e em alguns locais, onde ocorrem aluviões, sobrepõem-se a estas. Localizam-se também, sobre os colúvios, a Formação Alexandra e outras porções de depósitos aluviais indiferenciados. (Anexo 6).

Em algumas porções, quando ocorrem sobre as áreas dos pedimentos e piemontes, apresentam-se distribuídos espassadamente em pequenas dimensões e profundidades. Nesses locais as declividades são superiores a 15\%. Mais a leste, onde os colúvios se confundem com os aluviões, configurando a planicie aluvionar, e nos vales, esses solos ocupam declividades de até 158 e possuem espessuras médias de 2,0 metros. Nos outros locais da planicie aluvionar, as declividades variam de 08 - 58, e suas espessuras chegam a 2,5 metros. Sobre as colinas configuradas pela Formação Alexandra, atingem espessuras médias de 2,0 metros.

Foram identificados, no campo, como de granulometria fina, alta resistência a seco e plásticos. As cores amareladas são as mais comuns, porém, nos locais mais baixos próximos aos cursos d'água, apresentam-se acinzentados. 
Esses solos possuem teores de argila variando de 308 - 408 (Quadro 3), e a quantidade de finos que passam na peneira no 200 é superior a 57,28 . (Quadro 4).

Seus indices de plasticidade superiores a 18,38 , e permeabilidade inferior a $1,20 \times 10^{-5} \mathrm{~cm} / \mathrm{s}$, indicam serem plásticos e impermeáveis.

Os solos siltosos $(A-4)$, ocupam as partes mais baixas da área, cobrindo extensas porções de mangue. (Anexo 6).

Esses solos apresentam-se muitas vezes cobertos por água, são de cor preta, ricos em matéria orgânica. Suas espessuras são de 1,20 metros.

No campo, apresentam granulometria fina, pequena resistência a seco e baixa plasticidade.

Analisados em laboratório, possuem teores de até 5,08 de argila (quadro 3), e quantidades de finos passando na peneira no 200 superiores a 51,58. (Quadro 4).

Seus indices de plasticidade inferiores a 8,08, e permeabilidade variando de $2,0 \times 10^{-4}$ a $2,6 \times 10^{-4} \mathrm{~cm} / \mathrm{s}$ (Quadro 4), os classificam como pouco plásticos e impermeáveis.

Os solos areia argilosas $(A-2-6)$, localizam-se no extremo noroeste, no extremo sul, e dispersos nas regiões mais baixas próximos aos mangues. (Anexo 6).

Esses solos ocupam porções da planicie de restinga baixa e média, e são originados a partir de depósitos areno-silticoargilosos. Nesses locais as declividades são baixas $(08-58)$ e a espessura dos solos são em média de 2,0 metros.

Apresentam no campo granulometria grossa com finos, resistência a seco média e plasticidade média. Suas cores são pardas e próximo aos mangues tornam-se cinzas.

Os teores de argila desses solos, variam de 308 - 338 (Quadro 3), com quantidades de finos passando na peneira $\mathrm{n}^{\circ} 200 \mathrm{em}$ torno de 308 . (Quadro 4 ).

Ainda no Quadro 4, verifica-se que seus índices de plasticidade são variáveis de 11,08 - 12,08, e a permeabilidade é inferior a $1,50 \times 10^{-4} \mathrm{~cm} / \mathrm{s}$, o que os qualifica de plasticidade baixa e impermeáveis. 
Os solos pedregulhos e areias argilosas (A-2-4), dispõem-se a noroeste da área em estudo, onde afloram cascalhos, que ocupam a planície de restinga média. (Anexo 6).

Ocupam áreas planas de baixa declividade, e suas espessuras médias são de 1,50 metros.

Sua granulometria no campo é grossa com finos, a resistência a seco é pequena e a plasticidade é baixa. Suas cores são amarelo acinzentadas.

Esses solos possuem teores de argila de até 20,08 (Quadro 3), e a quantidade de finos que passa na peneira no 200 é de aproximadamente 18,88 (Quadro 4).

Apresentam indice de plasticidade variando de 5,08 - 6,08 e a permeabilidade inferior a $1,5 \times 10^{-4} \mathrm{~cm} / \mathrm{s}$, caracterizando-os como de plasticidade baixa e impermeáveis.

Os solos areias siltosas $(A-2-4)$, ocupam à maior extensão da área estudada, cobrindo grande parte da planície de restinga alta, média e baixa. (Anexo 6).

São originados de dépositos arenosos marinhos e pouco se diferenciam destes nos afloramentos.

Em alguns locais, esses solos apresentam um nível mais escuro, intercalado a níveis de cor branca. (Ponto 13, Anexo 6). Apesar da granulometria areno siltosa ser comum a todos os niveis, a porção mais escura possue maior agregação e configura-se impermeável.

Esses níveis impermeáveis, encontram-se em profundidades entre 0,60 - 1,0 metro, com espessuras de até 0,20 metro. sua ocorrência é esparsa em toda a parte baixa da planície litorânea, e supõe-se ser a matéria orgânica, a responsável pela agregação e impermeabilidade dos mesmos.

Nos locais onde ocorrem esses niveis, são comuns alagamentos, devido a sobreposição do lençol freático ou, a periodos prolongados de chuvas.

Os solos areia siltosas, demonstraram no campo, granulometria grossa com finos, baixa resistência a seco e baixa plasticidade. As cores predominantes são o branco e o amarelo, ocorrendo níveis escuros com matéria orgânica. Suas profundidades médias são de 1,50 metros. 
Nas análises granulométricas realizadas em laboratório, apresentam-se com até 28 de argila (Quadro 3), e quantidades inferiores a 6,28 de finos passando na peneira n 200 . (Quadro 4).

Seus indices de plasticidade são nulos e sua permeabilidade é superior a $1,50 \times 10^{-3} \mathrm{~cm} / \mathrm{s}$ (Quadro 4), demonstrando serem não plásticos e altamente permeáveis.

Em relação a permeabilidade, deve ser feita exceção para a camada b do ponto 13, que apresenta-se impermeável. (Quadro 4).

o p.H. de todos os solos da área estudada é ácido (Quadro 3), característica que segundo a CETESB (1985), inviabiliza o uso desses solos como material de cobertura e impermeabilização de aterros sanitários. Contudo, existem solos na região estudada, que satisfazem todas as outras condições estabelecidas pela CETESB (1985), para esse uso, excetuando-se o p.H.

Porém, esse impedimento pode ser contornado, através de uso de materiais sintéticos como propõe VAN IMPE (1995), ou aumentando o p.H. desses solos com calagens. Essa última opção, é viável, tendo em vista a grande produção de calcário para corretivo de solo, na região leste de Curitiba. o processo de calagem seria feito no local do aterro sanitário, ou em suas proximidades, escarificando-se o solo e, misturando ao mesmo o calcário. Após a retificação do p.H. para valores iguais ou superiores a 7,0 , o solo poderia ser usado para impermeabilização e cobertura do aterro sanitário.

os solos recomendados para impermeabilização e cobertura de aterros sanitários, na área estudada, após correção da sua acidez, são os solos argilosos $(A-7-6)$ e $(A-7-5)$.

Para a locação de aterros sanitários, não satisfazem as N.B.R. -8418 (A.B.N.T., 1984), N.B.R.-8419 (A.B.N.T., 1984), N.B.R.8849 (A.B.N.T., 1985), N.B.R.-10.157 (A.B.N.T., 1987) e as normas da CETESB (1983 e 1984), os solos siltosos $(A-4)$, solos pedregulhos e areias argilosas $(\mathrm{A}-2-4)$, os solos areias siltosas $(\mathrm{A}-2-4)$ e os solos areias argilosas $(A-2-6)$.

Os solos siltosos e os de pedregulho e areias argilosas, não se enquadram nas exigências do teor de argila superior a 308 e do indice de plasticidade maior que 15 unidades.

Os solos areias siltosas, são permeáveis, não apresentam teores de argila superior a $30 \%$ e seus índices de plasticidade são 
nulos, isto os desqualifica para serem $\circ$ substrato de aterros sanitários.

Os solos areia argilosa, apresentam teores de argila superior a 30,08, porém seus índices de plasticidade são inferiores a 15 unidades, fator que os desqualifica para o uso proposto.

os solos argilosos $(A-7-6)$ e $(A-7-5)$ possuem teores superiores a $30 \%$ de argila, indices de plasticidade superiores a $30 \%$ e permeabilidade inferior a $1 \times 10^{-4} \mathrm{~cm} / \mathrm{s}$, caracteristicas que os qualificam para serem substrato de aterros sanitários.

Nos solos argilosos foram observadas variações locais de pequena expressão na camada a, que configuram-se como A-6 e A-4, solos argilosos com limite de liquidez menor que os solos modais e solos siltosos, respectivamente.

Nos solos $(A-2-4)$, pedregulhos e areia argilosas, ocorrem, também na camada a, variações locais que constituem solos areia fina $(A-3)$.

Por apresentarem pequena abrangência e representação, tais variações não foram tabeladas e descritas, contudo devem ser citadas.

Essas variações superficiais, localizadas e de pequena representação, não alteram a classificação e as características desses solos. A existência dessas variações esta relacionada a processos de rejuvenecimento local nos solos argilosos, e a processos de deposição superficial nos solos pedregulhosos e areias argilosas.

5.3. Caracterização das Áeas para a Implantação de Aerros Sanitários.

Feita a caracterização do meio físico, e efetuada a discussão dos aspectos geológicos, hidrogeológicos e dos solos em relação a locação de aterros sanitários, elaborou-se um mapa com a caracterização das áreas para a implantação de aterros sanitários na região estudada.

Neste mapa estão representadas as áreas favoráveis, favoráveis com restrições e desfavoráveis para a implantação de aterros sanitários.

As áreas favoráveis, são aquelas que se enquadram nas exigências das normas anteriormente discutidas, e apresentam as características desejáveis estipuladas neste trabalho, para a 
implantação de aterros sanitários. Essas áreas possuem aquífero confinado ou semi-confinado, baixa vulnerabilidade, profundidade do nível potenciométrico superior a 2,0 metros e as características ideais de solo. Encontram-se afastados 200 metros de qualquer captação de água ou rio, e o seu acesso é facilitado.

Em alguns locais, as áreas favoráveis a implantação de aterros sanitários, encontram-se divididas por vias de acesso. Onde isto ocorre, foi estipulada uma distância mínima de 100 metros, entre a área favorável e a via de acesso. Por essa razão, em certos locais, essas áreas apresentam contornos em linha reta.

Essas áreas favoráveis à implantação de aterros sanitários, são cobertas por solos argilosos impermeáveis, com elevado indice de plasticidade. Os materiais originais desses solos, são depósitos de colúvio, sedimentos aluviais indiferenciados e granitos.

os depósitos sedimentares, configuram duas faixas extensas margeando rios, uma a oeste com direção $\mathrm{N}-\mathrm{S}$, e outra mais a leste com direção NE. (Anexo 7).

Nessas áreas não existem impedimentos para a implantação de aterros sanitários.

Os locais com granitos, restringem-se a três áreas situadas na porção central e nordeste da região estudada. Essas rochas não apresentam diáclases e não são exploradas, possuindo solos com 2,0 metros de espessura nas suas porções mais baixas.

As áreas favoráveis com restrições, possuem características de favorabilidade para implantação de aterros sanitários, porém ocorrem fatores que impedem seu uso para esse fim.

As áreas favoráveis que apresentam como restrição a presença de diáclases e ou falhas abertas, configuram locais onde os esforços tectônicos formaram sistemas de diáclases e falhas, e estas encontram-se abertas possibilitando infiltração de água ou poluentes para $\circ$ aqüífero.

Essas áreas são representadas pelas rochas pré-Cambrianas, dispostas no extremo oeste da região estudada, ou em corpos graniticos situados próximos, que afloram na planicie litorânea. Nas ilhas ocorrem rochas cristalinas diaclasadas ou falhadas, que se enquadram como favoráveis tendo como restrição a presença de diáclases e ou falhas abertas. (Anexo 7). 
Os corpos graniticos, podem apresentar pedreiras em atividade ou abandonadas, onde além das diáclases tectônicas, ocorrem diáclases geradas por explosões.

No extremo noroeste da área, ocorrem rochas da Formação Alexandra extremamente diaclasadas, que também representam essas áreas favoráveis tendo como restrição diáclases e ou falhas abertas. (Anexo 7).

Nesses locais, a deposição de residuos deve ser admitida somente após a realização de um estudo minucioso que comprove de forma inequívoca a sua viabilidade.

As áreas favoráveis com restrições devido a declividades superiores a 10\%, são configuradas pelas rochas pré-cambrianas. Essas rochas resistem aos processos intempéricos e sobressaem no relevo, gerando altas declividades. As declividades, muitas vezes são acentuadas pelas intrusões de rochas básicas do Mesozóico. Essas intrusões, na forma de diques, possibilitam o aparecimento de algumas elevações de altas declividades e formas alongadas, na área em estudo.

As declividades elevadas, podem favorecer a movimentos de massa e escorrimentos superfíciais, em épocas chuvosas. Portanto, devem ser evitadas para a implantação de aterros sanitários.

As áreas com esse tipo de restrição, ocorrem em rochas cristalinas, e situam-se na região noroeste da região estudada, ou em elevações das ilhas. (Anexo 7).

As áreas com restrição devido a baixa profundidade do nível potenciométrico, restringem-se às proximidades dos cursos d'água. (Anexo 7). Nesses locais o nivel potenciométrico inferior a 2,0 metros de profundidade, se traduz em situação de risco para a água subterrânea.

Soma-se a essa restrição, a característica dessas áreas serem argilosas, possibilitando o acúmulo de água em épocas chuvosas. Por essa razão, em alguns locais as mesmas foram dimensionadas de forma a cobrir uma extensão maior margeando os rios. (Anexo 7).

As áreas favoráveis com restrição devido ao agrupamento de cursos d'água e ou existência de poços, situam-se em uma faixa na porção oeste da região estudada, onde existem vários rios e poços. Isto dificulta a manutenção de uma distância mínima de 200 metros 
entre os mesmos e os locais para a implantação de aterros sanitários. ocorrem também, em uma pequena extensão a sudeste da área estudada. (anexo 7).

os rios que ocupam essa área, na porção oeste da região estudada, são considerados de Classe I pela portaria nํ 05/89 da SUREHMA, contudo aqueles para os quais afluem $\circ$ fluxo das águas subterrâneas, são considerados de Classe II. Classe em que se encontram enquadrados, todos os rios da planície litorânea, no local estudado.

As áreas favoráveis com restrição devido a ocupação urbana, apresentam-se em locais onde estão assentados núcleos urbanos.

Essas áreas situam-se a sudeste e nordeste do local em estudo. (Anexo 7). A sudeste é englobada pelo núcleo urbano de Praia de Leste, e a nordeste pelo núcleo urbano de pontal do sul.

A implantação de aterros sanitários dentro dos núcleos urbanos deve ser desconsiderada não só pelo impacto visual, mas também, pela possibilidade da degradação ambiental e sanitária que estes podem causar. Além desses aspectos, deve-se considerar a desvalorização imobiliária das regiões de entorno dos aterros sanitários, fator indesejável aos centros urbanos.

As áreas desfavoráveis à implantação de aterros sanitários, foram determinadas pela inadequação do meio físico às características desejáveis para esse fim, estipuladas neste trabalho.

Essas áreas cobrem a maior extensão do local estudado, e são configuradas onde afloram os cascalhos, os sedimentos areno-silticoargilosos, sedimentos arenosos marinhos e mangues. Distribuem-se ocupando praticamente toda a planície litorânea, e as maiores extensões das ilhas. (Anexo 7).

Nos locais onde afloram os cascalhos, a noroeste, os solos determinaram a inadequação da área. Os solos desse local, pedregulhos e areias argilosas, apesar de impermeáveis, apresentam quantidades inferiores a 308 de argila e indices de plasticidade inferiores a 15 unidades.

Os baixos teores de argila, implicam em baixa capacidade de absorção dos solos, aumentando a possibilidade de contaminação da água subterrânea. Os indices de plasticidade baixos, impedem que o 
solo suporte cargas elevadas sem romper-se, característica indesejável em locais para a implantação de aterros sanitários.

As áreas ocupadas pelos sedimentos areno-siltico-argilosos, distribuem-se no extremo norte, a sudoeste e nas partes baixas, próximas aos rios. (Anexo 7).

A inadequação dessas áreas, foi evidenciada pelas características dos solos, e pela situação destes no terreno.

Os solos silticos argilosos, impermeáveis, também apresentam baixos teores de argila e de indices de plasticidade, que comprometem seu uso como substrato de aterros sanitários.

A localização dessas áreas, próxima aos rios, em locais sujeitos a inundação, onde o nível potenciométrico é baixo, lhes confere caracteristica de inadequalidade para o uso em questão.

Para as áreas dos sedimentos arenosos marinhos, a maior de todas, os fatores desfavoráveis foram os solos, as características do aquífero e sua vulnerabilidade.

os solos desses locais, são do tipo areia siltosa, com baixos teores de argila e permeáveis, sendo indesejáveis para o uso proposto.

O aqüífero livre, apresenta grandes extensões de alta vulnerabilidade, o que torna sua área de ocorrência sem a mínima viabilidade para implantação de atercos sanitários.

Os mangues, estão sujeitos a inundações frequentes, e seus solos siltosos, não possuem as caracteristicas mínimas exigíveis para sustențar aterros sanitários. 
Apesar de não ser proposição deste trabalho discutir os aspectos dos impactos ambientais e sanitários, provocados com a implantação de aterros sanitários, verificou-se a necessidade em relacioná-los.

Essa preocupação reside no fato que os aterros sanitários, mesmo aqueles onde todas as medidas de proteção ambiental foram tomadas, não poderem ser considerados como locais perfeitamente individualizados do meio ambiente.

Portanto, a possibilidade de efluentes líquidos ou gasosos serem lançados para fora do aterro sanitário, deve ser considerada. Havendo desta forma, a necessidade do monitoramento constante dessas obras.

Assim, com a implantação de aterro sanitário, é de se esperar os seguintes impactos ambientais e sanitários:

- Poluição atmosférica

Durante a implantação do aterro e posteriormente durante sua operacionalidade, deve-se esperar um aumento de materiais particulados no ar, ou seja de poeira. A produção de poeira, será tanto maior, quanto for a circulação de máquinas durante a implantação e, de caminhões de coleta e transporte de residuos sólidos durante a operacionalização do aterro.

os resíduos sólidos ao serem depositados entram em decomposição produzindo fenômenos biológicos que segundo BAILEY e OLLIS (1972), podem ser classificados de acordo com a sua fonte de oxigênio em:

\section{- Processos aeróbios \\ - Processos anaeróbios}

Durante os processos aeróbios, a degradação ou a digestão da porção orgânica dos resíduos sólidos por microorganismos, produz excesso de $\mathrm{CO}_{2}$. Esse gás carbônico transporta o nitrogênio e parte do oxigênio presente. Ao final do processo, desaparece o restante de oxigênio, que é consumido pela atividade microbiana. 
Os processos anaeróbios podem ser divididos em fase ácida, metânica instável e metânica estável.

$\mathrm{Na}$ fase ácida as gorduras, proteínas e carbohidratos são transformados em ácido acético e ácido nítrico, entre outros. Nessa fase a produção de gás carbônico é máxima, aparecendo hidrogênio e resíduos de nitrogênio.

Na realização da fase metânica instável, as bactérias anaeróbias utilizam os ácidos da fase anterior, liberando metano e gás carbônico, enquanto outras se utilizam do gás carbônico formado, como receptor do hidrogênio, para formar metano e água.

$\mathrm{Na}$ fase metânica estável, a ocorrência de enxofre é praticamente nula e o gás gerado pela mistura de metano e enxofre, persiste por longos períodos.

A duração dessas fases, de acordo com FORQUAR e ROVERS (1973) citados por AISSE et al. (1982), é de dias a semanas para a fase aerobia, dois meses para fase anaeróbia ácida, dois anos para a fase anaeróbia-metânica instável e de dez anos para a fase aneróbia metânica estável.

Assim, as emanações gasosas emitidas por um aterro, dependerão do tipo de degradação que está ocorrendo no mesmo, e da fase de degradação em que se encontram os resíduos orgânicos depositados.

Portanto, em um aterro em implantação os gases gerados serão - gás carbônico em excesso e quantidades menores de metano, oxigênio e nitrogênio. Gases em sua maioria inócuos e quase inodoros.

Em depósitos de lixo a céu aberto ou em aterros manejados incorretamente, a degradação da matéria orgânica em diferentes velocidades e submetida a diferentes processos, produz uma mistura de gases com excesso de metano. Esses gases apresentam forte odor, e podem degradar a qualidade do ar, apesar de permanecerem inócuos.

Em aterros convenientemente implantados e manejados, esses gases podem ser captados e usados na produção de energia.

\section{- Poluição hídrica}

Nas diversas fases da degradação dos resíduos sólidos depositados em um aterro, ocorrem fenômenos químicos e biológicos que geram 11́quidos. 
Esses líquidos apresentam valores elevados de demanda química de oxigênio, produzindo drástica redução do oxigênio quando em contato com outro meio líquido.

$\mathrm{Na}$ composição desse líquido, chamado de chorume ou sumeiro, além da carga orgânica e inorgânica ocorrem coliformes fecais, coliformes totais, amônia e outros elementos.

A SUREHMA (1988), analisando águas do rio Passaúna, nas proximidades do depósito de Iixo da Lamenha Pequena em Curitiba, observou limites acima dos permitidos de cromo, cianetos, fenóis, demanda bioquímica de oxigênio, coliformes fecais, coliformes totais e variações na cor e turbidez. Características essas devidas a infiltração de chorume.

Portanto, tanto as águas superficiais quanto as de subsuperficie podem ser afetadas pelo chorume.

Relevante é mencionar, a possibilidade do chorume sofrer diluição, dispersão, floculação, troca iônica e filtração pelo solo, fatores que de certa forma protegem as águas subterrâneas. Contudo, em águas superficiais de pH elevado, a amônia pode se transformar em amoníaco que é extremamente tóxico à vida aquática.

o chorume, no entanto, pode ser drenado dos aterros impermeabilizados e tratado com técnicas especificas, como as expostas por IMHOFF (1966).

\section{- Impacto sanitário pela proliferação de vetores}

A proliferação de vetores, pela disposição de residuos sólidos, é o impacto potencial mais diretamente sentido pela população circunvizinha e, portanto o mais indesejável.

Entre os vetores mais comuns, estão as moscas e os roedores que apresentam alto grau de sinantropismo. Essa característica de se utilizar das condições criadas pelo homem para sobreviver, possibilita a rápida dispersão desses insetos e roedores.

A dispersão desses vetores atingem áreas consideráveis, principalmente as moscas, em direção as regiões urbanas.

Esse fato é preocupante, tendo em vista o grande número de doenças transmitidas pelas moscas e ratos, como a febre aftosa, febre tifóide, brucelose, cólera, amebiose e peste bubônica, entre outras, também graves. 
A proliferação desses animais, pode ser reduzida com a persistente e correta cobertura do lixo, por materiais impermeabilizantes. Havendo contudo, a necessidade de um controle severo da limpeza dos setores do aterro e, em caso extremo o uso de inseticidas e raticidas pela administração do aterro.

- Alterações de tráfego pela circulação de caminhões de coleta e disposição de lixo

A região circunvizinha da área onde se implanta um aterro sanitário, sofre o impacto do aumento do tráfego de caminhões de coleta e, disposição dos resíduos sólidos.

o aumento de tráfego de caminhões, pode ocasionar acidentes, congestionamento de trânsito e efeitos deletérios às vias de acesso.

Esses impactos podem ser minimizados através da ordenação de circulação e chegada dos caminhões ao aterro, colocação de sinais de tráfego e, manutenção constante das vias de acesso. 
A caracterização do meio físico e, o diagnóstico efetuado da situação da disposição dos resíduos sólidos, no município de Paranaguá, permitiram as seguintes conclusões:

- Os depósitos de resíduos sólidos em atividade no município, configuram lixões, pois os métodos de operação são precários no depósito de lixo de Shangrilá e inexistente nos outros.

- A localização dos depósitos de resíduos sólidos da ilha de Valadares, do Embocuí e de Shangrilá é inadequada, devido ao tipo de solo e vulnerabilidade do aqüífero. o solo areno siltoso permeável, apresenta pouca argila e, o aquífero é de alta vulnerabilidade.

- O depósito de lixo hospitalar de Alexandra-Matinhos, apresenta localização adequada, devido ao solo argiloso impermeável e, o aqüifero de baixa vulnerabilidade.

- Existe a necessidade da eliminação das caracteristicas de periculosidade dos residuos hospitalares, antes da disposição final.

- Os solos argilosos (A-7-5), nos locais onde a profundidade do nivel potenciométrico é superior a 2,0 metros, configuram áreas favoráveis para a implantação de aterros sanitários. Onde o nível potenciométrico é inferior a 2,0 metros, ocorrem agrupamentos de rios e ou poços, existem diáclases e ou falhas e dispõem-se assentamentos urbanos, configuram áreas favoráveis com restrições.

- Os solos argilosos (A-7-6), configuram áreas favoráveis com restriçóes, devido a diáclases e ou falhas, e declividades superiores a $10 \%$, em alguns locais. Onde não existem diáclases e falhas, e as declividades são inferiores a 108, representam áreas favoráveis para a instalação de aterros sanitários.

- Os solos argilosos (A-7-5 e A-7-6), podem ser, usados como material de cobertura dos residuos sólidos e na 
impermeabilização de aterros sanitários, após correção do seu p.H. .

- As pedreiras desativadas existentes na região municipal, demonstraram-se áreas favoráveis com restriçoes à implantação de aterros sanitários, devido a existência de diáclases e ou falhas, ou devido a declividades elevadas. A disposição de resíduos nesses locais, deve ser permitida somente após estudos acurados de avaliação do impacto ambiental, de forma a comprovar sua viabilidade.

- Os solos siltosos (A-4), areia argilosa (A-2-6), pedregulho e areia argilosa $(\mathrm{A}-2-4)$ e areia siltosa (A-24), representam áreas desfavoráveis à instalação de aterros sanitários. A razão da desfavorabilidade deve-se aos teores de argila inferiores a 308 e indices de plasticidade inferiores a 15 unidades em todos os solos, e permeabilidade elevada nos solos areia siltosa.

- Nas áreas favoráveis e favoráveis com restrições à implantação de aterros sanitários, os aqüiferos são confinados e semi-confinados com vulnerabilidade baixa e média. Nas áreas desfavoráveis os aqüíferos são semiconfinados e livres, com vulnerabilidade média e alta.

- Sendo escolhida uma das áreas favoráveis à instalação de aterros sanitários, para a disposição final de resíduos sólidos, os resultados contidos neste trabalho, devem ser complementados. Estudos para levantar as características do meio físico, meio biológico e antrópico, em escala compatível com as exigências de EIA e RIMA, devem ser executados, no local escolhido.

- A implantação de locais para a reciclagem dos resíduos sólidos, gerados nas praias e na cidade de Paranaguá, deve ser implementada pela administração municipal. Os catadores que atuam nos lixões, forneceriam a mão de obra para a reciclagem ser efetuada.

- Existe a necessidade do monitoramento constante dos depósitos de resíduos sólidos já existentes, bem como, 
daqueles que venham a ser instalados em uma das áreas favoráveis para esse fim.

- A administração municipal, com os resultados deste trabalho, poderá estabelecer um plano de gerenciamento dos resíduos sólidos para o município. Devendo para tanto, envolver a população e técnicos capacitados, na tentativa de resolver o problema do lixo urbano.

- o anexo 7, "Mapa de caracterização das áreas para a implantação de aterros sanitários da porção sul do município de Paranaguá", a nosso ver, poderá servir de base para escolha de locais adequados à disposição de rejeitos, e o trabalho como um todo, de uma metodologia de pesquisa neste assunto, de grande interesse no uso e conservação do meio ambiente. 
REFERENNCIAS BIBLIOGRÁFICAS

1. AISSE, M.M.; Obladen. N. L.; SANTOS, A. S. 1982. Aproveitamento dos resíduos sólidos urbanos. Curitiba, LHISAMA, 108 p.

2. ALMEIDA, F. F. M. de. 1981. Síntese sobre a tectônica da bacia do Paraná. In: SIMP. REG. GEOL., 3. Curitiba, 1982. Atas . Curitiba, SBG. p.1-20.

3. ANGULO, R. J. 1992. Geologia da planície costeira do Litoral do Estado do Paraná. São Paulo, 254p. Tese de doutoramento,I.G., Universidade de São Paulo.

4. ASMUS, H.E., FERRARI, A. L. 1978. Hipótese sobre a causa do tectonismo cenozoíco na região sul do Brasil. In: PETROBRÁs. Aspectos estruturais da margem continental leste e sudeste Brasil. Rio de Janeiro. p.75-88 (Série Projeto REMAC, 4).

5. ATTERBERG, A. 1911. UBER die physikalische bodenuntersuschung und uber die plastizitat der tone. Inst. Mitt. Bodenkund, v.1. p. 5 .

6. BAILEY, J. E. \& OLLIS, D. F. 1977. Biochemical engineering fundamental. In: Biological Reactors, Substrates and Products II: Mixed Microbial Populations in Applications and Natural Systems. New York. McGraw, p.683-702.

7. BASEI, M.A.S.; SIGA GR.; MACHIAVELLI, A.; MANCINI, E. 1992. Evolução tectônica dos terrenos entre os cinturões Ribeira e Dom Feliciano (PR-SC). Revista Bras. de Geociências, São Paulo, V.22.n.2. p.216-221.

8. BERNARDES, L. R. M.; GODOY, H. CORREA, A. R. 1978. O Clima no Estado do Paraná. In: IAPAR. Manual Agropecuário para 0 Estado do Raraná. Londrina, v.2. p.13-25. 
9. BERTRAM, G. E. 1969. Ensaios fundamentais dos solos para Construção, Rio de Janeiro. Ibero-americano Ltda. p.127.

10. BIGARELLA, J.J.; MOUSINHO, M.R.; SILVA, J.X. da. 1965. Pediplanos e seus depósitos correlativos no Brasil. Bol. Par. Geogr., Curitiba, n.15 e 17. p.117-151.

11. BIGARELLA, J.J.; BECKER, R.D.; MATOS, D.J. de; WERNER, A. Ed. 1978. A Serra do Mar e a porcão oriental do Estado do Paraná. Um problema de segurança ambiental e nacional. Curitiba, Gov. Par./SEPL/ADEA. 249p.

12. BULI, W.B. 1972. Recognition of alluvial fan deposits in the stratigraphyc record. In: RAMBLIN, W.K. \& RIGBY, J.K. ed. Recognition of ancient sedimentary environments. Tulsa. Soc. Ec. Paleont. Min. p.63-83. (Spec. Publ. 16).

13. CAPUTO, H. P. 1973. Mecânica dos solos e suas aplicações, Rio de Janeiro. Livros Técnicos e Científicos Ed., v.2. p.60-69.

14. CetesB - Companhia de Tecnologia e Saneamento Ambiental. 1983. Curso básico para gerenciamento de sistemas de resíduos sólidos, São Paulo. CETESB, p.250.

15. CetesB - Companhia de Tecnologia e Saneamento Ambiental. 1985. Resíduos Sólidos Industriais, São Raulo. CETESB/ACETESB, p.179.

16. COSTA, W. D. e SANTOS, A. C. 1994. A possibilidade de poluição das águas subterrâneas pelo Lixão de Muribeca. In: Congr. Bras. de Águas Subterrâneas, B. Recife, 1994. Anais. Recife, ABAS/DNPM/CPRM, p. 217-223.

17. CUSTÓdIO, E. \& LLAMAS, M. R. 1983. Hidrologia subterrânea, Barcelona. Omega, V.1. p.445-606. 
18. DAS, B. M. 1983. Advanced soil Mechanics, New York. McgrawHi1l, p.511.

19. DE BIASI, M. 1970. Cartas de declividade: confecção e utilização-geomorfologia, São Paulo, v.10.p.8-13.

20. DUARTE, V. 1980. Geologia ambiental da área de São Paulo - SP - vetor águas subterrâneas. São Paulo, 79p. Tese de doutorado. I.G. Universidade de São Paulo.

21. ELLERT, N. \& GIUSTI, D. A. 1984. Locação de um poco tubular profundo para a COCAP - Método de eletroresistividade. Curitiba. Relatório Técnico. 12p.

22. ELLERT, N.; GREENHOUSE, J.; WILLIANS, M.M.; MENDES, J.M.B.; HASSUDA S. 1986. A geofísica aplicada na identificação da poluição do subsolo por depósitos de rejeitos urbanos e industriais. In: Cougr. Bras. Águas Subterrâneas, 4. Brasilia, 1986. Anais. Brasília, ABAS, p.528-532.

23. ELLERT, N. \& ROSA Filho, E. 1988. A geofísica aplicada na deteç̧ão de lixo urbano enterrado. Exemplo: Curitiba, Paraná - Br. In: Congr. Bras. Águas subterrâneas, 5. São Paulo, 1988. Anais. São Paulo, ABAS, p.237-246.

24. ELLERT, N.; ROSS, S.; MENDES, J.M.B.; MARTIN, E. 1990. Mapeamento geofísico do Lixão de São Carlos. In: Congrs. Bras. de Águas Subterrâneas, 6. Porto Alegre, 1990. Anais. Porto Alegre, ABAS, p. 82-88.

25. EMBRAPA - Empresa Brasileira de Pesquisas Agropecuária. 1977. Levantamento de reconhecimento dos solos do litoral do Estado do Paraná (área 11). Bol. Téc. Serv. Nac. Lev. Cons. Sol., Curitiba, n.54. 1228p. 
26. ENGESPAÇO Indústria e Comércio Ltda. 1989. Manual de referência do sistema geográfico de informações - S.G.I., São José dos Campos - SP. ENGESPAÇO, 180p.

27. EOSTER, S.S.D.; HIRATA, R.C.; ROCHA, G.A. 1988. RisCOS de de poluição de águas subterrâneas: uma proposta metodológica de avaliação regional. In: Congres. Bras. de Águas Subterrâneas, 5. São Paulo, 1988. Anais. São Paulo, ABAS, p. $175-185$.

28. FUCK, R.A.; TREIN, E.; MURATORI, A.; RIVEREAU, J.C. 1969. Mapa geológico preliminar de litoral, da serra do Mar e parte do Primeiro Planalto no Estado do Paraná. Bol. Par. Geoc., Curitiba, n.27. p.123-152.

29. FUzzARO, J. 1994. Disposição de residuos sólidos em aterros sanitários. In: Evento do programa de atualização em tecnologias de interesse ambiental, 6. São Paulo, 1994. Anais. São Paulo, ABEQ/IPI, p.50-85.

30. GIUSTI, D. A. 1989. Estudo do Impacto Ambiental da Implantação do Terminal Marítmo da CATALLINE - Porto de Paranaguá. Curitiba. Relatório Técnico. V.1.50p.

31. GIUSTI, D. A. 1994. Hidrogeologia do litoral do Paraná (Região de Paranaguá). In: Exame de Qualificação a nível de doutorado. Rio Claro - SP., 1994. UNESP, P.1-23.

32. GONÇALVES, A.R.I.; BOSSOLAN, N.R.S.; ORLANDO, M.J.G. 1992 . Determinação da direção do fluxo de freativo no aterro de São Carlos. In: Congr. Bras. de Águas Subterrâneas, 7 . Belo Horizonte, 1992, Anais. Belo Horizonte - MG, ABAS, p.114118 .

33. GREENHOUSE, J.P.; WILLIANS, M.M.; ELLERT, N.; MENDES, J. M.B. 1987. Geophysical studies of ground water conts mination at two Londfills in são Paulo state. In: CONFERENCIA 
LATINOAMERICANA SOBRE HIDROLOGIA URBANA $V$ CONTAMINACION DE ACUIFEROS, 1. Cochabamba, 1987. Anais. Cochabamba, [s.m.], p. 61-65.

34. HAHNER, I. 1994. Plano diretor de resíduos sólidos da região metropolitana de São Paulo. Bol. informativo da A.B.G.E., São Paulo, no 4 p.5.

35. HEITZMANN Jr., F.J. 1994. Atexros Sanitários - Mesa redonda. Bol. Informativo da A.B.G.E., São Paulo, no 4 p. 4.

36. IAPAR - INSTITUTO AGRONÔMICO DO PARANÁ 1978. Cartas climáticas básicas do Estado do Paraná. Londrina, IAPAR. 38p.

37. IMHOEF, K. 1966. Manual de tratamento de águas residuais. São Paulo, Edgard Blücher. 226p.

38. IPARDES - INSTITUTO PARANAENSE DE DESENVOLVIMENTO ECONÔMICO E SOCIAL 1990. macrozoneamento da APA de Guaraqueçaba. Curitiba, IPARDES, 2v. 257p.

39. I.T.C.F. - Instituto de Terras e Cartografia e Florestas. 1990. Mapas do Estado do Paraná. Curitiba, governo do Estado do Paraná, Escala 1:500.000.

40. JOSÉ, C.; GIUSTI, D.A.; CAMARGO, E.C. 1994. Levantamentos geofísicos para dimensionar profundidade e fluxo das águas subterrâneas em Paranaguá - PR. In: Congres. Bras. de Águas Subterrâneas, 8. Recife, 1992. Anais. Recife, ABAS/DNPM/CPRM. p. 336-342.

41. LARACH, J.O.I. 1984. Levantamento de reconhecimento dos solos do Estado do Paraná. Bol. Pesq. EMBRAPA, Londrina, n.27. $791 p$.

42. LEITE, W.C.A. 1991. Estudo do comportamento da temperatura, pH e teor de umidade na decomposição de resíduos sólidos 
uxbanos em aterros sanitários. São Carlos, 130p. Dissertaçao de mestrado. Escola de Engenharia de São Carlos, USP.

43. IIMA, R.E. e LOPES. O.F. 1985. Evolução geológica da Formação Rio das Cobras no leste do Estado do Paraná. In: Simpósio Sul-Brasileiro de Geologia, II. Florianópolis, 1985. Anais. Florianópolis, SBG. p.53-60.

44. LIMA, M.R., de; ANGULO, R.J. 1990. Descoberta de microflora em um nível Iinhítico da Formação Alexandra, Terciário do Estado do Paraná, Brasil. Anais Acad. Bras. Ciên., Rio de Janeiro, v.62, n.4 p.357-371.

45. LOUREIRO EERNANDES, J. 1947. Contribuição à geografia da praia de leste. Curitiba, Arg. Mus. Par., v.6. p.3-44.

46. MAACK, R. 1968. Geografia física do Estado do Paraná. Curitiba, Banco BADEP, UFPR, IBPT. 350p.

47. MENDES, G.M.B. 1987. Técnicas geofísicas aplicadas no mapeamento e monitoramento de poluição e contaminação de águas subterrâneas. São Paulo, $186 \mathrm{p}$. Tese de doutorado. Universidade de são Paulo.

48. MENTE, A.; LEAL, O.; MIRANDA, G.L.F. de. 1994. Os aterros sanitários e a poluição das águas subterrâneas na região metropolitana de Recife. In: CPRM. Sistema de informações para gestão territorial da Região Metropolitana do Recife. Recife. $v .1 \mathrm{p} .1-23$.

49. MINEROPAR - MINERAIS DO PARANÁ S.A. 1989. Mapa geológico do Estado do Paraná. Brasilia. Dep. Nac. Prod. Min. (DNPM). Escala 1:650.000.

50. NIMER, E. 1977. Clima. In: FUNDAÇÃO IBGE. Rio de Janeiro, 1977. Geografia do Brasil - Região Sul. Rio de Janeiro, v.5. p. 35-79. 
51. OBLADEN, N. 1993. Estudo para coleta, transporte e disposição final dos resíduos sólidos urbanos do Município de Paranaguá. Curitiba, Relatório Técnico. 60p.

52. OLIVEIRA, G. B. de. 1972. Variação de características morfológicas físicas, químicas e minerológicas em áreas de oxissolo. Piracicaba, 198p. Tese de doutorado. Universidade de são Paulo.

53. PACHECO, A.; MENDES, G.M.B.; MARTINS, T.; HASSUDA, S.; KIMMELMANN, A.A. 1991. Cemeteries - A potential Risk to Groundwater. Wat. Sci. Tech., Great Britain, v.24. m.11.p.97-104.

54. PARISOT, E.H.; GUIGUER Jr., N.; REBOUÇAS, A.C.; CABRAL Jr., D.; DUARTE, V. 1985. Monitoramento das águas subterrâneas adjacentes no aterro sanitário de Taubaté, SP. Primeiros resultados. Bol. I.G. - USP., São Paulo, n 16. p.32-45.

55. PORTOBRÁS - EMPRESA DE PORTOS DO BRASIL S.A. 1988. Relatório de apresentação das medições meteorológicas observadas em Pontal do Sul, Paranaguá - PR, período set. 1982 a dez. 1986. Rio de janeiro, Inst. Pesq. Hidr. (INPH). 168p.

56. RICCOMINI, C.; PELAGGIA, A.V.G.; SALONI, J.C.L.; KOHNKE, M.W.; FIGUEIRA, R.M. 1989. Neotectonic activity in the Serra do Mar rift system (southeastern Brazil). Jour South Amer. Earth Scien., Great Britain, v.2, n.2. p.191-197.

57. RISSO, W.M. 1994. Consequencias da existência do "lixão" em relação à saúde pública. In: Evento do programa da atualização em tecnologia de interesse ambiental, 6 . São Paulo, 1994. Anais. São Paulo, ABEQ/IPT, p.7-21.

58. RIVEREAU; J.C.; FUCK, R.A.; MURATORI, A.; TREIN, E. 1968. Ilha do Mel, folha geológica. Curitiba, Comissão da carta Geológica do Paraná. Escala 1:70.0000. 
59. RIVEREAU, J.C.; FUCK, R.A.; MURATORI, A.; TREIN, E. 1969. Paranaguá, folha geológica. Curitiba, Comissão da Carta Geológica do Paraná. Escala 1:70.000.

60. ROCHA et al. 1992. Levantamento Geomorfológico com ênfase em solos na porção sul do tombamento da serra do Mar. Convênio 52/90 U.F.PR.-I.T.C.F., Curitiba.

61. ROHDE, G.M. 1989. Método de seleção de áreas para aterros sanitários. Bol. Téc. da CIENTEC, Porto Alegre, no 13. p.22.

62. SCHALCH, V.; LEITE, W.C.A.; JÚNIOR, W, F.; AGUIAR, E.M.; JUNIOR, J.I.F. 1992. Aterro sanitário: considerações sobre escolha do sitio, projeto, implantação, operação e monitoramento. In: Congres. Bras. de Águas Subterrâneas, 7. Belo Horizonte, 1992. Anais. Belo Horizonte, ABAS, p.123127.

63. SCUDINo, P.C.B. 1992. Avaliação hidrogeológica em área de disposição de resíduos sólidos, com risco de poluição de aqüiferos. In: Congrs. Bras. de Águas Subterrâneas, 7. Belo Horizonte, 1992. Anais. Belo Horizonte, ABAS, p.128-135.

64. SMA - Secretaria do Meio Ambiente do Estado de São Paulo. 1991. Critérios de exigências de EIA/RIMA e roteiros para sua elaboração em relação a usinas de reciclagem e ou compostagem, aterros para resíduos sólidos domiciliares e industriais e incineradores: manual de orientação. São Paulo. SMA/CETESB, 35p.

65. SUREHMA - SUPERINTENDENCIA DE RECURSOS HÍDRICOS E MEIO AMBIENTE. 1988. Relatório referente a implantação de aterro sanitário na área sul do município de Curitiba. - Anexos. Curitiba, Relatório Técnico. 50p.

66. TALTASSE, P.R. 1972. Mapas da vulnerabilidade à poluição dos lençois aqüíferos do município de Campinas - (Est. São 
Paulo). Publicação avulsa do I.G.-V.S.P.r São Paulo, n²1, p.12.

67. VAN IMPE, W.F. 1995. International Society of Soil Mechanic and Foundation Engineering - Policy and challenges of environmental geotechnics. In: Seminário Luso Brasileiro de Geotecnia. Lisboa, 1995. Anais. Lisboa, Sociedade Portuguesa de Geotecnia, p.31.

68. VETTORI, L. 1969. Métodos de análise de solos. Bol. Técnico do Min. da Agricultura. Rio de Janeiro, no 7 . p.24.

69. WATTS, R.J.; NUBLE, M.E.; STANTON, P.C. 1994. Hazardous wastes assessment, management, and minimization - Water Environment Research, U.S.A., v.66. no 4. p.435-440. 
REFERÊNCIAS DAS LEIS, PORTARIAS E NORMAS

- Lei Estadual ñ 7389 de 12/11/80.

Considera Áreas e Locais de Interesse Turístico para os fins da Lei Federal no 6513 de 20/12/77, as áreas e localidades litorâneas que especifica - Lei do Uso do solo do litoral.

- Portaxia minter no 53 de 01/03/79.

Estabelece normas aos projetos específicos de tratamento e disposição final de resíduos sólidos, bem como a fiscalização de sua implantação.

- Portaria no 05/SUREHMA, de 06/09/89.

Enquadra os cursos d'água da bacia Litorânea do Estado do Paraná.

- A.B.N.T. - Associação Brasileira de Normas Técnicas. 1984. N.B.R. -8418 .

Fixa as condições mínimas exigíveis para a apresentação de projetos de aterros sanitários de resíduos industriais perigosos - ARIP.

- A.B.N.T. - Associação Brasileira de Normas Técnicas. 1984. N.B.R. -8419 . Fixa as condições mínimas exigíveis para a apresentação de projetos de aterros sanitários de resíduos sólidos urbanos.

- A.B.N.T. - Associação Brasileira de Normas Técnicas. 1984. N.B.R. -6459 . Fixa os métodos de ensaios para a determinação do limite de Iiquidez de solos.

- A.B.N.T. - Associação Brasileira de Normas Técnicas. 1984. N.B.R. -7180 . Eixa os métodos de ensaio para determinação do limite de plasticidade de solos. 
- A.B.N.T. - Associação Brasileira de Normas Técnicas. 1985.

N.B.R. -8849 .

Fixa as condições mínimas exigíveis para a apresentação de projetos de aterros controlados de resíduos sólidos urbanos.

- A.B.N.T. - Associação Brasileira de Normas Técnicas. 1986. N.B.R. -10.006 .

Fixa os procedimentos para $\circ$ teste de solubilização de resíduos.

A.B.N.T. - Associação Brasileira de Normas Técnicas. 1987.

N.B.R. -10.004 .

Classifica os resíduos sólidos quanto aos seus riscos potenciais ao meio-ambiente e à saúde pública, para que esses resíduos possam ter manuseio e destinação final adequados.

A.B.N.T. - Associação Brasileira de Normas Técnicas. 1987. N.B.R. -10.007 .

Fixa procedimentos para amostragem de resíduos.

A.B.N.T. - Associação Brasileira de Normas Técnicas. 1987.

N.B.R. $-10 \cdot 157$.

Fixa as condições mínimas exigíveis para projeto e operação de aterros de resíduos perigosos, de forma a proteger adequadamente as coleções hídricas superficiais e subterrâneas próximas, bem como os operadores destas instalações e populações vizinhas.

- CONAMA - Conselho Nacional do Meio Ambiente. 1986.

Resolução 01 .

Estabelece as definições, as responsabilidades e os critérios básicos e diretrizes gerais para uso e implementação da avaliação do impacto ambiental.

- CONAMA - Conselho Nacional do Meio Ambiente. 1991.

Resolução 06 . 
Estabelece a desobrigação de incineração ou outro tratamento de queima dos resíduos sólidos provenientes de portos, aeroportos e postos de saúde, bem como, encaminha a responsabilidade de estabelecer normas para coleta, transporte, acondicionamento e disposição final desses resíduos aos órgãos estaduais de meio ambiente.

- CONAMA - Conselho Nacional do Meio Ambiente. 1991.

Resolução 08 .

Estabelece que fica vedada a entrada no país de materiais residuais destinados à disposição final e incineração.

- CONAMA - Conselho Nacional do Meio Ambiente. 1993.

Resolução 05 .

Classifica os resíduos sólidos gerados em portos, aeroportos, postos de saúde, terminais rodoviários e ferroviários, e estabelece a responsabilidade do gerenciamento desses resíduos para os estabelecimentos que os geraram. 













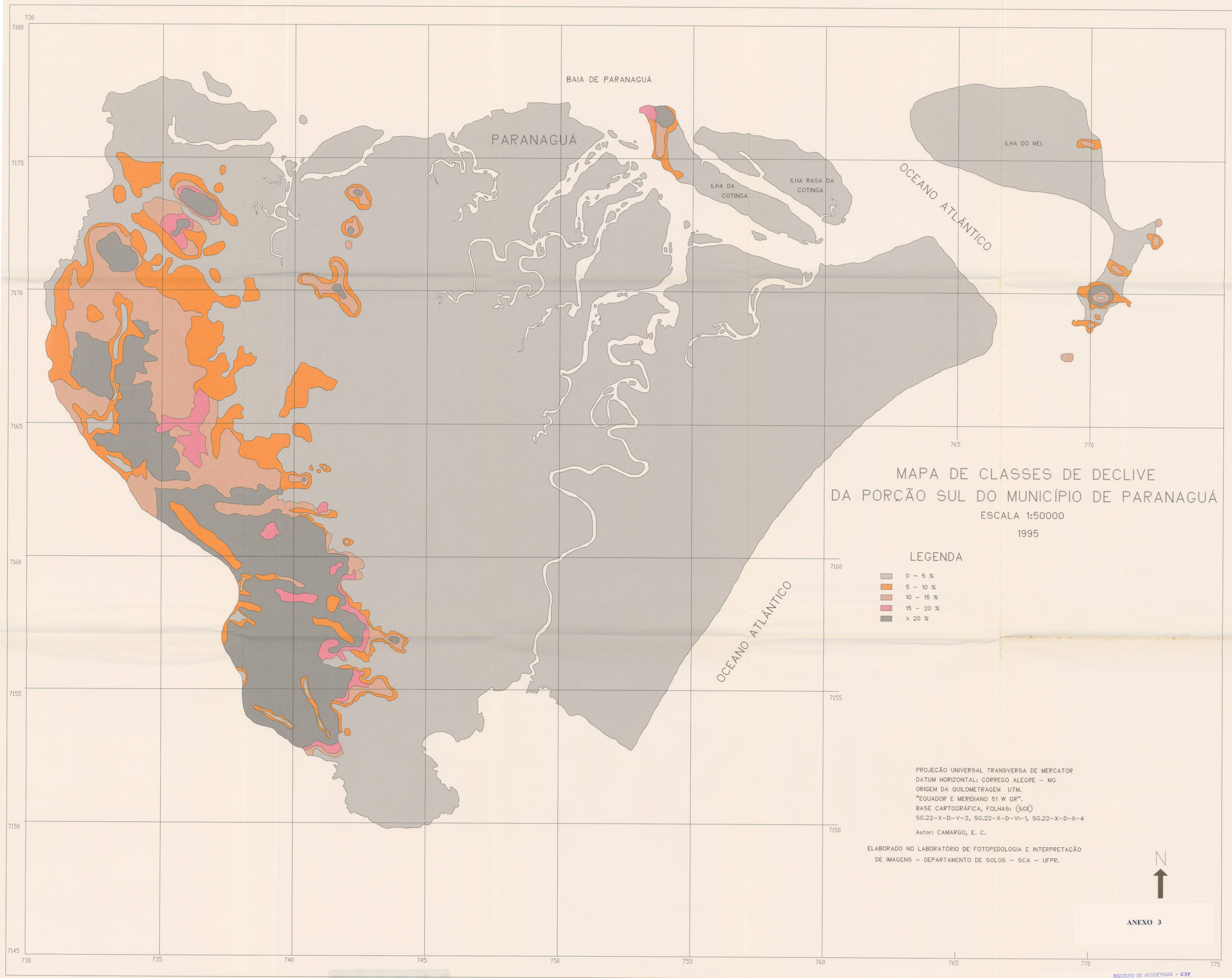











